\title{
Ground Water in the Eugene-Springfield Area, Southern Willamette Valley, Oregon
}

GEOLOGICAL SURVEY WATER-SUPPLY PAPER 2018 Prepared in cooperation with the Oregon State Engineer

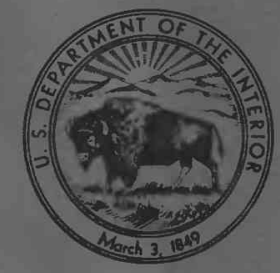




\section{Ground Water in the}

Eugene-Springfield Area, Southern Willamette Valley, Oregon

By F. J. FRANK

GEOLOGICAL SURVEY WATER-SUPPLY PAPER 2018

Prepared in cooperation with the Oregon State Engineer

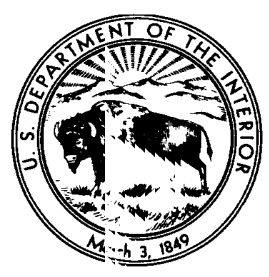

$\overline{\text { UNITED }}$ STATES GOVERNMENT PRINTING OFFICE, WASHINGTON : 1973 


\section{UNITED STATES DEPARTMENT OF THE INTERICQ}

ROGERS C. B. MORTON, Secretary

\section{GEOLOGICAL SURVEY}

V. E. McKelvey, Director

Library of Congress catalog-card No. 72-600346

For sale by the Superintendent of Documents, U.S. Government Printing Office, Washington, D.C. 20402 Price: Paper cover $-\$ 2.75$, domestic postpaid; $\$ 2.50$, GPO Bookstore

Stock Number 2401-00277 


\section{CONTENTS}

\begin{tabular}{|c|c|}
\hline & \\
\hline Introduction & 2 \\
\hline Geohydrologic system & 4 \\
\hline Topography & \\
\hline Streams and reservoirs & \\
\hline Ground-water system & \\
\hline Consolidated rocks & 10 \\
\hline Unconsolidated deposits & 10 \\
\hline Older alluvium & 10 \\
\hline Younger alluvium & 11 \\
\hline Hydrology & 11 \\
\hline Climate & 12 \\
\hline Precipitation & 12 \\
\hline Temperature & 12 \\
\hline Evaporation & 13 \\
\hline Surface water & 14 \\
\hline Streamflow & 14 \\
\hline Major streams & 14 \\
\hline Other streams & 17 \\
\hline Utilization of surface water & 18 \\
\hline Ground water & 18 \\
\hline Upland and valley-fringe areas & 19 \\
\hline West side & 19 \\
\hline East side & 21 \\
\hline South end & 22 \\
\hline Central lowland & 24 \\
\hline Occurrence and movement of ground water & 24 \\
\hline Relationship of streams to alluvial aquifers & 25 \\
\hline Transmissivity and storage coefficient & 29 \\
\hline Ground-water storage & 30 \\
\hline Storage capacity & 32 \\
\hline Changes in storage & 33 \\
\hline Replenishment of storage & 33 \\
\hline Depletion of storage & 36 \\
\hline Ground-water use & 36 \\
\hline Chemical quality of the ground water & 37 \\
\hline Explanation of quality-of-water data & 37 \\
\hline Variations in chemical quality of the water & 39 \\
\hline Suitability for use & 40 \\
\hline Ground water available for future development & 40 \\
\hline Anticipated ground-water problems & 43 \\
\hline Contamination of ground water & 43 \\
\hline Well interference & 44 \\
\hline Local overdraft & 44 \\
\hline Well construction & 45 \\
\hline
\end{tabular}


Summary and conclusions

Page

Well-numbering system

47

Basic ground-water data

49

References

50

64

\section{ILLUSTRATIONS}

[Plates are in pocket]

Plate 1. Geologic map of the Eugene-Springfield area, southern Willamette Valley, Oregon.

2. Geologic sections, Eugene-Springfield area, southern Willamette Valley, Oregon.

3. Water-level maps, September 1969 and January 1970, of the Eugene-Springfield area, southern Willanette Valley, Oregon.

Figure 1. Maps showing location and general features of the Eugene-Springfield area

Page

2-5. Graphs :

2. Annual precipitation and cumulative departure from the 1921-68 average pracipitation at Eugene

3. Combined annual streamflow of Middls Fork Willamette River at Jasper, Coast, Fork Willamette River near Goshen, and I"cKenzie River near Coburg, 1953-68 water years -..--

4. Annual streamflow of Willamette River at Harrisburg, 1953-68 water years

5. Approximate average monthly gain or loss of streamflow in the Eugene-Springfield area, 1953-68 water years

6. Map showing ground-water subareas _......... 7-10. Hydrographs:

7. Wells $16 \mathrm{~S} / 2 \mathrm{~W}-34 \mathrm{cdc},-26 \mathrm{ccc}$, and $17 \mathrm{~S} / 4 \mathrm{~W}-$ 33aba1

8. Stage of the Willamette and McKenzie Rivers, water levels in nearby wells, and daily precipitation

9. Relationship of the Willamette River stage to water levels of wells in the younger and older alluvium

10. Changes in water levels of observation wells in relation to precipitation

11. Composite hydrograph of average water levels in $\mathbf{1 5}$ observation wells showing, relationship l stween precipitation and change in ground-water storage

12. Diagram showing well-numbering system 


\section{TABLES}

TABLE 1. Principal rock units and their general hydrologic pror. erties

Page

2. Average monthly temperature and precipitation in the Eugene-Springfield area, 1921-68

3. Results of aquifer tests

4. Specific yields of materials described in drillers' $\log s$

5. Chemical analyses of water

6. Sources and significance of common chemical constituents of ground water

7. Drillers' logs of representative wells

8. Records of wells 


\title{
GROUND WATER IN THE EUGENE-SPRINGFIELD AREA, SOUTHERN WILLAMETTE VALLEY, OREGON
}

\author{
By F. J. Frank
}

\begin{abstract}
The cities of Eugene and Springfield and their outlying suburl an and rural districts constitute an area of rapid population growth where progressively greater volumes of ground water are being required for irrigation and industrial and public supplies. The area is also one of diverse geologic and hydrologic conditions.
\end{abstract}

As used in this report, the Eugene-Springfield area covers abrut 450 square miles and includes a part of the lower foothills of the Coast and Cascade Ranges and a strip of the main valley plain of the southern Willamette Valley. Volcanic and sedimentary rock units exposed in the foothills range in age from Eocene to Miocene. In the main valley plain the older units are overlain by Pleistocene and Holocene alluvial deposits. Marine-deposited sandstone, siltstone, shale, and mudstone of the older sedimentary units are fine grained and poorly permeable and yield water slowly to wells. The volcanic rocks, primarily of dacitic and andesitic composition, yield small quantities of water that are generally adequate only for domestic use. The alluvial deposits (sand and gravel) of the valley plain (central lowland) contain the most productive aquifers in the area and are considered to be the only ground-water reservoir for which large-scale development of ground-water supplies is feasible.

Aquifers in the area are recharged principally by direct infiltration of precipitation. Most of the precipitation, which averages about 40 inches per year, occurs during late autumn and winter. Minimum recharge by infiltration of precipitation to the alluvial aquifers beneath the valley plain is estimated to be about 100,000 acre-feet. Ground water is discharged naturally from the central lowland by seepage and spring flow to small streams, by subsurface outflow to adjacent areas, and by evapotranspiration.

Storage capacity of the central lowland in the Eugene-Springfield area is estimated to be about 2.1 million acre-feet in the zone 10-150 fect below land surface. The quantity of ground water available annually from this area is far greater than the 23,000 acre-feet pumped for all uses in 1968 . This pumpage was about 23 percent of the perennial yield $(100,000$ scre-ft $)$, and about 77,000 acre-feet of water was left available for additional withdrawal. If annual withdrawals of water were increased to 100,000 acre-feet 
per year, the levels in the ground-water reservoir would be lowered. Once new equilibriums are established, increased withdrawals could be accommodated without progressive losses in aquifer storage or excessive losses in flow of the larger streams.

Ground water from the alluvial deposits of the valley plain is chemically suitable for irrigation and other uses, as is most of the water ohtained from perched-water bodies in the sedimentary and volcanic rocks. However, the mineral content of water from the older sedimentary rocks, particularly from deeper producing zones, is greater than the mineral content of water from the alluvial deposits. Locally, some of the water from the older rocks is too saline for most uses.

Increased use of ground water may result in certain problems pertaining to waste-disposal practices, local overdraft of aquifers, well interference, and well construction. Present data are adequate to evaluate some of the factors relating to foreseeable problems but allow only tentative conclusions to be drawn about other factors, which include local direction of flow, rate of ground-water movement, and areas of possible ground-water contamination. Additional information obtained through systematic study will be needed to deal with these problems.

\section{INTRODUCTION}

In recent years, withdrawal of ground water for irrigation and industrial, domestic, and public supplies has increased progressively in the Eugene-Springfield area. The largest increase in groundwater withdrawal has been for irrigation. The volume of ground water used for public and domestic supplies can be expected to increase as the rural and suburban population increases; in turn, the growing population can be expected to attract industries which will require still more water.

Because of the many different geologic and hydrologic conditions in the area, the occurrence, quality, and availability of ground water vary considerably from place to place.

The purpose of this report is to present sufficient geologic and hydrologic data to aid in future development of ground-water supplies. This investigation (1) delineates the surface-subsurface geohydrologic system, (2) determines the sources, occurrence, availability, and movement of ground water, (3) determines chemical quality of the ground water, and (4) estimates the quantity of ground water used and the quantity available from the central lowland for further development.

The area covered by this investigation consists of approximately 450 square miles and lies between long $122^{\circ} 52^{\prime} 30^{\prime \prime} \mathrm{W}$. on the east, long $123^{\circ} 22^{\prime} 30^{\prime \prime} \mathrm{W}$. on the west, lat $44^{\circ} 00^{\prime} \mathrm{N}$. on the south, and lat $44^{\circ} 15^{\prime} \mathrm{N}$. on the north (fig. 1). It includes that part of the southern Willamette Valley between about Marcola on t]'e east and 


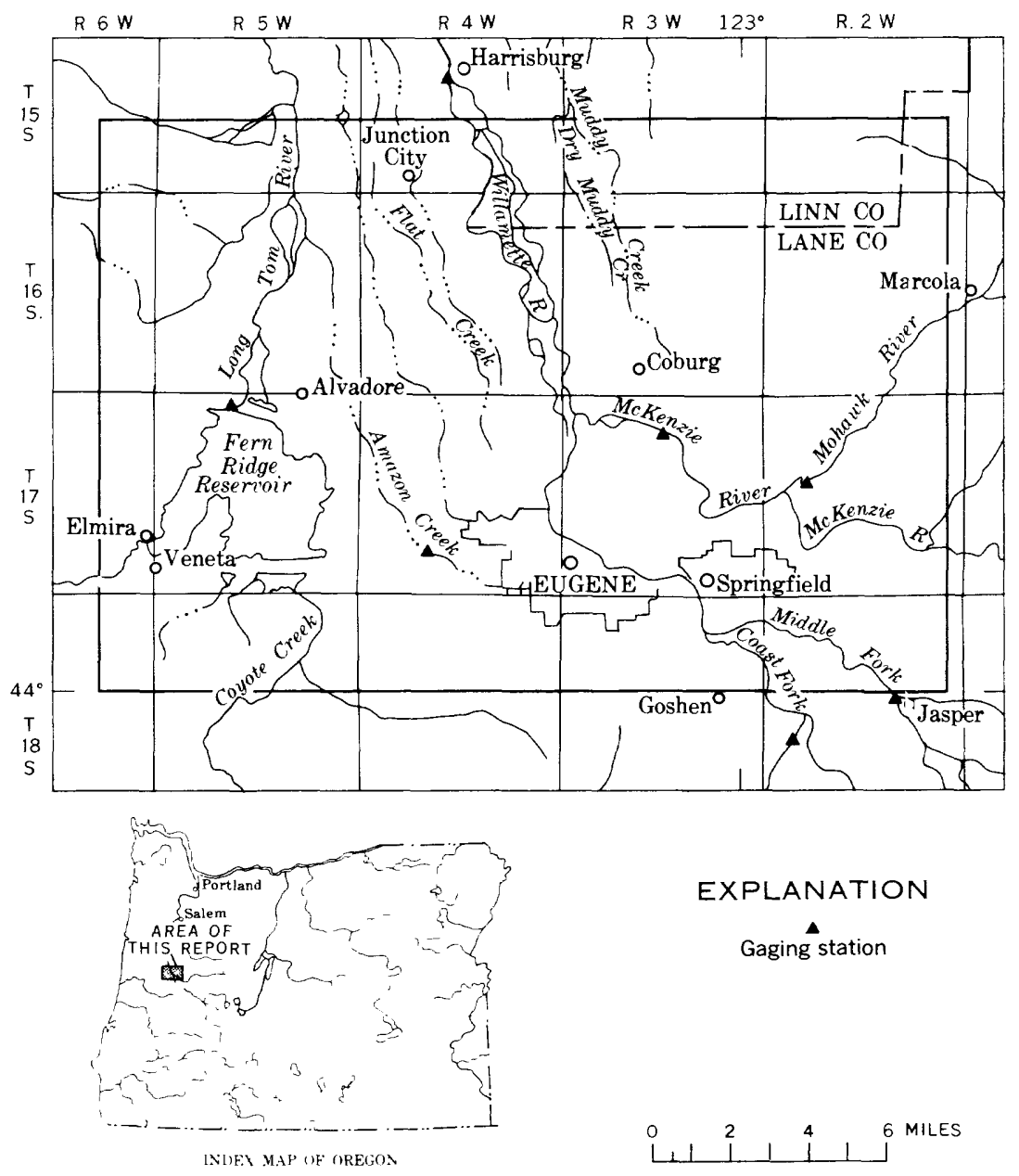

Figure 1.-Location and general features of the EugeneSpringfield area.

Elmira on the west and extends northward from Eugene to about 1.5 miles north of Junction City.

The largest cities within the study area are Eugene, population 76,346, and Springfield, population 26,874 (1970 census). Possibly an additional 30,000 people live in the suburbs of the EugeneSpringfield metropolitan area. Other incorporated cities and towns in the area, in order of their preliminary 1970 populations, are Junction City $(2,345)$, Veneta $(1,362)$, and Coburg $(65 \varepsilon)$. The major industries in the area are related to forest products and range from lumber production to the manufacture of wocd prod- 
ucts. Other nonagricultural industries of importanc? are food processing and gravel mining. Agriculture is another major occupation of the area, and in 1968 about 17,000 acres of lanc was under irrigation, 13,000 acres of which was irrigated with ground water pumped from wells.

A description of the ground-water resources of the area is included in a reconnaissance report on the ground-water resources of the Willamette Valley by Piper (1942). Also, a brief description of ground-water conditions and availability is given in a report (Frank and Johnson, 1970) that presents many of the groundwater data collected during this investigation. Records of groundwater levels for a number of wells in the study area have been collected by the Oregon State Engineer, and some of these records have been published in the State Engineer's ground-water report series (Sceva and DeBow, 1965, 1966; Bartholomew and DeBow, 1967).

This investigation is part of a continuing cooperative program between the Oregon State Engineer and the U.S. Geological Survey to evaluate the ground-water resources of Oregon. The study was made under the immediate supervision of D. D. Harr:s, chief of the Hydrologic Investigations Section, and under the general supervision of Stanley F. Kapustka, district chief in charge of U.S. Geological Survey water-resources investigations in Oregon. At various times the author was assisted in the collection and compilation of field data by E. A. Oster, S. W. Anderson, A. H. Gonsalves, and R. W. Childreth, as well as personnel of the Eugene Subdistrict office of the U.S. Geological Survey. The author extends appreciation to Gene McGinnis, assistant watermaster, district 2, for providing information and assistance in the field. Many of the data for this investigation were supplied by well owners, operators, and drillers. The helpful cooperation of these people and of the well owners who permitted access to their wells to collect ground-water data is gratefully acknowledged. Special thanks are extended to officials of the Pacific Power \& Light Co., Eugene Water \& Electric Board, Blachly-Lane County Cooperative Electric Assoc., and Lane County Electric Coop., who provided data needed to estimate the volume of ground water pumped for irrigation in the area.

\section{GEOHYDROLOGIC SYSTEM}

Water in the Eugene-Springfield area occurs in the streams that drain the area and in the alluvial deposits and consolidated rocks that underlie the area. The streams are the surface part of the geohydrologic system. The alluvial deposits and consolidated rocks 
form the subsurface, or ground-water, part of the system. The surface and subsurface parts are hydraulically interconnected, and water moves from one part to the other in response to natural and manmade gradients. This report is concerned primarily with the recovery of ground water from the subsurface part of the geohydrologic system.

\section{TOPOGRAPHY}

The Eugene-Springfield area is in the upper Willamette River basin in that part of west-central Oregon that lies between the Coast and Cascade Ranges in the Pacific Border physiogaphic province (Fenneman, 1931, p. 449).

The central part of the study area consists of an alluvial plain, and the hills make up the rest of the area. Most of the level or relatively level land is in the alluvial plain and ranges in elevation from about 450 feet above mean sea level at the southern end to about 325 feet above mean sea level at the northern end. T"e upland and valley fringe, which lie south, west, and east of the alluvial plain, are areas of gently rolling to moderately rough topography; the elevations in the ridges north and east of Coburg exceed 2,000 feet above mean sea level.

\section{STREAMS AND RESERVOIRS}

The Middle and Coast Forks of the Willamette River comkine at the southern end of the study area, near Eugene, to form the Willamette River main stem. A 25-mile reach of the main stem of the Willamette River flows through the central part of the F $^{\text {*oject }}$ area. The McKenzie River meanders through the southesstern part of the project area and flows into the Willamette River near Coburg at Willamette River mile 174.8 (Columbia Basin InterAgency Committee, 1963, p. 8), about 12 river miles north of the confluence of the Middle and Coast Forks of the Willamette River.

A few intermittent streams flowing parallel to the Willemette River drain the flatlands of the main valley plain. Amorg the largest of these streams are Amazon and Flat Creeks on the west side of the Willamette River and Dry Muddy Creek, tributary to Muddy Creek, on the east side. Flat Creek enters the Willamette north of the study area.

The upland parts of the west side of the Willamette River are drained by the Long Tom River; the upland parts of the east side of the Willamette are drained by Muddy Creek, which is als? used to convey irrigation water diverted from the McKenzie River. Other parts of the east-side uplands are drained by the Mohawk 
River, which flows through a narrow alluvial valley and is tributary to the McKenzie River near Springfield. The Long Tom River and Muddy Creek enter the Willamette north of the study area.

Flow of the Willamette and McKenzie Rivers is regulated by several reservoirs upstream from the study area. The flow of the Long Tom River is regulated by Fern Ridge Reservoir, the only reservoir in the project area. It covers about 15 squar? miles and has a storage capacity of about 110,000 acre-feet. Water stored in the reservoir includes runoff from the Long Tom River basin and also some water diverted from Amazon Creek in the SE $1 / 4$ sec. 29, T. 17 S., R. 4 W. Most of the water stored originates outside the study area.

Because flow of the principal streams in the study area is controlled by reservoirs, the rise and fall in levels of these streams do not always coincide with the precipitation pattern or with the natural fluctuation of ground-water levels. Water is normally released from the reservoir in late summer and early fall, and a low reservoir level is maintained to allow storage capacity for anticipated winter and spring runoff. As a result of reservoir operation, regulated streams have a different fluctuation pettern from unregulated streams. When water is released from reservoirs, stages of regulated streams may rise considerably higher than stages of adjacent unregulated streams. However, when storm runoff is being stored in reservoirs, stages of regulated streams may be nearly constant although unregulated streams are rising rapidly. (See section on "Relationship of Streams to Alluvial Aquifers.")

\section{GROUND-WATER SYSTEM}

The ground-water system of the Eugene-Springfield area consists of unconsolidated deposits and consolidated rocks. The unconsolidated deposits form the valley fill and are porous and transmit water readily. The consolidated rocks in the upland parts of the area yield small quantities of water to wells, but such rocks at depth beneath the valley fill have low porosities and therefore do not readily transmit water to wells. Most of the ground water pumped in the area is from the unconsolidated deposits, and the water-bearing characteristics of these deposits are described later.

The rock units that make up the ground-water system are described briefly in table 1. Distribution of these unit;, compiled from Peck, Griggs, Schlicker, Wells, and Dole (1964), Vokes, Snavely, and Meyers (1951), and Piper (1942), is shown on plate 1. 
TABLE 1.-Principal rock units and their general hydrologic properties

\begin{tabular}{|c|c|c|c|c|c|c|}
\hline Age & & $\begin{array}{c}\text { Unit } \\
\text { designation }\end{array}$ & $\begin{array}{c}\text { Approximate } \\
\text { thickness } \\
\text { (feet) }\end{array}$ & Lithology & Occurrence & General hydrologic properties \\
\hline Holocene & 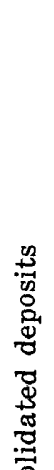 & $\begin{array}{l}\text { Younger } \\
\text { alluvium. }\end{array}$ & 35 & $\begin{array}{l}\text { Largely coarse gravels } \\
\text { and cobbles as large as } \\
6 \text { inches in diameter. } \\
\text { Contains some sandy } \\
\text { zones and a small pro- } \\
\text { portion of silt. }\end{array}$ & $\begin{array}{l}\text { Forms the flood plains } \\
\text { adjacent to the McKen- } \\
\text { zie and Willamette } \\
\text { Rivers. }\end{array}$ & $\begin{array}{l}\text { In most places, generally } \\
\text { yields large quantities } \\
\text { of water to wells pro- } \\
\text { vided (1) a sufficient } \\
\text { thickness of water-bear- } \\
\text { ing materials is present } \\
\text { or (2) the deposits are } \\
\text { pervious and are in } \\
\text { buried channels having } \\
\text { continuity with present } \\
\text { streams to allow infil- } \\
\text { tration of water from } \\
\text { streams. }\end{array}$ \\
\hline $\begin{array}{l}\text { Pleistocene } \\
\text { and Holo- } \\
\text { cene. }\end{array}$ & 号 & $\begin{array}{l}\text { Older } \\
\text { alluvium. }\end{array}$ & $20-250$ & $\begin{array}{l}\text { Sand and gravel inter- } \\
\text { spersed with mixtures } \\
\text { of sand, silt, and clay. } \\
\text { Forms lenticular bodies } \\
\text { of gravel and sand that } \\
\text { seem to be intercon- } \\
\text { nected and allow free } \\
\text { movement of ground } \\
\text { water. Deposit tends to } \\
\text { be of finer materials } \\
\text { than younger alluvium. }\end{array}$ & $\begin{array}{l}\text { Forms and lies beneath } \\
\text { the main valley plain } \\
\text { and foothills of the up- } \\
\text { land parts of the area. } \\
\text { Includes some younger } \\
\text { alluvial deposits along } \\
\text { the Long Tom River } \\
\text { and other s m a lle r } \\
\text { streams in the area and } \\
\text { also some terrace de- } \\
\text { posits in the southwest- } \\
\text { ern part of the area. }\end{array}$ & $\begin{array}{l}\text { Yields moderate to large } \\
\text { quantities of water to } \\
\text { wells in the valley plain. } \\
\text { Deposits along the Long } \\
\text { Tom River and smaller } \\
\text { streams and terrace de- } \\
\text { posits in the southwest- } \\
\text { ern part of the area are } \\
\text { composed l a g e ly of } \\
\text { fine-grained materials } \\
\text { and yield water slowly } \\
\text { to wells. }\end{array}$ \\
\hline
\end{tabular}


TABLE 1.-Principal rock units and their general hydrologic properties-Continued

\begin{tabular}{|c|c|c|c|c|c|c|}
\hline Age & & $\begin{array}{c}\text { Unit } \\
\text { designation }\end{array}$ & $\left\{\begin{array}{c}\text { Approximate } \\
\text { thickness } \\
\text { (feet) }\end{array}\right.$ & Lithology & Occurrence & General hydrologic properties \\
\hline $\begin{array}{l}\text { Oligocene } \\
\text { and Mio- } \\
\text { cene. }\end{array}$ & \multirow{3}{*}{ 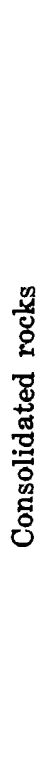 } & $\begin{array}{c}\text { Little Butte } \\
\text { Volcanic } \\
\text { Series. }\end{array}$ & $\begin{array}{r}5,000- \\
10,000\end{array}$ & $\begin{array}{l}\text { Consists of a sequence of } \\
\text { volcanic rocks, predomi- } \\
\text { nantly dacitic and an- } \\
\text { desitic flows and tuffs } \\
\text { and olivine basalt flows; } \\
\text { some scoriaceous ma- } \\
\text { terial. }\end{array}$ & $\begin{array}{l}\text { Comprises the u pland } \\
\text { parts of the area east } \\
\text { of Coburg and north } \\
\text { and east of Springfield. } \\
\text { Basalt flows occur south } \\
\text { and east of Eugene. }\end{array}$ & $\begin{array}{l}\text { Yields only small quanti- } \\
\text { ties of water to wells. } \\
\text { Most water is obtained } \\
\text { from small saturated } \\
\text { zones perched above the } \\
\text { regional water table. } \\
\text { Basalt flows yield little } \\
\text { or no water to wells. }\end{array}$ \\
\hline $\begin{array}{l}\text { Oligocene } \\
\text { or } \\
\text { younger. }\end{array}$ & & $\begin{array}{c}\text { Intrusive } \\
\text { rocks. }\end{array}$ & -------- & $\begin{array}{l}\text { Dikes and sills of diabasic } \\
\text { and basaltic composi- } \\
\text { tion. }\end{array}$ & $\begin{array}{l}\text { Numerous dikes and sills } \\
\text { intruded into sandstone } \\
\text { beds in the northwestern } \\
\text { part of the area. Similar } \\
\text { igneous masses occur in } \\
\text { the vicinity of Eugene. }\end{array}$ & Yield no water to wells. \\
\hline Oligocene & & $\begin{array}{l}\text { Eugene } \\
\text { Fomma- } \\
\text { tion. }\end{array}$ & 15,000 & $\begin{array}{l}\text { M a r i n e-deposited sedi- } \\
\text { ments of fine-to coarser } \\
\text { grained arkosic micace- } \\
\text { ous sandstone, inter- } \\
\text { calated shale, and oc- } \\
\text { casional lenses of fine } \\
\text { volcanic ash. }\end{array}$ & $\begin{array}{l}\text { Forms much of the foot- } \\
\text { hill area in the vicinity } \\
\text { of Eugene and Coburg. }\end{array}$ & $\begin{array}{l}\text { Generally yields only small } \\
\text { quantities of water to } \\
\text { wells. }\end{array}$ \\
\hline
\end{tabular}




\begin{tabular}{|c|c|c|c|c|c|c|}
\hline $\begin{array}{l}\text { Eocene and } \\
\text { Oligo- } \\
\text { cene. }\end{array}$ & \multirow{3}{*}{ 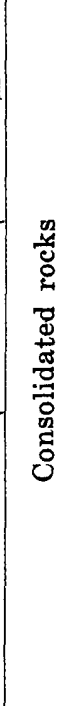 } & $\begin{array}{l}\text { Fisher } \\
\text { Forma- } \\
\text { tion. }\end{array}$ & 7,000 & $\begin{array}{l}\text { Largely tuff and breccia; } \\
\text { includes large amounts } \\
\text { of basaltic and rhyolitic } \\
\text { debris. }\end{array}$ & $\begin{array}{l}\text { Occurs in the foothills } \\
\text { west of Eugene. }\end{array}$ & $\begin{array}{l}\text { Yields small quantities of } \\
\text { water to wells. Much of } \\
\text { the water from thi } \\
\text { formation contains ex } \\
\text { cessive a mounts of } \\
\text { arsenic. }\end{array}$ \\
\hline & & $\begin{array}{l}\text { Spencer } \\
\text { Forma- } \\
\text { tion. }\end{array}$ & 2,500 & $\begin{array}{l}\text { A marine sequence of } \\
\text { tuffaceous sandstone, } \\
\text { shale, and mudstone. In } \\
\text { places intruded by igne- } \\
\text { ous rocks. }\end{array}$ & $\begin{array}{l}\text { Occurs in the foothills } \\
\text { south and northwest of } \\
\text { Fern Ridge Reservoir. }\end{array}$ & $\begin{array}{l}\text { Yields only small quanti } \\
\text { ties of water to wells } \\
\text { Water f r o m deeper } \\
\text { wells is too saline local } \\
\text { ly for most uses. }\end{array}$ \\
\hline Eocene & & $\begin{array}{l}\text { Tyee } \\
\text { Forma- } \\
\text { tion. }\end{array}$ & 5,000 & $\begin{array}{l}\text { Marine sandstone beds } \\
\text { interbedded with silt- } \\
\text { stone and mudstone. In } \\
\text { places intruded by igne- } \\
\text { ous rocks. }\end{array}$ & $\begin{array}{l}\text { Forms the upland areas in } \\
\text { the western part of the } \\
\text { area. }\end{array}$ & $\begin{array}{l}\text { Generally yields water } \\
\text { slowly to wells. Water } \\
\text { is of poor chemica } \\
\text { quality locally. Most } \\
\text { water is obtained from } \\
\text { small saturated zones } \\
\text { perched above the re- } \\
\text { gional water table. }\end{array}$ \\
\hline
\end{tabular}




\section{CONSOLIDATED ROCKS}

The consolidated rocks in the area are of sedimentary and volcanic origin. Sedimentary marine rocks are the oldest in the area and consist of sandstone, mudstone, siltstone, shale, and waterlaid volcanic ash. They form the Coast Range foothills and are exposed in the upland and valley-fringe parts of the area south and east of the main valley plain. The rocks there are generally fone grained and so compact that they yield little water to wells. Some of the water is of poor chemical quality, and in some places water from the marine sandstone and shale is too saline for most uses.

Volcanic intrusive rocks, principally diabasic and basaltic, yield little water, and the basaltic flows south of Eugene are poor aquifers. The volcanic rocks of the Little Butte Volcanic Series are primarily dacitic and andesitic and contain tuff and rhyolitic and basaltic flows. (See table 1.) They form the foothills of the Cascade Range north and south of Springfield and yield litt'e water to wells.

\section{UNCONSOLIDATED DEPOSITS \\ OLDER ALIUVIUM}

Older alluvium underlies the main valley plain and together with the younger alluvium forms the principal aquifer in the area. To a depth of at least 100 feet below the land surface, the deposit is composed of interconnected lenses of coarse volcanic sand and gravel interspersed with fine sand and silt that yield larre quantities of water to wells. Below a depth of about 100 feet, the coarser alluvial deposits grade into and interfinger with lenses of sand, silt, clay, and pebbles. Although the materials in the lower part of the alluvium have a lower permeability than do the coarser parts of the deposits, they would probably yield moderate to large quantities of water to carefully constructed wells equipped with properly designed and fabricated well screens.

The older alluvium varies considerably in thickness because of the irregularity of the erosional surface upon which it lies. Its thickness, as shown by the geologic sections (pl. 2), ranges from a featheredge at the valley margins of the upland areas to as much as 300 feet near Coburg. The average depth of the alluvium in the central part of the main valley plain probably exceeds 150 feet. Much of the alluvium has been deposited along the lower stretch of the McKenzie River to form the Springfield delta. Ir this part of the area, the deposits have a thickness of at least 200 feet (table 8 , well $17 \mathrm{~S} / 2 \mathrm{~W}-31$ bec2). 


\section{YOUNGER ALLUVIUM}

The younger alluvium is coextensive with the flood plains of the Willamette and McKenzie Rivers and contains materials that in most places sustain large withdrawals of water from wells. The flood-plain alluvial deposits are composed of cobbles, coarse gravel, sand, and a small proportion of silt. These deposits vary in character, and they range in thickness from a few feet along tre outer margins of the flood plain to 35-40 feet near the rivers.

At a few places (probably fewer than 10 percent of the total outcrop area), the younger alluvial deposits contain so much silt and clay that the deposits yield water slowly to wells. Altho'igh not extensive, these deposits locally impede the infiltration of water from the river which is necessary to sustain large withdrawals. As discussed in "Relationship of Streams to Alluvial Aquifers," in places the occurrence and availability of water from the younger alluvium is related to the flow of the McKenzie and Willamette Rivers.

\section{HYDROLOGY}

Precipitation is the source of all water in the study area. Surface water is water in streams, ponds, and lakes; ground water is water, other than soil moisture, beneath the land surfacs. Flow from a spring is ground water before it leaves the spring orifice and surface water after it leaves the orifice.

Precipitation on the land surface is absorbed by the soil unless the rate of precipitation exceeds the rate at which the soil will accept it. Precipitation that does not infiltrate flows overland as runoff to stream channels. Water that infiltrates the soil in excess of the ability of the soil to hold it by capillary attraction continues to move downward to the zone of saturation. A body of saturated material that yields water in sufficient quantity to be used as a water supply is called an aquifer. Water moves downgradient through the aquifer and is discharged naturally to strerms and springs or artificially to wells or is lost to the atmosphere by evaporation and transpiration.

The upper surface of a zone of saturation is the water te.ble, and the water in the zone of saturation is ground water. The water table is regionwide, but other water tables of minor extent may occur where "perched" ground water collects above poorly permeable materials above the main water table. Perched-water bodies in the study are generally yield only small quantities of water to wells because the volumes of recharge and of water in storage are usually limited. 


\section{CLIMATE}

The area has a temperate marine climate characterized by wet winters and dry summers. Topography, nearness to the Pacific Ocean, and exposure to middle-latitude westerly winds are the principal climatic controls.

\section{PRECIPITATION}

The average annual precipitation in the Eugene-Springfield area is about 40 inches, most of which occurs as rain. Tre wettest months of the year are November through January, during which about 45 percent of the average annual precipitation occurs. In July and August normal precipitation is less than half an inch, and occasionally in midsummer no rain occurs for periods of 30-60 days. The average monthly and annual precipitation at Eugene for the period 1921-68 is shown in table 2.

\begin{tabular}{|c|c|c|}
\hline Month & $\begin{array}{c}\text { Temperature } \\
(\circ \mathrm{F})\end{array}$ & $\begin{array}{l}\text { Precipitation } \\
\text { (inches) }\end{array}$ \\
\hline $\begin{array}{l}\text { January } \\
\text { February } \\
\text { March } \\
\text { April } \\
\text { May } \\
\text { June July } \\
\text { August } \\
\text { September } \\
\text { October } \\
\text { November } \\
\text { December - Average annual }\end{array}$ & $\begin{array}{l}39.1 \\
42.6 \\
46.0 \\
50.8 \\
56.1 \\
60.9 \\
66.6 \\
65.9 \\
61.5 \\
53.2 \\
45.5 \\
41.8 \\
52.5\end{array}$ & $\begin{aligned} \mathbf{6 . 3 3} \\
\mathbf{4 . 9 7} \\
4.32 \\
2.38 \\
2.14 \\
1.42 \\
.27 \\
.40 \\
\mathbf{1 . 2 7} \\
\mathbf{3 . 8 3} \\
\mathbf{5 . 6 2} \\
\mathbf{6 . 6 1} \\
\mathbf{3 9 . 5 6}\end{aligned}$ \\
\hline
\end{tabular}

Figure 2 shows the annual precipitation and long-term trends for the period 1921-68. The long-term trends are shown by a curve of cumulative departure from average precipitation for the 48year period. The wettest year at Eugene during 1921-68 was 1964, when 57.95 inches of precipitation was recorded, 20.99 inches of which was recorded in December. The driest year during this period was 1944, when 23.95 inches of precipitation was recorded.

\section{TEMPERATURE}

According to National Weather Service records, the average annual temperature for the area is $52.5^{\circ} \mathrm{F}$. January is gererally the coldest month, the average temperature being $39.1^{\circ} \mathrm{F}$. The lowest temperature recorded at Eugene was $-4^{\circ} \mathrm{F}$ on December $24,1924$. July is usually the warmest month, the average temperature being $66.6^{\circ} \mathrm{F}$. The highest recorded temperature was $104^{\circ} \mathrm{F}$ on July 10 , 


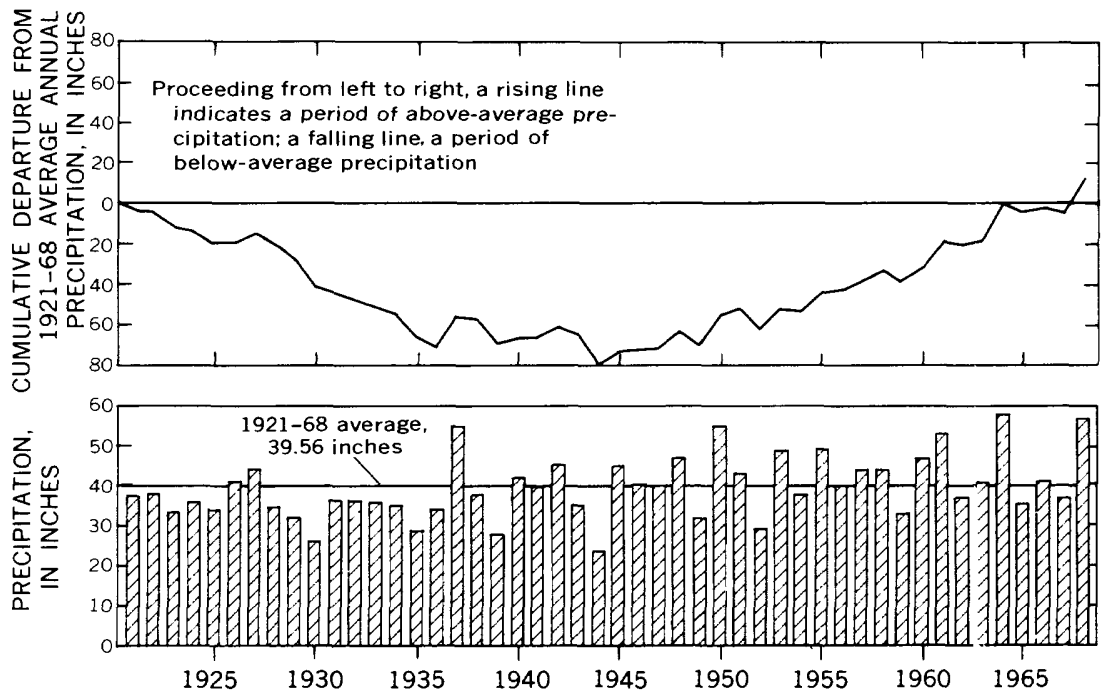

Figure 2.-Annual precipitation and cumulative departure from the 192168 average precipitation at Eugene. (Data from Natl. Weather Service.)

1926. The average monthly minimum and maximum temperatures at Eugene are, respectively, about $34^{\circ} \mathrm{F}$ for January and about $82^{\circ} \mathrm{F}$ for July.

\section{EVAPORATION}

Evaporation data for the area are collected at Fern Ridg? Reservoir. The mean annual evaporation at this station is shown in the following table:

Average monthly and annual evaporation, in inches, at Fern Ridge Reservoir

[Data from records of Natl. Weather Service]

\begin{tabular}{|c|c|c|}
\hline Month & $\begin{array}{c}\text { Class A pan } \\
\text { evaporation }\end{array}$ & $\begin{array}{l}\text { Equivalent } \\
\text { reservoir } \\
\text { evaporation }\end{array}$ \\
\hline $\begin{array}{l}\text { January } \\
\text { February } \\
\text { March } \\
\text { April } \\
\text { May } \\
\text { June } \\
\text { July } \\
\text { August } \\
\text { September } \\
\text { October } \\
\text { November } \\
\text { December } \\
\text { Annual }\end{array}$ & $\begin{array}{r}0.34 \\
.58 \\
1.48 \\
2.84 \\
5.00 \\
5.77 \\
8.24 \\
6.88 \\
4.60 \\
1.71 \\
.52 \\
.34 \\
38.30\end{array}$ & $\begin{array}{r}0.24 \\
.41 \\
1.04 \\
1.99 \\
3.50 \\
4.04 \\
5.77 \\
4.82 \\
3.22 \\
1.20 \\
.36 \\
.24 \\
26.83\end{array}$ \\
\hline
\end{tabular}

National Weather Service evaporation data are based on records of evaporation from class A land pans. To reduce the figures to 
equivalent reservoir-evaporation values, a coefficient of $0.70 \mathrm{com}$ monly is applied to evaporation data from this type of record; accordingly, the adjusted average annual reservoir evaporation at Fern Ridge Reservoir is about 26.8 inches. As shown in the preceding table, evaporation exceeds precipitation from May through September.

The average growing season in the area is a little more than 200 days from April to September.

Basic climatic data collected at the Eugene Airport weather station include estimated potential evapotranspiration values derived by the Thornthwaite-Mather procedure (Johnsgard, 1963, p. 82). These data indicate that potential evapotranspiration in the Eugene area is about 21.7 inches per year.

\section{SURFACE WATER}

\section{STREAMFLOW}

Streamflow in or near the project area is measured st streamgaging stations maintained by the U.S. Geological Survey (fig. 1). These stations are on Coast Fork Willamette River near Goshen, Middle Fork Willamette River at Jasper, Willamette River at Harrisburg, McKenzie River near Coburg, Mohawk River near Springfield, and Long Tom River near Alvadore. Records of streamflow from October 1954 to September 1968 are also available for Amazon Creek near Eugene (discontinued station). Streanflow data used in this report are from streamflow records of the U.S. Geological Survey (1962-69).

\section{MAJOR STREAMS}

The major streams of the area are the Coast and Middle Forks of the Willamette River, the main stem of the Willamette River, and the McKenzie River. The combined streamflow of these streams (fig. 3) makes up the principal inflow of surface water to the Eugene-Springfield area. Since 1953 this combined annual surface inflow has ranged from a high of about 12.5 million acre-feet to a low of about 5.8 million acre-feet. The average arnual flow for the period 1953-68 was more than 8 million acre-feet.

Surface-water outflow from the study area is measurec' at Willamette River at Harrisburg (fig. 4), about 2 river miles downstream from the north boundary of the project area. The gener 7 pattern of outflow at the Harrisburg station is similar to the inflow pattern as shown in figure 3. However, during 1953-68, there was an indicated average annual gain of streamflow of about 5 percent through the project area. 


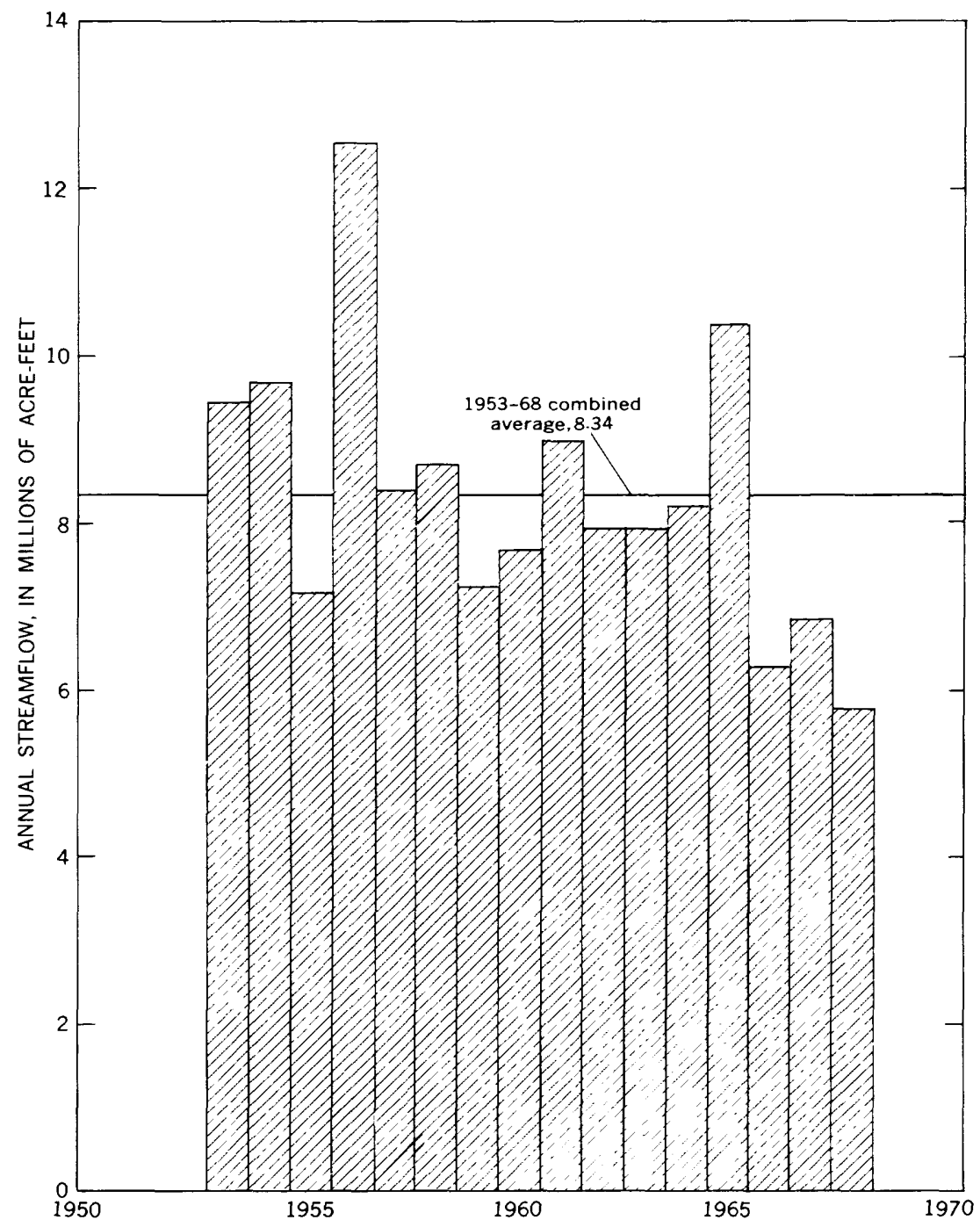

Figure 3.-Combined annual streamflow of Middle Fork Willamette River at Jasper, Coast Fork Willamette River near Goshen, and McKenzie River near Coburg, 1953-68 water years.

Average monthly gains and losses in streamflow of the Willamette River through the project area are shown in figur? 5. The largest gain, during November through June, is attributed to ground-water discharge and to direct surface runoff. TJe losses during July through October are probably due to infiltration from 


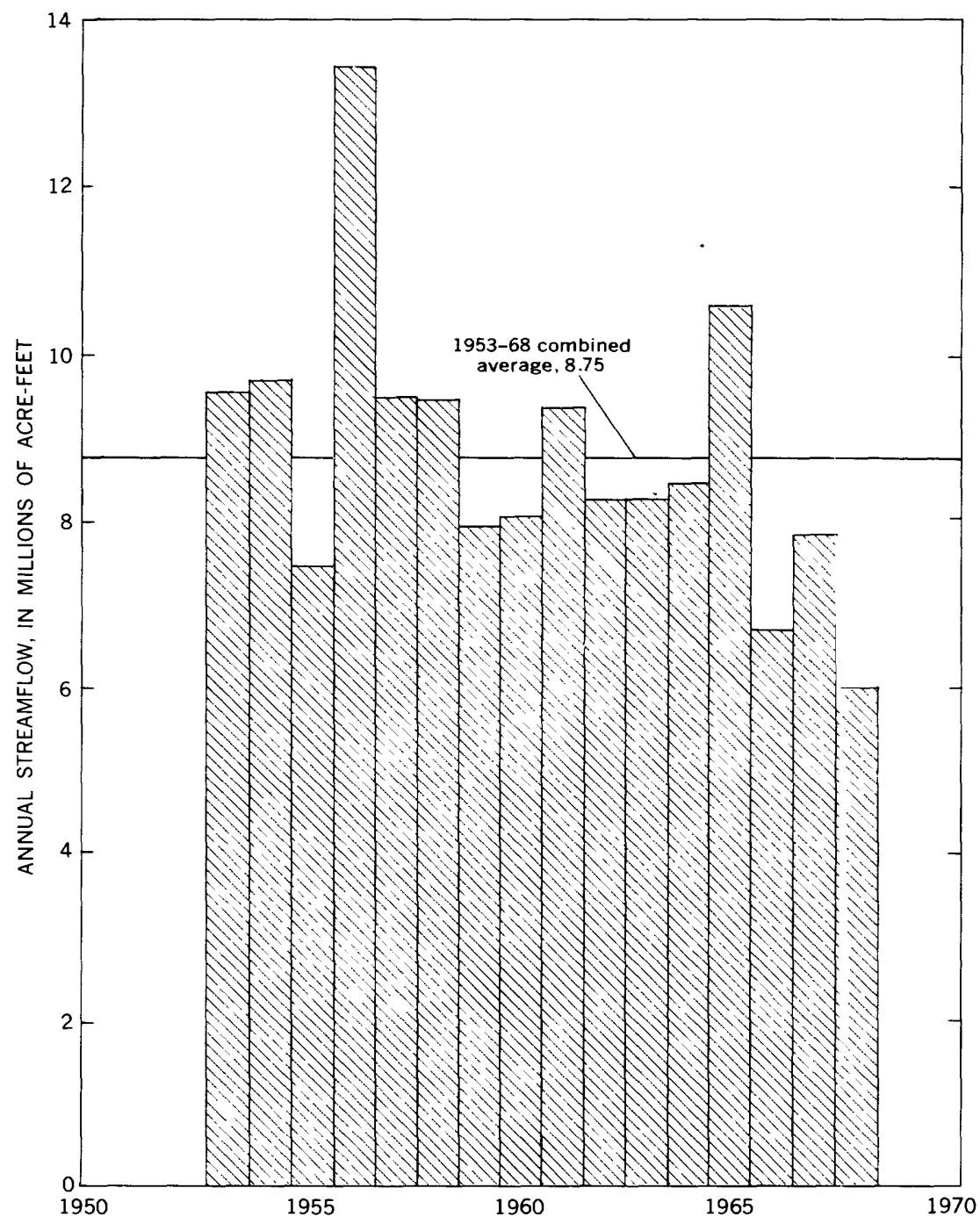

Figure 4.-Annual streamflow of Willamette River at Harrisburg, 1953-68 water years.

the river to the ground-water reservoir, diversions for irrigation, and evapotranspiration losses.

The indicated gains and losses are not accurate measurements because some of the surface inflow to the area is not ge.ged. Ungaged inflow is taken from the McKenzie River above the gaging station near Coburg (one of the stations used to determine streamflow entering the area) and is diverted for irrigation, various in- 


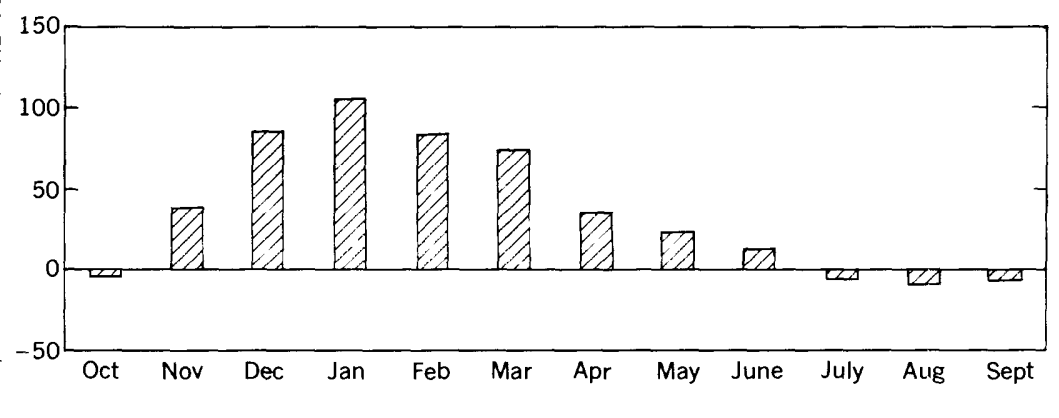

Figure 5.-Approximate average monthly gain or loss of streamflor in the Eugene-Springfield area, 1953-68.

dustrial uses, and municipal supplies for the city of Eugene. An undetermined volume of this water is returned directly to the river as waste, or indirectly to the river by ground-water s?epage. The total volume of streamflow entering the study area, as shown in figure 3, does not include the water returned to the McKenzie River above the gaging station at Coburg. Therefore, it is impossible to apply absolute values to the volumes of water as shown in figures 3 and 5. These figures, however, show that there is a small average annual gain in streamflow through the area.

\section{OTHER STREAMS}

The Mohawk River, a tributary to the McKenzie River, is the only main tributary stream that contributes stream inflow to the main Willamette Valley plain. For 22 years of record (1936-52, 1964-68), the average annual discharge of Mohawk River near Springfield is about 388,000 acre-feet.

The Long Tom River flows through the western part of the project area and enters the Willamette River about 12 river miles downstream from the north boundary of the area. Streamflow of the upper Long Tom River and its tributaries (Coyote and Amazon Creeks) is the source of water for Fern Ridge Reservoir. Most of this streamflow, except that of Amazon Creek, originates from precipitation upstream from the project area. Almost the entire basin of Amazon Creek is within the study area. This creek has a mean annual flow of 21,140 acre-feet, as measured at Amazon Creek near Eugene for the period 1955-68; of this flow, about 13,330 acre-feet is diverted into Fern Ridge Reservoir. In the project area, streamflow of the Long Tom River is measured at 
only one station, 0.2 mile downstream from Fern Ridge Dam near Alvadore. The average measured annual discharge of Long Tom River near Alvadore for 29 years of record (1940-68) is 388,800 acre-feet. Any increase in streamflow downstream from the Alvadore station is probably due to runoff from the hills west of the river. Because of tight soils and the relatively low permeabilities of the aquifers along the course of the Long Tom Fiver, little seepage of ground water can be expected to support streamflow.

No flow measurements have been made of numerous small streams that originate in the project area. Because some of these streams drain into the Willamette River, their flow is included in the total measured flow of Willamette River at Harrisburg. Some of the small streams that originate in the study area flow into the Willamette outside the area, but their combined flows are only a small increment of the total streamflow of the Willamette River downstream from the Harrisburg gaging station.

\section{UTILIZATION OF SURFACE WATER}

Surface water in the Eugene-Springfield area is usec' primarily for municipal supplies and for irrigation of adjacent farmlands.

Eugene's water supply is entirely from the McKenzie River. During 1968 the Eugene system pumped about 7 billion gallons of water, or about 21,600 acre-feet. This volume includes about 7 mgd (millions of gallons per day) of water for industrial uses, including use by plywood and fruit-processing plants, dairies, creameries, soft-drink bottling plants, and custom canreries. Additional water, diverted from the McKenzie River, is used by other industries. A pulpmill uses about $15 \mathrm{mgd}$, only $4 \mathrm{mgd}$ of which is consumed. A large volume of water, mostly for noncomsumptive uses, is also diverted from the McKenzie River for sand and gravel operations. No water is pumped from the Willamette River in the study area for industrial or municipal supplies.

It is estimated that approximately 4,000 acres of land in the study area is irrigated with water from the Willamette River and its tributaries. An estimated 15 inches (about 5,000 acre-ft) per year of surface water is applied to this land, which is mainly used for vegetables and orchards.

\section{GROUND WATER}

On the basis of geologic, hydrologic, and physiographic conditions, the study area is divided into two major units-the central lowland and the upland and valley-fringe areas. 
The central lowland is composed of younger and older alluvial deposits. These deposits contain the most productive aquifers in the study area and are considered to be the only ones feasible for large-scale development of ground-water supplies; conseq iently, elements of the hydrology are discussed in terms of their relationship to the central lowlands.

The various consolidated-rock units that make up the bulk of the upland and valley-fringe areas are not uniformly distributed throughout the area, and the hydrologic setting varies widely from one part of the area to another. For these reasons, the upland and valley-fringe areas are subdivided into three subareas-the westside, east-side, and south-end subareas. Ground-water contitions are described separately for each subarea. The locations of the major units and subdivisions are shown in figure 6.

UPLAND AND VALLEY-FRINGE AREAS

WEST SIDE

The west side of the valley-fringe area consists of the foothills of the Coast Range where they meet the level land of the upper

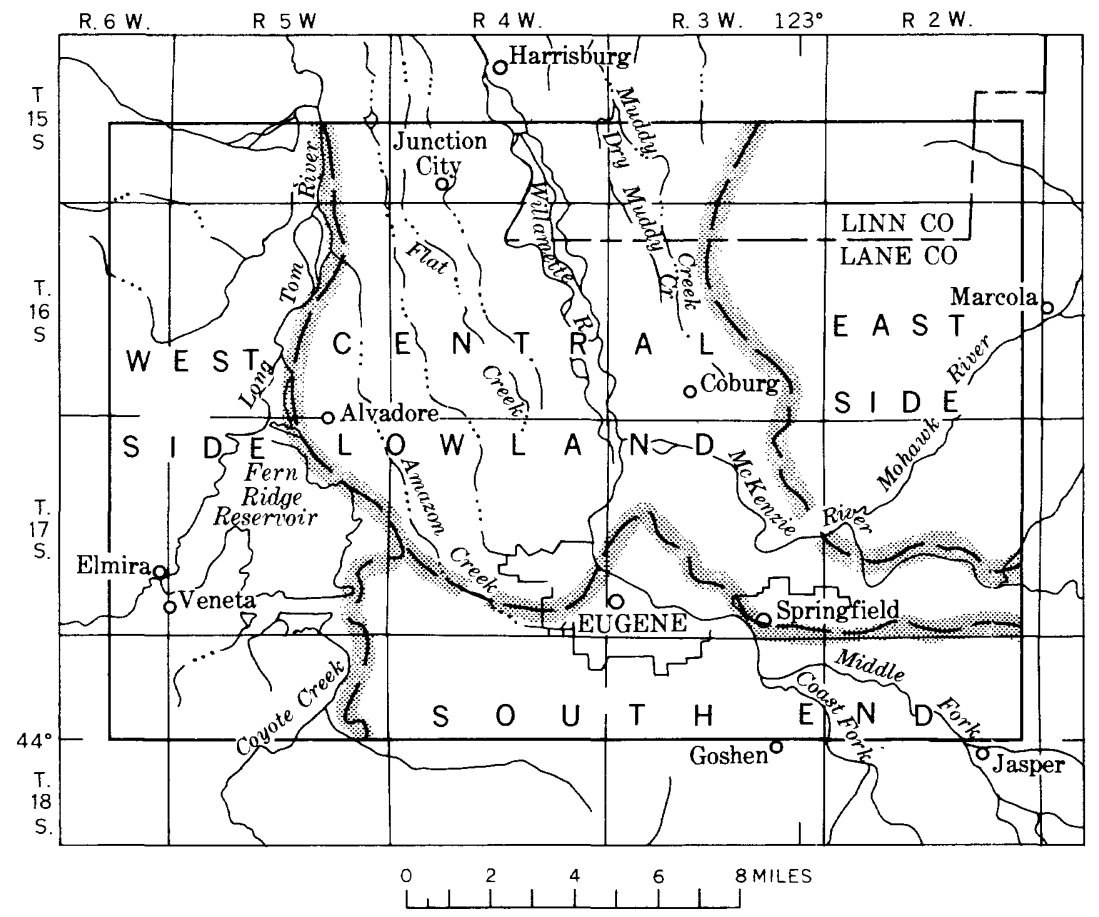

FigURE 6.-Ground-water subareas. 
Willamette Valley. It also includes Fern Ridge Reservoir and the valley margin where the older alluvium is of low permeability and generally yields water slowly to wells.

Wells in the foothills of the Coast Range penetrate a variety of rock units that generally yield small to moderate quantities of water to wells. These rock units include marine sandstone and shale of the Tyee and Spencer Formations and alluvial deposits. The water-bearing zones of the marine formations are discontinuous lenticular beds of sandstone and sandy shale that yield water slowly to wells. Few wells drilled in these formations yield as much as $10 \mathrm{gpm}$ (gallons per minute), and many yield quantities barely adequate for household use.

Because many of the wells drilled in high sandstone ridges penetrate isolated ground-water bodies perched above the rgional water table, wells in these ridges have a considerable range in depth and yield. Many of the wells in high ridges have water levels less than 50 feet below land surface, whereas some other wells nearby and at lower altitudes have much deeper water levels. Most perched-water bodies yield sufficient water for domestic requirements except during summer. Some of the water in the perched ground-water bodies occurs under confined conditions (table 8, well $16 \mathrm{~S} / 5 \mathrm{~W}-18 \mathrm{bda})$.

As residential growth in this subarea increases, many of the small discontinuous perched-water bodies may supply water for two or more families. Local residents report mutual interference between pumping wells, even where the wells are as much as a quarter of a mile apart. Many small seeps and springs are outlets for perched water, and some of them flow throughout the year. Some of these perennial springs could be developed to supply adequate water for domestic use, and others could be developed for auxiliary supplies for irrigation of lawns and gardens. Therefore, in parts of the subarea where adequate supplies of water are difficult to obtain from wells, existing springs should be investigated for quantity and quality of water and given consideration as sources of water supply.

Another major problem in the development of grourd water in the subarea is the mineral content of the water, particularly in the deeper producing zones of the bedrock. Locally, some of the water from the marine sandstone and shale is too saline for most uses. (See section on "Chemical Quality of the Ground Water.")

- Alluvium underlying the west-side subarea in T. 17 ร., R. 5 W., although not so permeable as that of the central lowland, yields moderate supplies of water to wells locally. Veneta, the largest city in the subarea, used about 22 million gallons of water during 
1968. The city obtains its water supply from two wells trat tap the alluvial aquifer. One of these wells $(17 \mathrm{~S} / 5 \mathrm{~W}-31 \mathrm{bca} 1)$ is reported to pump $190 \mathrm{gpm}$ with 58 feet of drawdown. (See table 7 for driller's $\log$ of alluvium and soil penetrated by this well.)

At some future time, when suburban development of the subarea increases the demand for water, it may become necessary to develop or transport additional water. In that event, it may be feasible to develop an infiltrated ground-water supply by constructing wells in the permeable alluvial deposits adjacent to Fern Ridge Reservoir. The alluvial materials along the Long Tom River north of T. 17 S., R. 5 W., are thin and relatively impermeable and will contribute only small quantities of water to wells. Along Ferguson, Bear, Coyote, and other creeks in the area, including intermittent streams, alluvial deposits are generally thin and store little water. However, where the deposits are thicker, as near Fern Ridge Reservoir, they may contain enough saturated materials to yield more water to relatively shallow wells than is usually yielfed by underlying marine deposits.

\section{EAST SIDE}

The east-side subarea includes the Mohawk River valley, the upland and foothill areas to the north and west, and the foothills to the east of the valley. The two main aquifers in the subarea are the older alluvium, which makes up the Mohawk valley fll, and the Little Butte Volcanic Series, which comprises the upland and foothill parts of the subarea. Depths of wells and volumes of water obtainable vary from place to place in the uplands and forthills. (See table 8, records of wells $17 \mathrm{~S} / 2 \mathrm{~W}-8 \mathrm{cdb} 2,-9 \mathrm{bca}$, and -17bcb1.) However, at most places, enough water for domestic use can be obtained from wells less than 300 feet deep.

In the foothills and uplands, much of the ground water occurs under perched conditions. Under some circumstances, the perched water is semiconfined or confined, which may explain the artesian character of well $16 \mathrm{~S} / 2 \mathrm{~W}-14 a d d$ (table 8 ). Many small springs, some of which provide water for domestic use, are outlets for perched water in the subarea.

Sandstone of the Eugene Formation is exposed at the base of the foothills northwest of the Mohawk River valley and northeast of Coburg. In most places in this part of the subarea, supplies of water adequate for domestic use can generally be obtainel from this formation; in other places, the formation is poorly permeable and yields inadequate quantities of water for domestic use. (See table 8 , records of wells $15 \mathrm{~S} / 3 \mathrm{~W}-26$ baa and $16 \mathrm{~S} / 3 \mathrm{~W}-2 \mathrm{~b}$ ?c and -9aad.) 
Small to moderate quantities of water are yielded to wells by aquifers in the older alluvial deposits of the Mohawk River valley. Here, the alluvium ranges from a featheredge along the outer margin of the alluvium to at least 125 feet thick underlying the valley floor. (See table 8 , well $16 \mathrm{~S} / 2 \mathrm{~W}-27 \mathrm{dcd} 1$.) Depth of wells completed in the alluvial deposits in this part of the subarea averages about 75 feet.

Annual water-level fluctuations in the alluvium range from about 3 to 10 feet. Hydrographs of wells $16 \mathrm{~S} / 2 \mathrm{~W}-34 \mathrm{cdc}$ and -26ccc (fig. 7) show that water levels recover fully following seasonal decline each year, an indication that additional water could be pumped from the alluvial aquifer each year without causing an overdraft.

\section{SOUTH END}

This subarea includes (1) the city of Eugene and immediate foothills to the south, west, and east, (2) short reaches of the Coast and Middle Fork branches of the Willamette River, and (3) a small part of the Willamette alluvial valley adjacent to Skinner, Gillespie, and other buttes at the north edge of Eugene. In the third area, alluvial deposits are thin and have little potential for additional development.

The aquifers in the subarea are the marine-deposited sediments of the Eugene Formation, the pyroclastic rocks of the Fisher Formation, older alluvial deposits at the valley fringes, younger

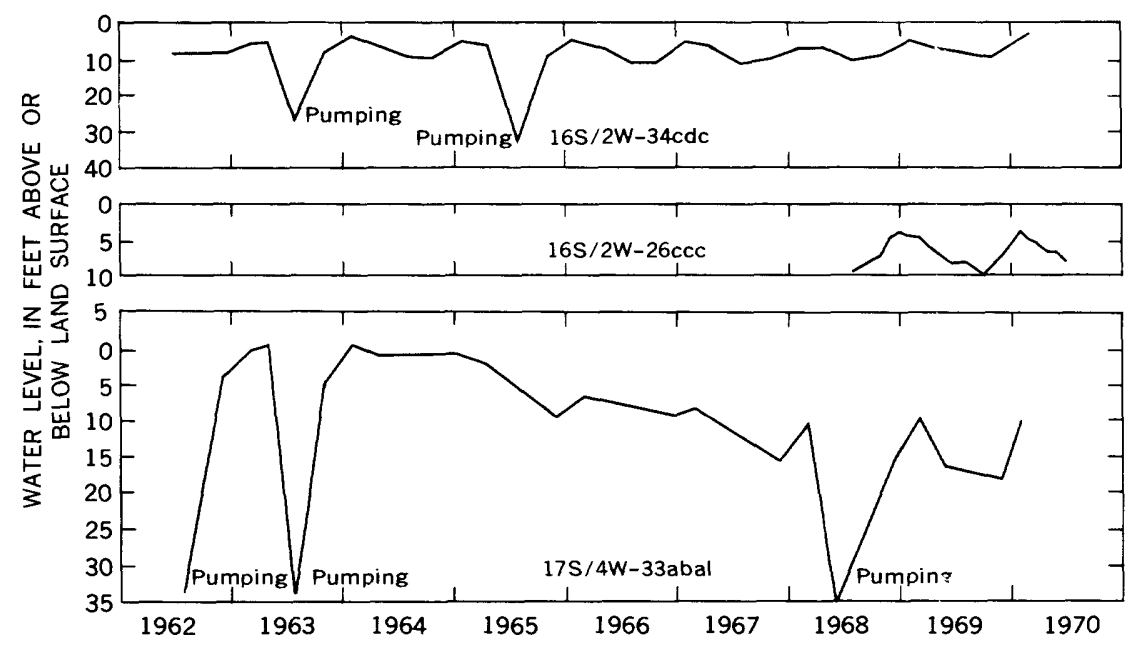

FIGURE 7.-Hydrographs of wells $16 \mathrm{~S} / 2 \mathrm{~W}-34 \mathrm{cdc},-26 \mathrm{ccc}$, and $17 \mathrm{~S} / 4 \mathrm{~W}-33 \mathrm{aba} 1$. 
alluvium adjacent to the Middle and Coast Forks of the Willamette, and the Little Butte Volcanic Series.

The most productive aquifers are the older and younger alluvial deposits. Because the older alluvium is thin, the capacity of wells drilled into it diminishes as water levels decline, and during summer large withdrawals of water cannot be sustained. Well $17 \mathrm{~S} / 4 \mathrm{~W}-33 \mathrm{aba1}$ (table 7) is representative of wells that extend through a relatively thin section of the older alluvium and are completed in the Eugene Formation. This well penetrates 51 feet of the older alluvium and 99 feet of the Eugene Formation. Figure 7 includes a hydrograph of well $17 \mathrm{~S} / 4 \mathrm{~W}-33 \mathrm{abal}$ which shows yearly declines in water level. These declines indicate that the saturated section of older alluvium cannot support heavy withd"awals of water and that some overdraft of the Eugene Formation may exist at this location.

Well 18S/3W-12ddd (table 8) is fairly representative of wells drilled in the younger alluvium. This well is 65 feet deep and is reported to yield $40 \mathrm{gpm}$ with 30 feet of drawdown after 1 rour of bailing. Adequate domestic water supplies can be obtained from the younger alluvium; however, this formation in the south-end subarea is not so permeable as the younger alluvium in the central lowland. Wells drilled in the younger alluvium may not sustain yields necessary for large-scale irrigation unless they are drilled in permeable deposits adjacent to the river in order to develop an infiltration supply.

The Eugene Formation yields a limited supply of water to most wells, as does the Fisher Formation. The low water-yielding characteristics of the Eugene and Fisher Formations are esrocially critical near Oak and Murray Hills southwest of Eugene. In this part of the subarea, many wells produce limited supplies of water even for domestic use during summer, and most of the springs cease to flow shortly after cessation of spring rains. Bece.use of increasing urbanization, additional water supplies may have to be imported as ground-water supplies become inadequate. In places the Fisher Formation yields water of high arsenic content, as discussed in the section "Chemical Quality of the Ground Water."

The Little Butte Volcanic Series occurs in the southeastern corner of the subarea and in the Wallace Creek district. Here water is obtained from basalt, volcanic-breccia flows, tuff, and agglomerate. These volcanic rocks generally yield small quentities of ground water, usually adequate for domestic and stock uses. Perched water occurs at various elevations, and many small springs are outlets for perched water. A few of these sprirgs are reported to flow throughout the year. 


\section{CENTRAL LOWLAND}

OCCURRENCE AND MOVEMENT OF GROUND WATER

Throughout the greater part of the central lowland, ground water occurs under unconfined or water-table conditions. The shape and slope of the water table are shown in the map (pl. 3) by contours connecting points on the water table that have the same altitudes. Water-level contours show the configuration of the water surface, just as topographic contours show the sl ape of the land surface. In general, the direction of movement of the ground water is at right angles to the contours in the direction of downward slope.

During most of the year, the general direction of ground-water movement is from the outer margins of the central lowlends (pl. 3) toward the Willamette River and in a general downstroam direction. Some of the water discharges by evapotranspiration on the valley plain; some discharges into the river; and some moves northwestward parallel to the river, ultimately dischar ring to the river outside the boundaries of the study area.

When the rainy season begins, the stage of the Willarette River and the ground-water levels both rise. The rise in the water table is caused partly by the direct infiltration of precipitation locally and by seepage of water from streams into the highly permeable younger alluvium adjacent to the stream channels. In the older alluvium the water-table rise is not uniform because of areal differences in permeability. Ground-water ridges form where permeability of the older alluvium is low, near its contact with the younger alluvium (pl. 3). Water-table troughs form in more permeable parts of the older alluvium, for instance, alorg Amazon Creek. The ridges block the movement of ground water from the margins of the valley plain toward the river, and the vrater tends to move downvalley along the water-table troughs. The configuration of ridges and troughs changes during the rainy season as water is added to the ground-water body or is discharged from it. During late summer the ground-water ridges in the older alluvium show a general flattening (pl. 3).

The rate of ground-water movement depends on (1) the permeability or ease with which water can move through the saturated deposits, (2) the hydraulic gradient (slope of the water table), and (3) the cross-sectional area through which the ground water is moving. The flow velocities in coarse material such as sand and gravel are generally greater than those in fine material such as silt and clay. 
Interrelationships of the Willamette and McKenzie Rivers and ground water in the alluvial deposits are illustrated by figures 8 and 9. Because of the geographic location of the wells with respect to the stream gages, figures 8 and 9 cannot be used to depict the numerical and directional relation of ground-water lerels to stream stage. However, plate 3 and figures 8 and 9 show that ground water and surface water are intimately interrelated.

In the younger alluvial deposits along the Willamette and McKenzie Rivers, fluctuations of ground-water levels seem to follow closely stream-stage fluctuations as well as seasonal trends in precipitation (fig. 8). Although the yearly saturation of the younger alluvial deposits is due to a considerable extent to direct infiltration of precipitation that falls on the area, some of the increased streamflow at the onset of the rainy season percolates into these deposits. Evidence of river contributions of water to the younger alluvial deposits is shown in figures 5 and 8 . Figure 8 shows that during the low-precipitation months of July, August, and September, rises in river stage caused by releases of water from upstream reservoirs create similar rises in ground-water levels adjacent to the river. (See section on "Streams and Reservoirs.") Figure 5 shows a loss in streamflow during July tr rough October, part of which may be contributed by the streams to the ground-water body in the younger alluvium.

A considerable volume of water could be developed from strategically placed wells by induced stream infiltration from the Willamette and McKenzie Rivers. Such infiltration would be at the expense of streamflow and would be successful only where highly permeable materials in the younger alluvium are in direct contact with the stream channel.

Along certain reaches of the Willamette and McKenzie Pivers, the younger alluvium contributes water to the streams throughout the year, as indicated by plate 3. Near Eugene the alluvium is partially dewatered by smaller streams which contribute water to the rivers in the southernmost part of the study area. At lowriver stage the younger alluvium in the southern part of tre central lowland contributes water to streamflow and this causes a lowering of the water level in the alluvium.

The movement of water from one environment to another illustrates that water in the younger alluvial aquifer and water in the rivers are not separate entities but are connected and interdependent parts of the water-supply system. Therefore, whatever 


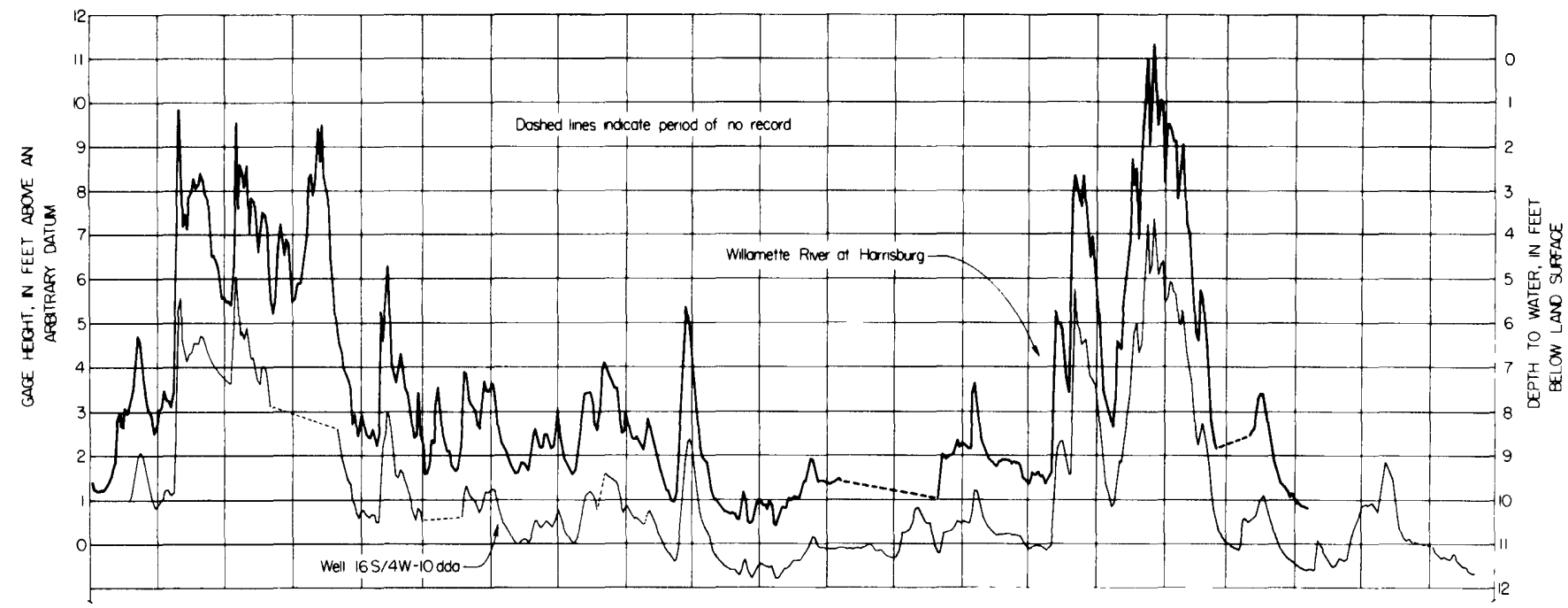

Ficuns S.-Stage of the Willamatte and McKenzie Divers, water levels in nearby wells, and daily precipitation. 


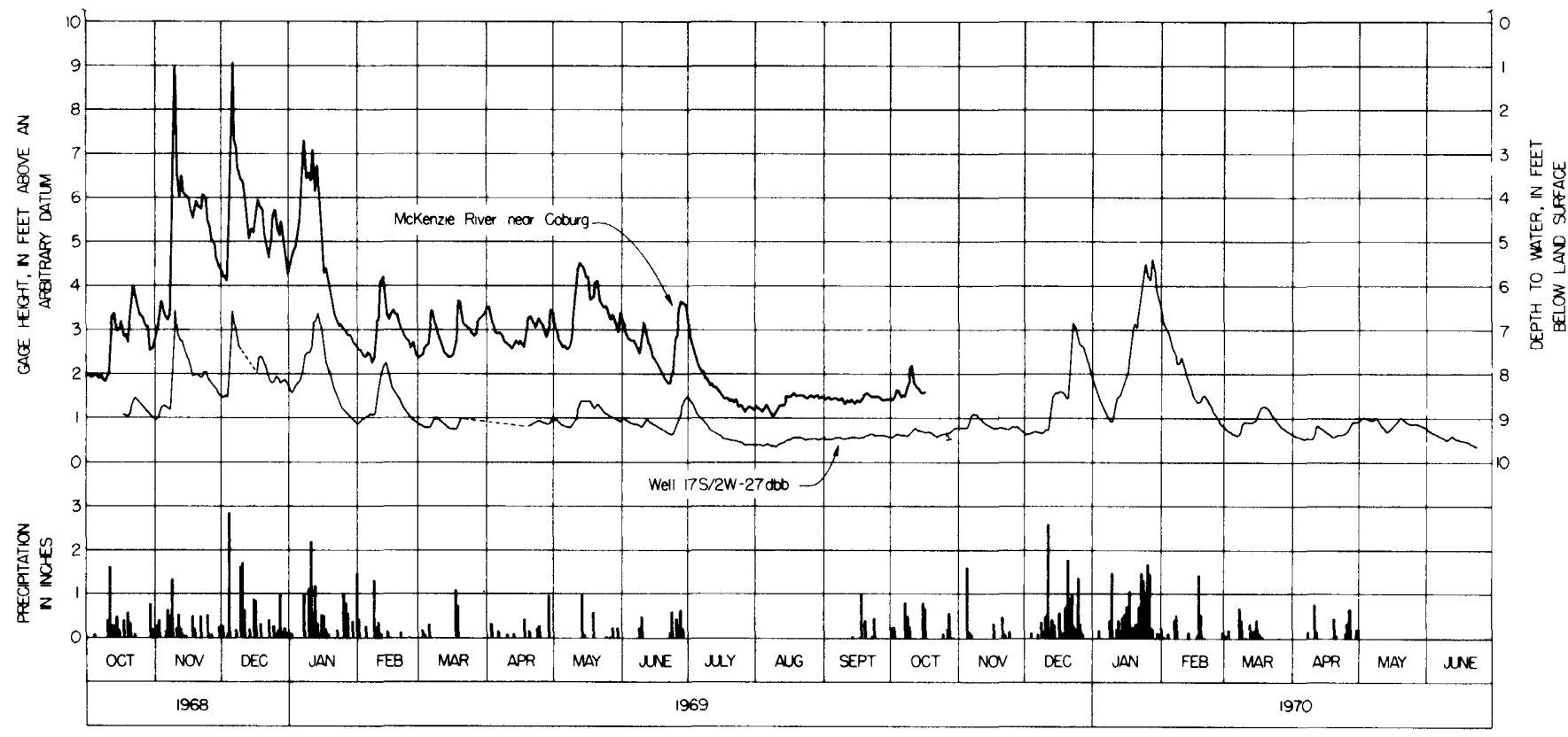

是

Figure 8.-Gontinued. 


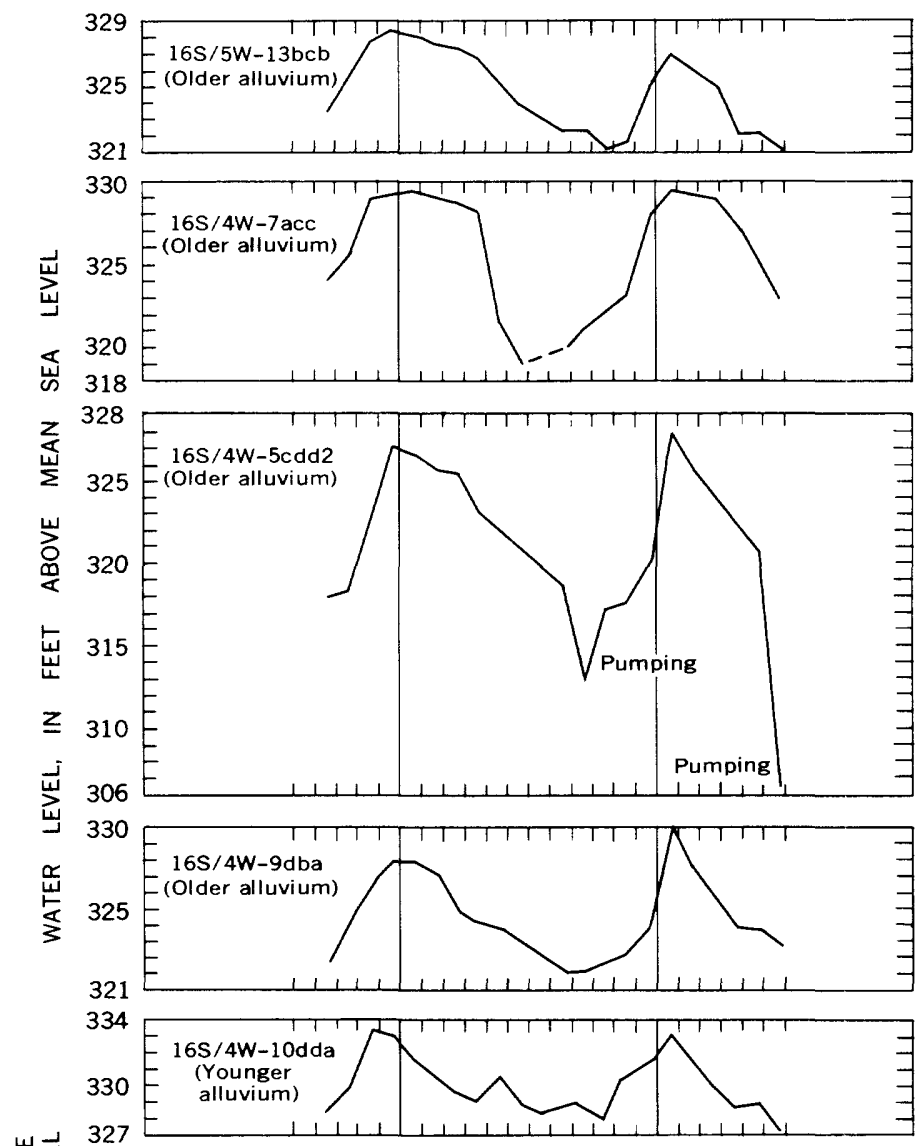

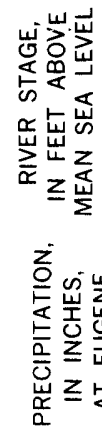

327
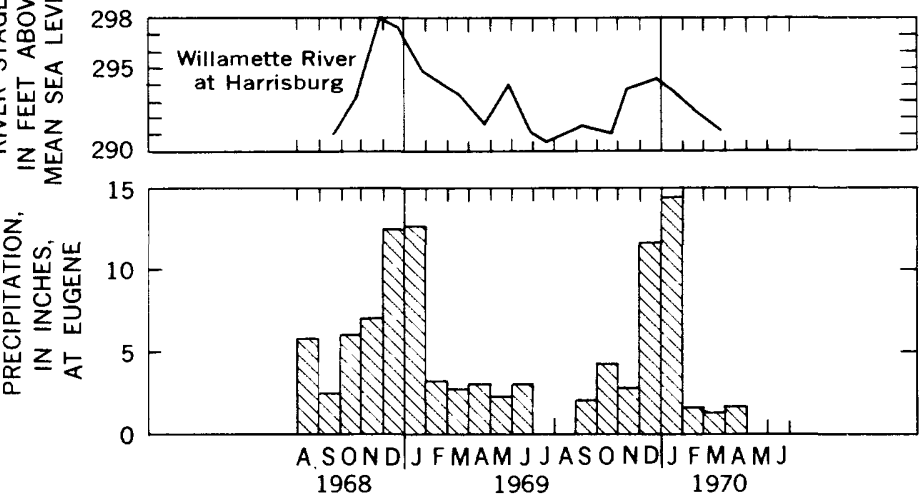

Figure 9.-Hydrographs showing the relationship of the Willamette River stage to water levels of wells in the younger and older alluvium. 
affects the quantity of water in one part affects the quantity of water in another part.

Figure 9 shows the general relationship between precipitation, the Willamette River stage, and water levels of wells in the younger and older alluvium. This figure consists of a series of hydrographs showing monthly measurements of water levels and the river stage on the same day the water levels were measured. Reading upward, the first hydrograph in figure 13 represents the stage of Willamette River at Harrisburg (gaging station 14-1660). Succeeding hydrographs are for wells at progressively greater distances northwestward from the river, starting about 5 miles south of the gaging station. Water levels in the younger alluvium, as shown by the hydrograph of well $16 \mathrm{~S} / 4 \mathrm{~W}-10 \mathrm{dda}$ (fig. 8 ), have the same fluctuation pattern, particularly during April and INay of 1969 , as does the stage of the river. Farther to the north and west, starting with well 16S/4W-9dba (fig. 9) and continuing southwest to well $16 \mathrm{~S} / 5 \mathrm{~W}-13 \mathrm{bcb}$, the hydrographs of wells in the older alluvium agree generally with precipitation trends but shcre less relationship to river stage than do wells in the younger alluvium.

Because of the relationship of the younger alluvial depcsits to the Willamette and McKenzie Rivers, changes in stream-channel regimen will be reflected in the water levels of the adjacent younger alluvial deposits. If river channels were widened and deepened, there would be an increase in the gradient of the adjacent water table toward the stream; the result would be a lowering of the water table in the alluvial deposits. Conversely, ary constriction of stream channels would tend to raise the river stage and consequently raise the ground-water levels in the ac'jacent alluvium.

TRANSMISSIVITY AND STORAGE COEFFICIENT

The transmissivity and storage coefficient express certain waterbearing properties of the aquifers in the central lowland. Transmissivity is a measure of the ability of an aquifer to transmit water and is dependent on the permeability and thickness of the aquifer. The storage coefficient is the volume of water an aquifer releases from storage from a unit surface area per unit chenge in head. Transmissivity and storage coefficient can be used to compute drawdowns and storage changes caused by pumping or to determine subsurface flow.

During this study, three pumping tests were made by tre U.S. Geological Survey to obtain information on the water-transmitting capacity of the alluvial aquifers. Results of the tests are 
tabulated in table 3. Because none of these tests was made under ideal conditions, the storage coefficients and transmissivities determined from the tests are probably only rough approximations of the true values. Results of five pumping tests made by others are included in table 3. Methods used for analyzing the pumping tests are summarized by Ferris, Knowles, Brown, and Stallman (1962).

Transmissivity can also be estimated from specific capacities of wells (Theis and others, 1963, p. 331-340). The specific capacity of a well is determined by dividing its yield in gallons per minute by the drawdown at the end of the pumping period. Specific capacities were determined for five of the wells on which pumping tests were made. Transmissivities determined from pumping tests and from specific-capacity data are included in table 3.

Storage coefficients were calculated for three wells. The small storage coefficients for the aquifer at wells $15 \mathrm{~S} / 4 \mathrm{~W}-28 \mathrm{bad} 2$, $16 \mathrm{~S} / 3 \mathrm{~W}-32 \mathrm{dbd} 1$, and $17 \mathrm{~S} / 2 \mathrm{~W}-26 \mathrm{cca} 1$ indicate a partially confined ground-water body. Storage coefficients for confined aquifers typically have values of less than 0.001 . Lenses of silt and clay in the alluvial aquifers indicate that in places the horizontal permeability of the central lowland is much greater than the vertical permeability and that for short periods the flow system may respond to pumping stress as a confined system. Over lcng periods, however, all deposits of the central lowland will drain slowly in response to pumping, and the storage coefficient will be nearly equal to the specific yield. Therefore, the central lowland must be considered as a water-table system. Storage coefficients may be approximated from the specific-yield values discussed in the following section.

GROUND-WATER STORAGE

Ground water in storage is water filling the openings in rocks in the zone of saturation. However, only that part of the water that will drain from the materials by gravity flow can be cc nsidered to be a manageable part of the ground-water resource. Because some water will be retained in the alluvial deposits by capillary, molecular, and other forces, not all the ground water stored in the pores of the saturated materials beneath the area is available. A knowledge of the volume of water in storage and the volumes of water that are discharged and recharged annually is required if the ground-water resources of the area are to be managed properly. 
TABLE 3.-Results of aquifer tests

\begin{tabular}{|c|c|c|c|c|c|c|c|c|c|c|c|}
\hline \multirow[b]{2}{*}{$\begin{array}{c}\text { Well } \\
\text { number }\end{array}$} & & \multirow[b]{2}{*}{$\begin{array}{c}\text { Date of } \\
\text { pumping } \\
\text { test }\end{array}$} & \multicolumn{4}{|c|}{ Data from pumping tests } & \multicolumn{2}{|c|}{$\begin{array}{c}\text { Transmissivity } \\
\left(\mathrm{ft}^{2} \text { per day }\right)\end{array}$} & \multirow[b]{2}{*}{$\begin{array}{l}\text { Storage } \\
\text { coefficient }\end{array}$} & \multirow[b]{2}{*}{$\begin{array}{l}\text { Saturated } \\
\text { thickness } \\
\text { of reser- } \\
\text { voir } \\
\text { (feet) }\end{array}$} & \multirow[b]{2}{*}{ Remarks } \\
\hline & & & $\begin{array}{c}\text { Length of } \\
\text { test } \\
\text { (hours) }\end{array}$ & $\begin{array}{c}\text { Pumping } \\
\text { rate } \\
\text { (g pm) }\end{array}$ & $\begin{array}{l}\text { Drawdown } \\
\text { (feet) }\end{array}$ & $\begin{array}{l}\text { Specific } \\
\text { capacity } \\
(\mathrm{gpm} \text { per } \\
\text { ft) }\end{array}$ & $\begin{array}{l}\text { Based on } \\
\text { specific } \\
\text { capacity }\end{array}$ & $\begin{array}{l}\text { Based on } \\
\text { analysis of } \\
\text { drawdown } \\
\text { or recov- } \\
\text { ery data } \\
\text { using non- } \\
\text { equilibrium } \\
\text { formula }\end{array}$ & & & \\
\hline \multirow[t]{2}{*}{$15 S / 4 W-28 b a d 2$} & -- & $7-16-69$ & 10 & 550 & 1.18 & 466 & 120,000 & 270,000 & 0.05 & 20 & $\begin{array}{l}\text { Well drilled in younger } \\
\text { alluvium. Pump tested } \\
\text { and analyzed by U.S. } \\
\text { Geological Survey. }\end{array}$ \\
\hline & -- & $7-27-68$ & 9 & 980 & 24.17 & 41 & 11,000 & 6,200 & ----- & 110 & $\begin{array}{l}\text { Well drilled in older } \\
\text { alluvium. Data from city } \\
\text { of Junction City; } \\
\text { analysis by U.S. } \\
\text { Geological Survey. }\end{array}$ \\
\hline $16 \mathrm{~S} / 3 \mathrm{~W}-30 \mathrm{dba}$ & -- & $7-10-69$ & 9 & $\mathbf{3 0 0}$ & 7.3 & 41 & 11,000 & 36,000 & $-\cdots-$ & 210 & $\begin{array}{l}\text { Well drilled in older } \\
\text { alluvium. Pump tested } \\
\text { and analyzed by U.S. } \\
\text { Geological Survey. }\end{array}$ \\
\hline 32dbd1 & -- & $8-27-69$ & 10 & 235 & 14.12 & 17 & 4,600 & 2,700 & .002 & 150 & $\begin{array}{l}\text { Most of the water from } \\
\text { o!der alluvium. Pump } \\
\text { tested and analyzed by } \\
\text { U.S. Geological Survey. }\end{array}$ \\
\hline $16 \mathrm{~S} / 4 \mathrm{~W}-25 \mathrm{ccd}$ & -- & $7-18-69$ & $481 / 2$ & 1,200 & $\cdots-\cdots$ & $\cdots-\cdots$ & $\cdots \cdots$ & 78,000 & $\cdots-$ & 26 & $\begin{array}{l}\text { Drilled in younger alluvium } \\
\text { near river. Data and } \\
\text { analysis courtesy Eugene } \\
\text { Water \& Electric Board. }\end{array}$ \\
\hline $36 \mathbf{b b c}$ & -- & $7-22-69$ & 48 & 1,230 & $--\cdots-n$ & ------ & $--\cdots-\infty$ & 79,000 & $\cdots-\cdots$ & 21 & Do. \\
\hline $36 \mathrm{bbd}$ & -- & $7-14-69$ & $501 / 2$ & 1,210 & ------ & ------ & ------- & 76,000 & ----- & 27 & $\begin{array}{l}\text { Do. } \\
\end{array}$ \\
\hline $17 \mathrm{~S} / 2 \mathrm{~W}-26 \mathrm{cca} 1$ & --- & $1-25-66$ & 18 & 875 & 10.19 & 86 & 23,000 & 67,000 & .06 & $\mathbf{5 5}$ & $\begin{array}{l}\text { Most of the water from } \\
\text { older alluvium. Data } \\
\text { from Springfield Utility } \\
\text { Board; analysis by U.S. } \\
\text { Geological Survey. }\end{array}$ \\
\hline
\end{tabular}


Storage Capacity

The storage capacity for ground water, as estimated for the central lowland, is the volume of water that would drain by gravity from the saturated rocks that form the reservoir if the regional water level were lowered from 10 feet below the surface to a depth of 150 feet.

The volume of water that drains from the saturated deposits, expressed as percentage of the total volume of the materials, is known as specific yield. To compute the volume of manageable stored water for the central lowland in the Eugene-Springfield area, specific-yield values were assigned to five lithologic types in representative wells. (See table 4.) These values were adapted

TABLE 4.-Specific yields of materials described in driller?' logs

\begin{tabular}{cc}
\hline $\begin{array}{c}\text { Lithologic type } \\
\text { (based on drillers' descriptions) }\end{array}$ & $\begin{array}{c}\text { Assirned specific- } \\
\text { yield value } \\
\text { (percent) }\end{array}$ \\
\hline $\begin{array}{l}\text { Gravel, sand and gravel, and related coarse, } \\
\text { gravelly deposits - }\end{array}$ & 25 \\
$\begin{array}{l}\text { Sand, medium to coarse, loose } \\
\text { Sand, fine, tight, and in lenses; sand containing clay }\end{array}$ & 25 \\
$\begin{array}{l}\text { lenses } \\
\text { Clay and gravel, gravel containing clay binder, con- }\end{array}$ & 15 \\
$\quad \begin{array}{l}\text { glomerate, cemented gravel, and clay containing } \\
\text { gravel lenses - silt, and related fine-grained deposits }\end{array}$ & 10 \\
\hline
\end{tabular}

with slight modification from figures used in estimating storage capacity for ground water for similar deposits, as compiled by Johnson (1967). Average specific yield, based on total thickness of respective lithologic units, was computed for each township for depth zones of 10-100 feet and 100-150 feet. The volume of saturated rocks in each depth zone was then multiplied by the computed average specific yield to obtain the volume of recoverable ground water. Because the alluvial deposits generally consist $c f$ finer materials below the 100-foot-depth zone, separate computations were made for the 100- to 150-foot depth interval and later combined to obtain the total volume of recoverable ground water.

The average specific yield of the materials in the 10- to 100-footdepth interval ranged from 13.1 percent in T. $15 \mathrm{~S}$., Rs. 4 and $5 \mathrm{~W}$., to about 19.2 percent in T. 17 S., Rs. 2 and $3 \mathrm{~W}$. The overall average specific yield of materials in the upper depth interval was 15.2 percent, and the overall average specific yield of the materials in the 100 - to 150 -foot-depth interval was 12.9 percent. The average specific yield of both zones was 14.2 percent. The ground-water storage was computed to be about $1,400,000$ acre-feet for the 10to 100 -foot-depth zone and about 700,000 acre-feet for the 100- to 
150-foot-depth zone. The total storage capacity for ground water for the 150-square-mile central lowland is the sum of these two, or about 2.1 million acre-feet of manageable stored water.

There is additional ground water of good quality available for recovery below the 150 -foot-depth zone; however, there are insufficient well logs and quality-of-water data for aquifers below the 150-foot-depth level on which to base quantitative estimates.

\section{Changes in Storage}

Fluctuation of water levels in wells indicates changes in the volume of ground water in storage. Because these fluctuations occur mostly in response to changes in the rates of recherge or discharge of ground water, the volume of ground water in storage varies seasonally and annually. Increases in the volume of ground water in storage result in rises in ground-water levels; decreases in volume of ground water in storage result in a lowering of ground-water levels. Records of water levels in wells show that ground-water levels start to rise as precipitation and infil tration increase during October and November, continue at a high level during the rainy winter months, and decline as rainfall diminishes and evaporation and transpiration increase during spring and summer. (See fig. 10.) Ground-water levels in wells are at their lowest in September and October of each year.

\section{REPLENISHMENT OF STORAGE}

Ground-water storage in the central lowland is replenished principally by direct infiltration of precipitation that falls on the valley floor. Because much of the area is flat, only a small volume of precipitation runs off directly. The soils absorb moisture readily, and therefore precipitation can quickly restore soil-moisture deficiencies and percolate to the water table. Most of the precipitation (about 40 inches per year average) occurs in winter when little moisture is lost by evapotranspiration. The volume of precipitation that falls on the 97,300 acres of the central lowland is about 320,000 acre-feet annually, but because of direct runoff and evapotranspiration from the soil zone, recharge is less.

Figure 11 shows the relationship between precipitation and changes in storage as represented by a composite hydrograph of average water levels in $\mathbf{1 5}$ observation wells in the central lcwland. When water levels are highest, the reservoir is considered to be replenished, and when the water levels decline, ground water is being removed from storage. Records of the 15 wells stow an average seasonal fluctuation of about 7 feet during water years 


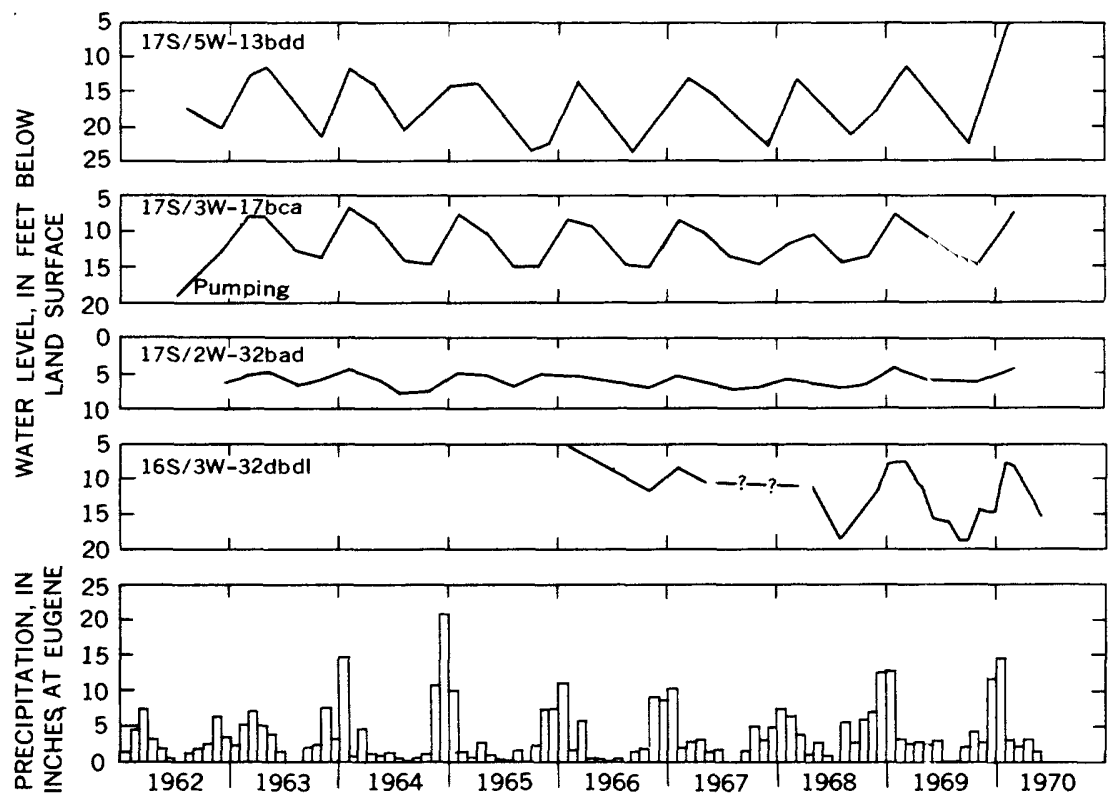

Figure 10.-Hydrographs showing changes in water levels of observation wells in relation to precipitation.

1969-70. This fluctuation represents a change in ground-water storage and in thickness of the zone of saturation.

As shown in figure 11, precipitation from July through September 1969 cansed little rise of the water level even though 2 inches of rain fell during September. However, water levels started to rise during October 1969 and rose from a seasonal low of about 12 feet in September to a seasonal high of about 5 feet in January 1970.

Although precipitation during 1969-70 was substantially above normal, the hydrographs shown in figure 10 indicate that seasonal water-level fluctuations during this period were about the same as the long-term average. Periodic water-level measurenents made in well 16S/3W-32acd1 during 1928-65 (Frank and Johnson, 1970) show that seasonal fluctuations of the water table have been in the same range for more than 30 years.

Water-level measurements made in wells in the central lowland indicate changes in thickness of the zone of saturation, which represent seasonal changes in ground-water storage. Volumetric change in ground-water storage may be calculated by multiplying the change of the water table by the specific yield of the aquifer material affected. Average specific yield of the alluvial materials 

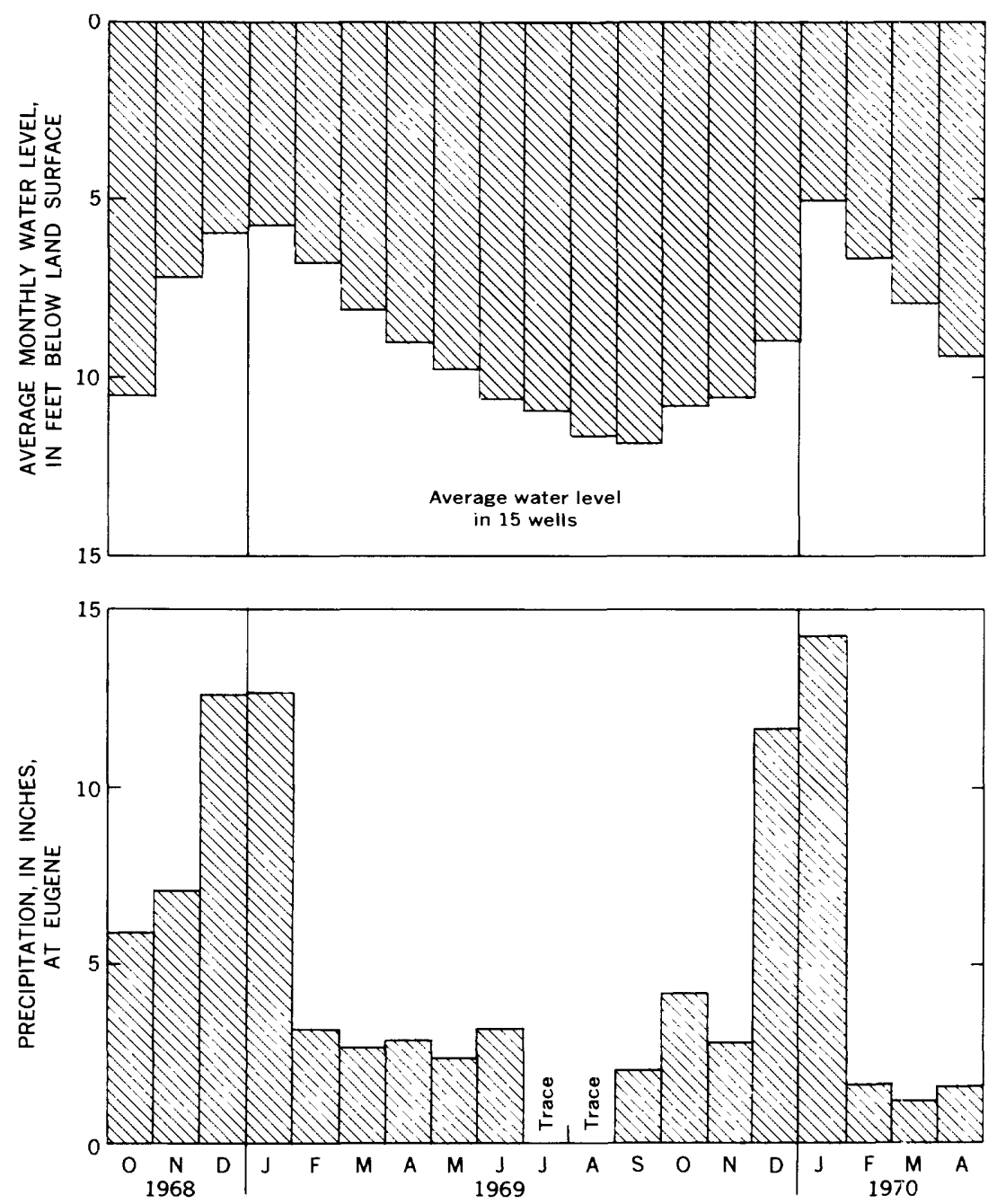

FIGURE 11.-Composite hydrograph of average water levels in 15 observation wells, showing the relationship between precipitation and change in groundwater storage.

in the 10- to 100 -foot-depth zone of the central lowland is about 15 percent, and the average annual fluctuation of the water te.ble is about 7 feet. Therefore, the seasonal change in ground-water levels in 1969-70 is estimated to be equal to about 13 incles of water, or about 100,000 acre-feet. That volume of water represents the net recharge added to aquifer storage during OctoberJanuary. The total volume infiltrated during these months was greater than 100,000 acre-feet because some ground water wes dis- 
charged by seepage to streams as the water table rose. The water table reached its seasonal peak in January and declined in late winter and early spring. Some water no doubt infiltrated to the aquifer from precipitation in the February-May period, but the rate of infiltration was slower than the rate of natural discharge. Consequently, total recharge was equal to the 13 incres referred to above, plus an undetermined volume lost by natural discharge. Therefore, 13 inches may be considered a conservative estimate of the minimum average recharge. Other sources of rech arge to the central lowland are an undetermined volume of underfow into the area from alluvium of the McKenzie River and the Coast and Middle Forks of the Willamette River, and infiltration from irrigation and fluid-waste disposal.

\section{DePletion OF STORAGE}

Ground-water storage of the central lowland is depleted seasonally by natural discharge of ground water through the seeps and springs that abound in ravines, sloughs, and other irregularities of the surface. Small streams, such as Spring and Amazon Creeks near Eugene, are fed by this type of ground-water discharge. The reservoir storage for ground water is further depletec by subsurface outflow to adjacent areas and by evapotranspiration. The volume of natural discharge no doubt is large, but data for all factors necessary for an estimate of total natural discharge were not available. Additional water is artificially discharged by pumping from wells.

\section{GROUND-WATER USE}

Ground water supplies a major part of the water required for irrigation in the study area. Most of the ground water used for irrigation is pumped by electric power. The electric-power data (in kilowatt-hours) for irrigation wells for 1968 were obtained from records of Pacific Power \& Light Co., Eugene Water \& Electric Board, Blachly-Lane County Coop. Electric Assoc., and Lane County Electric Coop. for their respective power districts in the report area.

Water pumped for irrigation was calculated by dividing total kilowatt-hours of power consumed by a factor for kilowatt-hours per acre-foot of water pumped, as determined from an assumed overall efficiency rating of 60 percent, and adjusted for total pumping lift. The cities of Springfield and Junction City and the town of Coburg obtain public water supplies from wells. When available, data on quantity of ground water pumped for municipal and 
domestic use by these communities were obtained from municipal records of water pumped from wells. Where figures for pumpage by municipalities could not be obtained, they were estimated on the basis of population. The quantity of ground water pump?d for domestic and livestock uses in rural areas was estimated. The total volume of ground water pumped from wells in the contral lowland during 1968 is estimated to be about 23,000 acre-feet. The volume of water pumped for each use during 1968 is given in the following table:

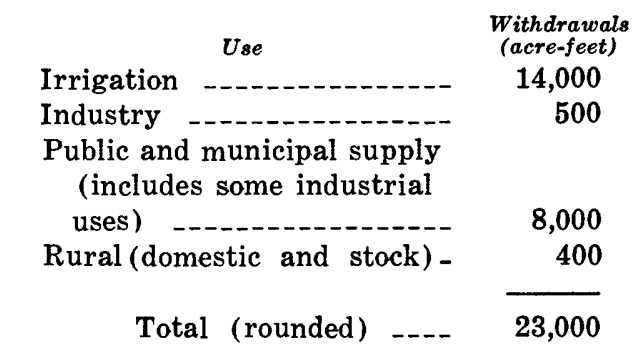

CHEMICAL QUALITY OF THE GROUND WATER

Because water is a solvent for practically all minerals, all ground water contains certain chemical elements in solutior. The ability of water to dissolve minerals is aided by the presence of dissolved carbon dioxide which combines with water to form a weak solution of carbonic acid. Some carbon dioxide is disqolved directly from the atmosphere by rainwater; a greater amount is derived from the decomposition of organic matter in the soil.

EXPLANATION OF QUALITY-OF-WATER DATA

"Dissolved solids" refers to the substances dissolved in water. In this report, concentrations of dissolved mineral constituents are reported in milligrams per liter. For example, $1 \mathrm{mg} / 1$ (milligram per liter) is equivalent to 1 pound of substance per million pounds of water, or about 8.33 pounds per million gallons of water. The U.S. Public Health Service (1962) recommends that the dissolved solids in drinking water should not exceed $500 \mathrm{mg} / 1$. Water containing more than $1,000 \mathrm{mg} / 1$ of dissolved solids is unsuitable for many uses.

Specific conductance is a measure of the ability of water to conduct electrical current and is expressed in micromhos at $25^{\circ} \mathrm{C}$. The specific conductance of water is approximately proportic nal to the amount of dissolved solids present. Numerically, the dissolved-solids content of water in milligrams per liter is usuelly $\mathbf{5 5}$ to 75 percent of the specific-conductance value. 
Hardness of water is caused principally by dissolved calcium and magnesium and is expressed in milligrams per liter of calcium carbonate. In this report, the following numerical ranges and terms are used to classify water hardness:

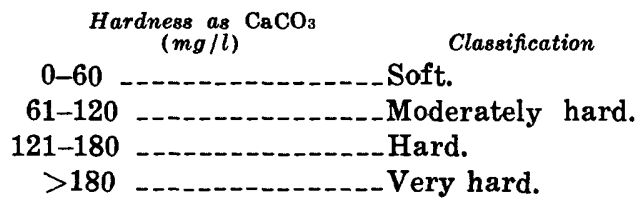

The observed hardness values for ground water in the EugeneSpringfield area ranged from 4 to $446 \mathrm{mg} / \mathrm{l}$. The water ranges from soft to very hard, and the average hardness is in the moderately hard classification.

TABLE 5.-Chemiccl analyses of

[Analyses by the U.S. Geological Survey,

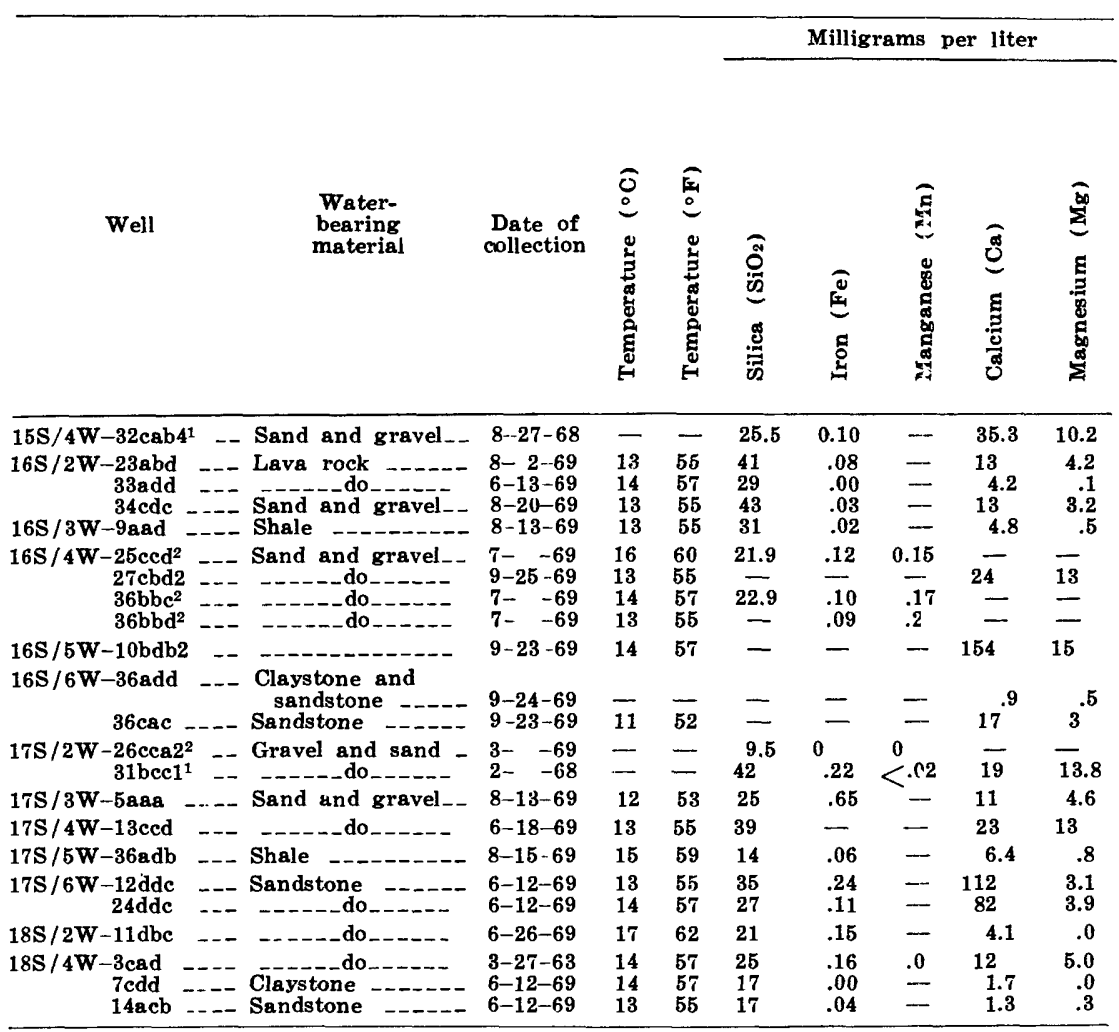

${ }^{1}$ Analysis by Charlton Laboratories. 


\section{VARIATIONS IN CHEMICAL QUALITY OF THE WATER}

Dissolved-solids content, and consequently chemical quality of the ground water, varies considerably from place to place in the Eugene-Springfield area. Table 5 contains 23 well-water analyses, 17 of which were made by the U.S. Geological Survey and the rest by commercial laboratories. Fifteen of the samples were aralyzed for most constituents usually reported in water analyses; eight were analyzed for only a few constituents.

Most ground water from the alluvial deposits beneath the valley plain contains relatively small amounts of dissolved minerals, principally silica, calcium, and bicarbonate. The dissolved-solids content of water sampled from the alluvial deposits ranged from 24 $\mathrm{mg} / \mathrm{l}$ to $382 \mathrm{mg} / \mathrm{l}$.

water in the Eugene-Springfield area

Portland, Oreg., unless otherwise noted]

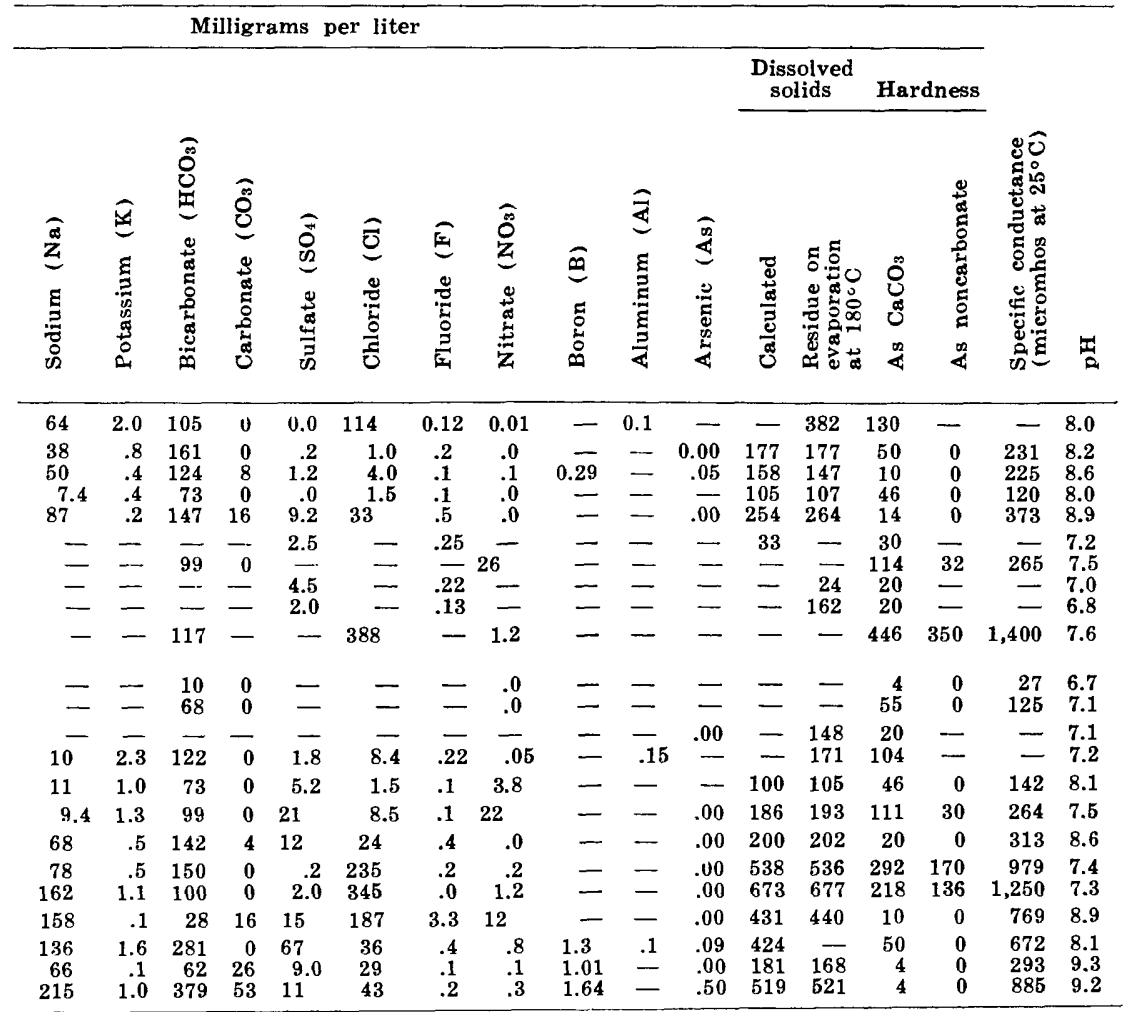

${ }^{2}$ Analysis by Cornell, Howland, Hayes \& Merryfield. 
The highest nitrate concentrations were in water from the alluvial deposits. Water from well $16 \mathrm{~S} / 4 \mathrm{~W}-27 \mathrm{cbd} 2$, reported to have a high bacteria count, had the highest nitrate concentration at 26 $\mathrm{mg} / \mathrm{l}$. Water from well $17 \mathrm{~S} / 4 \mathrm{~W}-13 \mathrm{ced}$, in an area where much of the ground water is reported to have a high bacteria count, had a nitrate concentration of $22 \mathrm{mg} / \mathrm{l}$.

The chemical analyses of water from the older marine sedimentary rocks of the Tyee and Spencer Formations irdicate that these formations contain more highly mineralized water (greater concentrations of calcium and chloride) than do most other aquifers in the area. The dissolved-solids content is larre-usually more than $500 \mathrm{mg} / \mathrm{l}$. (See table 5, analyses of water from wells $17 \mathrm{~S} / 6 \mathrm{~W}-12 \mathrm{ddc}$ and $-24 \mathrm{ddc}$.)

In the upland areas south and west of Eugene, water from some wells in the Fisher Formation contains arsenic in excess of limits recommended by the U.S. Public Health Service (1962). Water from well $18 \mathrm{~S} / 4 \mathrm{~W}-3$ cad contains $0.09 \mathrm{mg} / 1$ of arsenic and that from well $18 \mathrm{~S} / 4 \mathrm{~W}-14 \mathrm{acb}, 0.5 \mathrm{mg} / \mathrm{l}$. Another well $(16 \mathrm{~S} / 2 \mathrm{~W}-$ 33add), in the Mohawk River valley, also has a high s.rsenic content $(0.05 \mathrm{mg} / \mathrm{l})$. This well apparently taps a volcanic-rock aquifer in the Little Butte Volcanic Series. Chemical characteristics of the water containing arsenic are distinctive, sodium and bicarbonate being the principal dissolved constituents; concentrations of calcium and magnesium are usually low. The arsenic content of all water samples ranged from 0.0 to $0.50 \mathrm{mg} / 1$. The occurrence of arsenic in water in the Eugene-Springfield area is discussed in detail in a report by Goldblatt, Van Denburgh, and Marsland (1963).

\section{SUITABILITY FOR USE}

Minute amounts of some chemical ions such as arsenic and manganese can make water unsuitable for some uses. Suitability of water for drinking can be evaluated on the basis of the recommended limits established by the U.S. Public Health Service (1962) for the more common mineral constituents. All the analyses of water from the alluvial deposits indicate that the water has a low-sodium and low-salinity hazard and is suitable for irrigation. Table 6 indicates the sources of the more common chemical constituents and the significance of these constituents in the use of water in the Eugene-Springfield area.

GROUND WATER AVAILABLE FOR FUTURE DEVELOPMENT

The infiltration of precipitation results in annual replenishment of 100,000 acre-feet of ground water. (See p. 35.) Under the pres- 
TABLE 6.-Sources and significance of common chemical constituents of ground water

\begin{tabular}{|c|c|c|c|}
\hline Constitutent & $\begin{array}{l}\text { Recom- } \\
\text { mended } \\
\text { limits for } \\
\text { drinking } \\
\text { water } \\
(\mathrm{mg} / 1)\end{array}$ & Principal sources & $\begin{array}{c}\text { Significance with respect } \\
\text { to use }\end{array}$ \\
\hline Silica $\left(\mathrm{SiO}_{2}\right)$ & - & $\begin{array}{l}\text { Siliceous minerals present } \\
\text { in unconsolidated and } \\
\text { consolidated deposits. }\end{array}$ & $\begin{array}{l}\text { May form scale in pipes and } \\
\text { boilers used in zeolite-type } \\
\text { water softeners. }\end{array}$ \\
\hline Iron $(\mathrm{Fe})$ & 0.3 & $\begin{array}{l}\text { Common iron-bearing } \\
\text { minerals present in most } \\
\text { rocks in the area. }\end{array}$ & $\begin{array}{l}\text { More than about } 0.3 \mathrm{mg} / 1 \\
\text { may stain laundry and } \\
\text { utensils. Larger quantities } \\
\text { may color and impart ob- } \\
\text { jectionable taste to water. }\end{array}$ \\
\hline Manganese $(\mathrm{Mn}) \ldots$ & .05 & $\begin{array}{l}\text { Manganese-bearing } \\
\text { minerals. }\end{array}$ & $\begin{array}{l}\text { Same objectionable features as } \\
\text { iron. Causes dark-brown or } \\
\text { black stain. }\end{array}$ \\
\hline Calcium (Ca) $\ldots--$ & - & $\begin{array}{l}\text { Most of the consolidated } \\
\text { and unconsolidated } \\
\text { deposits. }\end{array}$ & $\begin{array}{l}\text { Principal cause of hardness. } \\
\text { Commoniy a major con- } \\
\text { stituent in scale de oosits. }\end{array}$ \\
\hline Magnesium $(\mathbf{M g}) \quad-$ & - & $\begin{array}{l}\text { Dissolved from almost all } \\
\text { soils and rocks in the } \\
\text { area. }\end{array}$ & $\begin{array}{l}\text { Second of the major causes } \\
\text { of hardness. }\end{array}$ \\
\hline $\begin{array}{l}\text { Sodium }(\mathrm{Na}) \\
\text { and } \\
\text { potassium }(\mathrm{K})\end{array}$ & 一 & 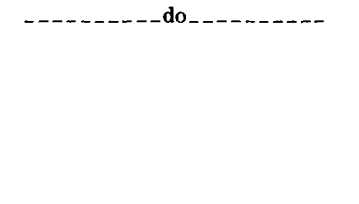 & $\begin{array}{l}\text { Large amounts in combination } \\
\text { with chloride may give } \\
\text { water a salty taste. Ex- } \\
\text { cessive amounts of sodium } \\
\text { may reduce soil permeability } \\
\text { and limit use of water for } \\
\text { irrigation. Potassium is } \\
\text { essential for proper plant } \\
\text { nutrition. }\end{array}$ \\
\hline $\begin{array}{l}\text { Bicarbonate } \\
\left.\text { ( } \mathrm{HCO}_{3}\right) \text { and } \\
\text { carbonate }\left(\mathrm{CO}_{3}\right)\end{array}$ & - & $\begin{array}{l}\text { Action of carbon dioxide } \\
\text { in water on carbonate } \\
\text { minerals. }\end{array}$ & $\begin{array}{l}\text { Causes carbonate hardness } \\
\text { in combination with cal- } \\
\text { cium or magnesiur. } \\
\text { Bicarbonates of calcium } \\
\text { and magnesium desompose } \\
\text { in steam boilers ant hot- } \\
\text { water facilities to form } \\
\text { scale and release ccrrosive } \\
\text { carbon dioxide gas. }\end{array}$ \\
\hline Sulfate $\left(\mathrm{SO}_{4}\right)$ & 250 & $\begin{array}{l}\text { Gypsum, iron sulfides, and } \\
\text { other sulfur compounds. } \\
\text { Commonly present in } \\
\text { many industrial wastes. }\end{array}$ & $\begin{array}{l}\text { Sulfates of calcium and } \\
\text { magnesium form hard scale } \\
\text { and are cathartic and } \\
\text { unpleasant to taste. }\end{array}$ \\
\hline Chloride (Cl) & 250 & $\begin{array}{l}\text { Chloride salts, largely } \mathrm{NaCl} \text {, } \\
\text { in the consolidated rocks } \\
\text { of marine origin. }\end{array}$ & $\begin{array}{l}\text { In high concentratiors has } \\
\text { salty taste and mal es } \\
\text { water corrosive. }\end{array}$ \\
\hline Fluoride (F) & $0.8-1.7$ & $\begin{array}{l}\text { Occurs in trace amounts in } \\
\text { most of the soils and } \\
\text { rocks. }\end{array}$ & $\begin{array}{l}\text { Optimum concentrations tend } \\
\text { to reduce decay of children's } \\
\text { teeth; larger amourts may } \\
\text { cause mottling of the } \\
\text { enamel of teeth. Ccn- } \\
\text { centrations of more than } \\
4 \mathrm{mg} / 1 \text { may affect bone } \\
\text { structure. }\end{array}$ \\
\hline Nitrate $\left(\mathrm{NO}_{3}\right)$ & 45 & $\begin{array}{l}\text { Decayed organic matter, } \\
\text { sewage, and nitrates in } \\
\text { soil. }\end{array}$ & $\begin{array}{l}\text { Values higher than lccal } \\
\text { average may suggest pollu- } \\
\text { tion. An excess of } 45 \mathrm{mg} / 1 \\
\text { in drinking water may } \\
\text { cause cyanosis, the so-called } \\
\text { "blue baby" disease in } \\
\text { infants. }\end{array}$ \\
\hline Boron (B) & 一 & $\begin{array}{l}\text { Occurs in trace amounts in } \\
\text { some of the rocks in the } \\
\text { area. }\end{array}$ & $\begin{array}{l}\text { Essential in small amounts for } \\
\text { proper plant nutrition. } \\
\text { Unsuitable in quantities of } \\
\text { more than } 3.75 \mathrm{mg} / 1 \text { for } \\
\text { even the most tolerant } \\
\text { crops. }\end{array}$ \\
\hline Arsenic (As) & .01 & $\begin{array}{l}\text { Associated locally with the } \\
\text { Fisher Formation. }\end{array}$ & $\begin{array}{l}\text { Prolonged consumption of } \\
\text { water containing nore } \\
\text { than } 0.05 \mathrm{mg} / 1 \text { of arsenic } \\
\text { may lead to chronis } \\
\text { poisoning. }\end{array}$ \\
\hline
\end{tabular}

1 U.S. Public Health Service (1962). 
ent recharge-discharge regimen, the minimum recharge can be considered as the perennial yield ${ }^{1}$ of the area. The $19 \epsilon^{\circ}$ pumpage for all uses $(23,000$ acre-ft) was about 23 percent of the perennial yield, leaving about 77,000 acre-feet of water available for additional withdrawal. The actual volume available should be somewhat greater than 77,000 acre-feet because some of the water pumped is not consumptively used but is returned to the aquifer by infiltration.

Increasing pumpage to the perennial yield $(100,070$ acre-ft) would have only a slight effect on the flow of the McKenzie and Willamette Rivers. Some decrease in flow of small streams might occur because their flow is mostly from ground water, particularly during low-flow periods. However, withdrawal of 100,000 acre-feet of ground water would have a negligible effect on the flow of the Willamette River because that volume of water is loss than 1 percent of the annual flow at Harrisburg (fig. 4). In addition, some of this water is lost naturally by evapotranspiration in the area. Increased pumping for irrigation would reduce this loss and at the same time allow percolation of some of the pumped water to the ground-water reservoir and eventually to the river.

Hydrographs of wells in the area (fig. 10) show that the groundwater reservoir in the central lowland is replenished each year, an indication that, in general, recharge balances discharge. In the future, a maximum volume of water can be developed from the central lowland by increasing the volume of recharre through greater use of the reservoir. Increased use of the reservoir would lower water levels. As water levels drop, discharge from the ground-water reservoir by evapotranspiration from the water table would decrease, as would discharge through seeps and springs. As the annual volume of water withdrawn is increased, the water level in the reservoir would adjust downward. Although the level of the ground-water reservoir might be changed permanently and natural discharge reduced, an increase in withdrawals could be accommodated without progressive losses in storage once the new equilibrium is established. Because the water table reaches its highest level in midwinter and then declines due to seepage from the ground-water reservoir, the greater seasonal drawdown of water levels should provide more storag? space for recharge. This should extend the period of recharge because a longer time would be needed to replenish the aquifer. With a longer recharge period, midwinter seepage loss would be reduced

\footnotetext{
1 Perennial yield is here defined as that volume of pumpage equal to the estimated minimum natural annual recharge to the aquifer of the central lowland.
} 
and part of the February to April precipitation that is rojected under the present stage of development would infiltrate to recharge the aquifer.

In the central lowland about 2.2 million acre-feet of manageable water is stored in the 10- to 150-foot zone below land surface. This large reservoir could carry over large quantities of water from a wet season to a dry season and from a period of wet years to a period of dry years. However, to utilize the reservoir fully, it would be necessary to pump enough water out of it to make room for the infiltration of precipitation during the wettest periods.

As indicated on page 25, the volume of ground water available could be further increased by constructing wells in places where they would induce infiltration from the Willamette and McKenzie Rivers. Water developed in this manner would come from the streams and would reduce their flows during the low-flow season.

\section{ANTICIPATED GROUND-WATER PROBLEMS}

Although additional ground water can be made available for use in the area, increased withdrawals may result in certain problems. Problems associated with, but not directly related to, increased pumping may result from current methods of waste disposal. The most common problems that can be anticipated from past and present experience in developing ground-water supplies are (1) contamination of ground water, (2) local interference between pumping wells, (3) local overdraft, and (4) improper well construction. Data in this report constitute a basis for evaluating some of the factors relating to foreseeable problems but allow only tentative conclusions to be drawn about factors such as rate and direction of movement of water. Additional information that can be obtained through continued systematic study will be needed to understand and solve these problems.

\section{CONTAMINATION OF GROUND WATER}

In much of the area, including the densely populated sul urban districts of Eugene and Springfield, household and other wastes are discharged into cesspools and septic tanks. Contamination of ground water from these sources may become a serious problem in the future, especially in areas where the water table is near the surface. Danger of contamination from these and other sources at or near the land surface may be increased in districts where precipitation, which normally would percolate downward and dilute the wastes, is largely intercepted by buildings, pavement, and storm drains. 
Additional detailed hydrologic information is needed to determine areas of potential ground-water contamination. A monitoring program of periodic sampling and analysis would aid in identifying and tracing contaminants and developing methods for controlling contamination. Additional information on the magnitude and areal distribution of transmissivity and storage also would be useful. Because of differences in vertical permeability, as discussed in the section on "Transmissivity and s'orage Coefficient," long-term aquifer tests are desirable and should yield more accurate results than do short-term tests.

\section{WELL INTERFERENCE}

Until the late 1940's, most of the agricultural land in the area was devoted to the production of nonirrigated crops such as wheat, barley, and various types of grass seed. The ferv irrigation wells in the area were shallow, and pump intakes were set only a few feet below the water table. These wells were generally dependable as long as there were only a few scattered wells in the vicinity. In recent years, the trend in crop production has been toward specialization, including crops such as vegetables and fruit, many of which require irrigation. Since the late 1940's. additional wells have been drilled, many of which are shallow, and subsequent increased pumping has caused water levels to decline below pump settings in many of the wells. If yields are to ke sustained at present rates, pumps may have to be lowered and wells deepened. Well interference is a problem throughout much of the valley plain where there is intensive localized pumping of water for irrigation from wells tapping the same shallow water-bearing zones. Although interference between wells cannot be avoided if the ground-water reservoir is to be fully utilized, interference can be minimized in areas of concentrated pumping by spacing wells as far apart as possible and by drilling wells deep enough to utilize all the available water-bearing zones.

\section{LOCAL OVERDRAFT}

At present, no problems of overdraft exist in the alluvial aquifers of the valley plain. However, the water-level maps (pl. 3) indicate a pumping depression in the southwestern part of T. 17 S., R. $3 \mathrm{~W}$. Locally in that area, the withdrawal of water may exceed the natural recharge and cause a slight perennial decline. This depression is in and near downtown Eugene, where recharge is naturally small and is probably diminishing because of buildings, paving, and construction of storm drains in natural infiltra- 
tion areas. Another area where the water-level maps suggest a slight pumping depression is in T. 17 S., R. 5 W., near the city of Veneta. Here there is an indicated low or depression near tre wells used by the city for municipal water supply. Any long-term declines that may occur in other parts of the study area are expected to be of local rather than widespread extent.

Water levels of wells in which withdrawals are now or are likely to become intensive should be measured on a continuing kasis to provide data for relating water-level changes to pumpage. This would be especially desirable in districts such as downtown Eugene and other parts of the area where alluvial materials are thin or largely nonexistent and where the principal aquifer materials consist largely of the older consolidated sedimentary rocks. Periodically, water-level maps should be revised to detect areas of depression and overdraft of the aquifers.

\section{WELL CONSTRUCTION}

To obtain efficiently the maximum quantities of ground water available from the alluvial aquifers, refinements in present well construction will be necessary. Many wells in the area do not yield as much water as is needed; many others yield the volumes needed but have large drawdowns that result in increased pumping costs. Some of the low-yield wells could have produced an adequate yield if they had been properly constructed and developed.

Because alluvial deposits that make up the central lowland consist of loose or slightly consolidated sand and gravel and associated silt and clay, a slotted casing or screen is needed to keep the well open and permit water to enter. The casing should hold back the formation and not allow appreciable interference with flow of water into the well. Many wells, because of inadequate openings in the casing or because they draw all their water through the open bottom of the casing, yield only a small quantity of the water that the aquifer could otherwise produce.

To obtain maximum yield, wells must be constructed to tap more of the available fine-grained water-bearing zones. Many water-bearing zones consisting primarily of sand and the finest layers are bypassed because well-construction methods presently being used cannot prevent sand from entering with the water. As a result, wells yield only a small quantity of the water that could otherwise be obtained from the alluvial aquifers. In places, some wells that have been perforated opposite fine-grained zones pump moderate to troublesome quantities of sand and silt which can cause excessive wear to pumps and irrigation equipment. 
Use of well screens is the most efficient method of well construction in a fine-grained aquifer. A properly designed well screen acts as a permeable wall that allows water to enter the well readily at low velocity and prevents sand from entering with the water. The screen slot size is selected on the basis of the size and size distribution of particles in the aquifer. In some wells, two or more slot sizes are used to screen aquifers of different particle sizes. An example of a properly constructed screened well is well 15S/4W-32cab4, drilled for municipal supplies of Jun tion City (tables 7,8 ). In this well, the well screen was placed in fine materials near the bottom of the well. Upon completion, the well was pump tested at $940 \mathrm{gpm}$ with about 38 feet of drawdcwn.

Another common method of well construction, but one not being generally used in the area, involves the use of an artificial screen and envelope of gravel around the screen or the perforated parts of the casing. The gravel increases the effective well diameter and prevents the fine materials from entering the well. A gravelpacked well properly constructed in a sand and gravel aquifer generally has a higher specific capacity than does a vell of the same diameter not surrounded by gravel. To be effective, an envelope of 3-6 inches of gravel is usually required. Gravel used in packing a well should be of a size that will retain most of the formation materials, and a well-screen opening should be of a selected size to retain the gravel pack. Therefore, the proper grain-size distribution for a gravel pack should be related to the grain size of the materials making up the aquifer and to the perforation or screen slot size.

Upon completion of drilling, a properly constructed vell should be developed to bring it to its maximum yield capacity. Proper development tends to correct any damage to or clogging of the water-bearing formation as a result of drilling and alsc increases porosity and permeability of the aquifer in the vicinity of the well. Consequently, water can move through this zone toward the well with smaller loss of head, which results in reduced drav'down and increased yield. Development should continue until the movement of fine material through the formation ceases and the well is sand free. Among methods commonly used to develop a well are pumping at progressively higher rates and surging by use of either (1) intermittent pumping, (2) surge blocks, or (3) compressed air. Well-development and well-construction methods are described in a publication by Edward E. Johnson, Inc. (1966), as well as in many other publications. 


\section{SUMMARY AND CONCLUSIONS}

The principal conclusions resulting from this study are:

1. Ground water is generally available for domestic use throughout the valley-fringe and upland parts of the EugeneSpringfield area. However, the volumes of water that can be developed from the consolidated sedimentary and volcanic rocks that make up these parts of the area vary considerably from place to place. The unconsolidated deposits that underlie the valley plain are the most productive aquifers and the only ones feasible for large-scale development of ground water in the area. The volume of ground water available from these aquifers could be increased by constructing wells where they would induce infiltration from the Willamette and McKenzie Rivers.

2. Most streamflow that enters the area is from precipitation that occurs upstream from the project area. The average annual inflow of surface water to the area is in ercess of 8 million acre-feet. Although stream-outflow patterns are similar to stream-inflow patterns, there is an annual gain in streamflow through the project area of about 5 percent. The comparatively small diversions of surface water for irrigation and municipal and domestic uses have little effect on the flow of the Willamette River.

3 . Water levels of the younger alluvial deposits are closely related to stream-stage fluctuations of the adjacent McKenzie and Willamette Rivers, and water moves from one environment to another. In the older alluvial deposits a few miles from the river, the effects of streamftow are not apparent, and ground-water levels have little relationship to river stages.

4. Precipitation is the principal source of recharge to the alluvial aquifer in the central lowland. Annual ground-water replenishment from infiltration in that part of the area in 1969-70 equaled about 13 inches, or 100,000 acre-feet, of water.

5. The storage capacity of the reservoir between depths of 10-150 feet below land surface is estimated to be about 2.1 million acre-feet. The annual change in ground-water storage or net annual recharge is estimated to be about 100,000 acrefeet, of which about 23,000 acre-feet is pumped from wells. Water-level records of previous years show that annual fluctuations in water level have been in the same range for 
many years-an indication that, in general, recharge balances discharge.

6. Because natural ground-water discharge in the area far exceeds withdrawals, the reservoir could support, greater pumping withdrawals. By increased pumping (a.) part of the water lost by natural discharge could be salvaged and the accompanying lowering of the water table could provide additional storage space for infiltration of pracipitation during wet periods, (b) recharge would be increased so that withdrawals of as much as 100,000 acre-feet could be developed that would have a negligible effect on streamflow, and (c) water levels in the ground-water reservoir would be lowered, the result being the establishment of a new equilibrium; the increased withdrawals could be accommodated without progressive losses to reservoir storage.

7. Chemical quality of water from the alluvial deposits is generally satisfactory for most uses, and the dissolved-solids content of water samples analyzed ranged from 24 to 382 $\mathrm{mg} / \mathrm{l}$. The water has a low-sodium and low-salinity hazard and is suitable for irrigation. Water from the olcer marine sedimentary rocks is more highly mineralized and has greater concentrations of calcium and chloride than does most other ground water in the area. Its disso'ved-solids content is usually greater than $500 \mathrm{mg} / \mathrm{l}$. Water from some of the wells in the Fisher Formation contains high concentrations of arsenic, ranging from 0.05 to $0.50 \mathrm{mg} / \mathrm{l}$.

8. To obtain maximum quantities of ground water available from the alluvial aquifers, wells must be constructed tc tap more of the available water-bearing zones that contain large quantities of fine sand. To utilize parts of the aquifers containing fine materials, it will be necessary to construct wells using a properly designed well screen and (or) a gravel pack around the screen or perforated parts of the casing.

9. Increased ground-water development in the area vill be accompanied by certain problems, such as well interference and local overdraft. Problems also could result frcm current practices of underground disposal of household sewage, which may enter pumping wells or be induced to move greater distances laterally by greater pumping. Data in this report provide a basis for evaluating some factors relevant to foreseeable problems but allow only tentative conclusions to be drawn about other factors. Additional information, that can be obtained through continuing and systemative study, will be needed to solve these problems. 


\section{WELL-NUMBERING SYSTEM}

Designations of wells discussed in this report are based on the official system for rectangular subdivision of public lands. The well number indicates the location of the well or test role by township, range, section, and its position within the section. A graphic illustration of this method of well numbering is shown in figure 12. The first numeral indicates the township; the second, the range; and the third, the section in which the well is located. The letters following the section number locate the well within the section. The first letter denotes the quarter section ( 160 acres); the second, the quarter-quarter section (40 acres); and the third, the quarter-quarter-quarter section (10 acres). For example, well $16 \mathrm{~S} / 5 \mathrm{~W}-16 \mathrm{bcc}$ is in $\mathrm{SW} 1 / 4, \mathrm{SW} 1 / 4 \mathrm{NW} 1 / 4$ sec. $16, \mathrm{~T}$. $16 \mathrm{~S} .$, R. $5 \mathrm{~W}$. Where two or more wells are in the same 10 -acre subdivision, serial numbers are added after the third letter.

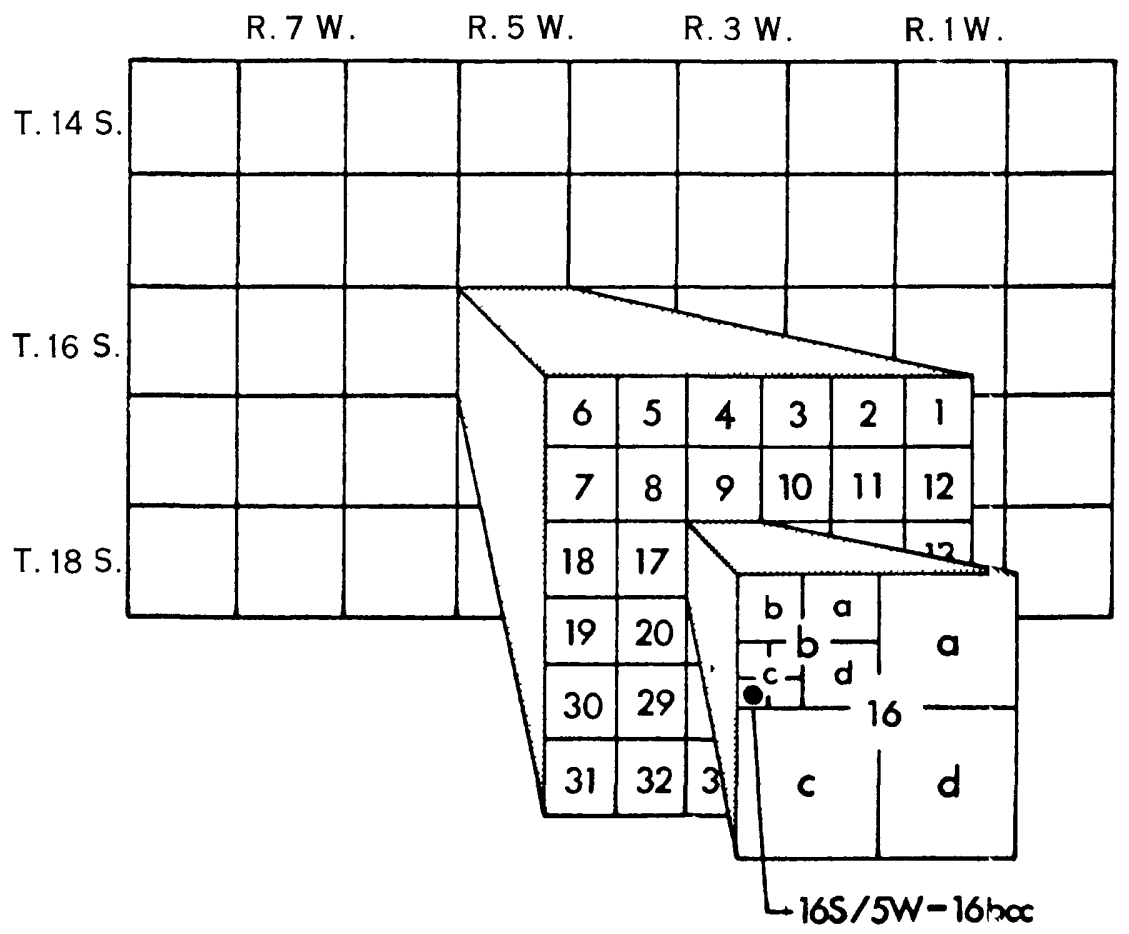

Figure 12.-Well-numbering system. 


\section{BASIC GROUND-WATER DATA}

Table 7 contains lithologic logs of representative wells drilled in the study area. Nearly all the logs were obtained frcm drillers' reports submitted to the Oregon State Engineer. The renorts were edited for consistency of terminology and for conformance with the stratigraphic units described in the text but are otherwise unchanged.

Data summarized in table 8 are representative of ground-water data collected in the study area during this investigation. Well records shown in table 8 were obtained from reports compiled by well drillers and from well owners and operators.

The locations of wells listed in the tables are shown on plate 1 . Most of the data collected in the study area have been published by the Oregon State Engineer (Frank and Johnson, 1970). Additional unpublished ground-water data, including well reports and ground-water-level records, are on file in the offices of the Oregon State Engineer, Salem, Oreg., and the U.S. Geological Survey, Portland, Oreg.

TABLE 7.-Drillers' logs of representative wells

\begin{tabular}{|c|c|c|c|c|c|}
\hline Materials & $\begin{array}{c}\text { Thickness } \\
\text { (feet) }\end{array}$ & $\begin{array}{c}\text { Depth } \\
\text { (feet) }\end{array}$ & Materials & $\begin{array}{c}\text { Tl ickness } \\
\text { (feet) }\end{array}$ & $\begin{array}{l}\text { Depth } \\
\text { (feet) }\end{array}$ \\
\hline
\end{tabular}

\section{$15 \mathrm{~S} / 3 \mathrm{~W}-28 \mathrm{cab}$}

[Oregon State Highway Comm. Alt $342 \mathrm{ft}$. Drilled by J. A. Sneed \& Sons, 1961. Casing: 6 -in. diam to $62 \mathrm{ft}$; perforated $34-54 \mathrm{ft}]$

\begin{tabular}{|c|c|c|c|c|c|}
\hline $\begin{array}{l}\text { Soil } \\
\text { Older alluvium: } \\
\text { Conglomerate } \\
\text { Sand and gravel, water- } \\
\text { bearing } \\
\text { Conglomerate } \\
\text { Sand and gravel, water- } \\
\text { bearing }\end{array}$ & $\begin{array}{r}2 \\
17 \\
1 \\
14\end{array}$ & $\begin{array}{l}19 \\
20 \\
34\end{array}$ & $\begin{array}{l}\text { Older alluvium-Continued } \\
\text { Conglomerate, water- } \\
\text { bearing } \\
\text { Eugene(?) Formation: } \\
\text { Clay, blue } \\
\text { Clay, green } \\
\text { Claystone, gray }\end{array}$ & $\begin{array}{l}19 \\
10 \\
15\end{array}$ & $\begin{array}{r}80 \\
90 \\
105\end{array}$ \\
\hline
\end{tabular}

$15 \mathrm{~S} / 4 \mathrm{~W}-28 \mathrm{bad} 2$

[O. K. Peterson. Alt $320 \mathrm{ft}$. Drilled by Christensen Drilling \& Irrigation, 1967. Casing: 10 -in. diam to $34 \mathrm{ft}$; perforated $22-33 \mathrm{ft}]$

\begin{tabular}{|c|c|c|c|c|c|}
\hline $\begin{array}{l}\text { Soil } \\
\text { Younger alluvium: } \\
\text { Sand and gravel }\end{array}$ & $\begin{array}{c}6 \\
171 / 2\end{array}$ & $\begin{array}{c}6 \\
231 / 2\end{array}$ & $\begin{array}{l}\text { Younger alluvium-Continued } \\
\text { Sand and gravel, loose, } \\
\text { water-bearing } \\
\text { Older alluvium: } \\
\text { Clay, sandy, blue }\end{array}$ & $\begin{array}{l}10 \\
1 / 2\end{array}$ & $\begin{array}{l}331 / 2 \\
34\end{array}$ \\
\hline
\end{tabular}

$15 \mathrm{~S} / 4 \mathrm{~W}-32 \mathrm{cab} 4$

[City of Junction City. Alt $325 \mathrm{ft}$. Drilled by W. W. Drilling \& Pump Service, 1968. Casing:

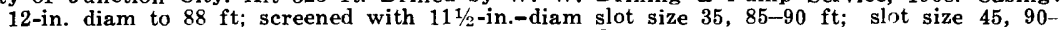
$96 \mathrm{ft}$; slot size 20, 96-111 ft; slot size 30, 111-125 ft]

Older alluvium:

Clay, brown -........ 11

Sand and clay, loose
Older alluvium-Continued

Sand and small-sized gravel 
TABLE 7.-Drillers' logs of representative wells-Continued

\begin{tabular}{|c|c|c|c|c|}
\hline Materials & $\begin{array}{c}\text { Thickness } \\
\text { (feet) }\end{array}$ & $\begin{array}{l}\text { Depth } \\
\text { (feet) }\end{array}$ & Materials & $\begin{array}{c}\text { Thickness Depth } \\
\text { (feet) (feet) }\end{array}$ \\
\hline
\end{tabular}

\section{S/4W-32cab4-Continued}

\begin{tabular}{|c|c|c|c|c|c|}
\hline $\begin{array}{l}\text { der alluvium-Continued } \\
\text { Sand and gravel, tight } \\
\text { Sand and small gravel --- } \\
\text { Sand and gravel, cemented } \\
\text { Clay, light-brown, sandy, } \\
\text { and some gravel } \\
\text { Clay, brown, sandy } \\
\text { Sand, brown -- } \\
\text { Clay, brown, sandy } \\
\text { Clay, blue }\end{array}$ & $\begin{array}{r}6 \\
11 \\
2 \\
5 \\
10\end{array}$ & $\begin{array}{l}42 \\
53 \\
55 \\
60 \\
70\end{array}$ & $\begin{array}{l}\text { Older alluvium-Continued } \\
\text { Sand, blue } \\
\text { Sand, blue, and wood } \\
\text { Sand, blue, and pea gravel } \\
\text { Sand, blue, and some gravel } \\
\text { and clay } \\
\text { Sand, blue } \\
\text { Gravel, small, and blue } \\
\text { sand and wood } \\
\text { Clay, blue, sandy }\end{array}$ & $\begin{array}{r}8 \\
16 \\
4\end{array}$ & $\begin{array}{l}78 \\
\mathbf{9 4} \\
98\end{array}$ \\
\hline
\end{tabular}

\section{$15 \mathrm{~S} / 4 \mathrm{~W}-32 \mathrm{cab} 1$}

[City of Junction City. Alt $325 \mathrm{ft}$. Drilled in 1938. Casing: 8-in. diam to $148 \mathrm{ft}$; perforated $138-148 \mathrm{ft}]$

\begin{tabular}{|c|c|c|c|c|c|}
\hline $\begin{array}{l}\text { Soil } \\
\text { Older alluvium: } \\
\text { Clay, brown } \\
\text { Clay and gravel and and sand; clayey at } \\
\text { Gravel and } \\
\text { bottom, water-bearing--- } \\
\text { Clay, brown and blue } \\
\text { Sand, coarse, and soft brown } \\
\text { clay; water bearing } \\
\text { Clay, blue --- } \\
\text { Sand, fine gravel, and blue- } \\
\text { gray clay; water bearing }\end{array}$ & $\begin{array}{r}2 \\
6 \\
7 \\
16 \\
7 \\
22 \\
8 \\
132\end{array}$ & $\begin{array}{l}60 \\
68\end{array}$ & $\begin{array}{l}\text { Sedimentary rocks of Tertiary age, } \\
\text { differentiated: } \\
\text { Clay, blue-gray, and sand } \\
\text { Shale, blue-gray and brown } \\
\text { Sandstone, blue-gray, soft; } \\
\text { yields a little, water -- } \\
\text { "Cement gravel" (agglomerat } \\
\text { or conglomerate) } \\
\text { Shale, brownish-gray; lower } \\
\text { part sandy ,- very light } \\
\text { "Conglomerate," veray, hard } \\
\text { gray,--oway -- } \\
\text { Shale, brownish-gray }\end{array}$ & $\begin{array}{l}\text { un- } \\
33 \\
47 \\
70 \\
\text { te } \\
17 \\
63\end{array}$ & $\begin{array}{l}233 \\
280\end{array}$ \\
\hline
\end{tabular}

$16 S / 2 W-27 d c d 1$

[Mohawk Packing Co. Alt $500 \mathrm{ft}$. Drilled by Christensen Drilling \& Irrigation, 1964. Casing: 6-in. diam to $83 \mathrm{ft}$; unperforated ]

\begin{tabular}{|c|c|c|c|c|c|}
\hline $\begin{array}{l}\text { Soil } \\
\text { Older alluvium: } \\
\text { Clay and boulders } \\
\text { Clay and some gravel; small } \\
\text { quantity of water } \\
\text { Gravel and weathered } \\
\text { sandstone }\end{array}$ & $\begin{array}{r}7 \\
8 \\
13 \\
32\end{array}$ & $\begin{array}{l}15 \\
28\end{array}$ & $\begin{array}{l}\text { Older alluvium-Continued } \\
\text { Gravel and weathered } \\
\text { "material"; sticky } \\
\text { Gravel and weathered } \\
\text { sandstone - } \\
\text { Gravel and some clay } \\
\text { Gravel and blue clay }\end{array}$ & $\begin{array}{r}40 \\
18 \\
2\end{array}$ & $\begin{array}{l}105 \\
123 \\
125\end{array}$ \\
\hline
\end{tabular}

\section{$16 S / 3 \mathrm{~W}-30 \mathrm{dba}$}

[S. K. Coburn. Alt $370 \mathrm{ft}$. Drilled by W. W. Drilling \& Pump Service, 1967. Casing : 10 -in. diam to $231 \mathrm{ft}$; perforated $18-230 \mathrm{ft}$ ]

\begin{tabular}{|c|c|c|c|c|c|}
\hline $\begin{array}{l}\text { Soil } \\
\text { Younger alluvium: } \\
\text { Clay, brown, and gravel } \\
\text { Gravel and boulders } \\
\text { Older alluvium: } \\
\text { Clay, brown, and sand and } \\
\text { gravel; some water } \\
\text { Clay, brown, and sand and } \\
\text { gravel }\end{array}$ & $\begin{array}{l}9 \\
4\end{array}$ & $\begin{array}{l}16 \\
20\end{array}$ & $\begin{array}{l}\text { Older alluvium-Continued } \\
\text { Clay, blue-gray, and small- } \\
\text { sized gravel - } \\
\text { Clay, gray, and small-sized } \\
\text { gravel } \\
\text { Clay, yellow-brown } \\
\text { Clay, gray-white } \\
\text { Sand and gravel } \\
\text { Clay, blue }\end{array}$ & $\begin{array}{r}25 \\
10 \\
25 \\
18 \\
3\end{array}$ & $\begin{array}{l}175 \\
185 \\
210 \\
228 \\
231\end{array}$ \\
\hline
\end{tabular}

\section{$16 S / 4 \mathrm{~W}-6 \mathrm{bad}$}

[Dean McKay, Alt $320 \mathrm{ft}$. Drilled by Casey Jones Well Drilling Co., 1967. Casing: 6 -in. diam to $85 \mathrm{ft}$; unperforated]

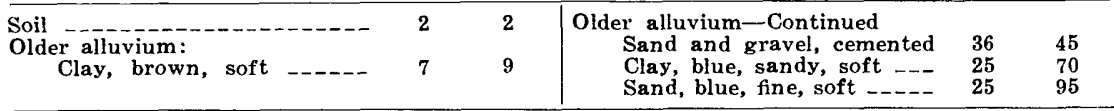


TABLE 7.-Drillers' logs of representative wells-Continued

\begin{tabular}{|c|c|c|c|c|c|}
\hline Materials & $\begin{array}{c}\text { Thickness } \\
\text { (feet) }\end{array}$ & $\begin{array}{c}\text { Depth } \\
\text { (feet) }\end{array}$ & Materials & $\begin{array}{c}\text { Thickness } \\
\text { (feet) }\end{array}$ & $\begin{array}{l}\text { Depth } \\
\text { (feet) }\end{array}$ \\
\hline
\end{tabular}

\section{$16 S / 4 W-16 c a d$}

[Shadow Hills Golf Course. Alt $340 \mathrm{ft}$. Drilled by W. W. Drilling \& Pump Service, 1962. Casing: 10 -in. diam to $240 \mathrm{ft}$; perforated $20-34 \mathrm{ft}$ and $58-162 \mathrm{ft}]$

Soil

Older alluvium:

Sand and gravel; contains clay

Sand and gravel, water-

bearing

Gravel, cemented

Claystone, blue

Clay, blue; contains gravel,

water bearing in places.

$\begin{array}{rr}8 & 8 \\ 8 & 16 \\ 9 & 25 \\ 9 & 34 \\ 24 & 58 \\ 44 & 102\end{array}$

Older alluvium-Continued

Sand, blue, and gravel,

water-bearing

Claystone, blue; water

bearing in places _-- $49 \quad 459$

Clay, blue, and gravel,

water-bearing _...-. $\quad 3 \quad 162$

Clay, gray, sticky, caving- $20 \quad 182$

Clay, yellow, gray-streaked $48 \quad 230$

Clay, blue, brown-streaked_ $20 \quad 250$

\section{S/5W-10bdb1}

[Neil Cheshire. Alt 328 ft. Drilled by C. E. Gordinier \& Son Drilling Co., 1968. Casing: 6-in. diam to $124 \mathrm{ft}$; unperforated ]

Clay, blue

Older alluvium:

Gravel, fine and round,

and blue clay

Gravel, medium

Gravel and brown clay

$\begin{array}{rr}6 & 6 \\ & \\ 12 & 18 \\ 16 & 34 \\ 34 & 68\end{array}$

Spencer Formation:

Sandstone, yellow _-___ $\quad 1 \quad 69$

Rock, sedimentary, blue - $\quad 1 \quad 70$

Clay, blue _-

Rock, sedimentary, blue - 78 198

\section{$16 S / 6 W-36 a d d$}

[W. C. Van Dusen. Alt 775 ft. Drilled by O. B. Nye, 1961. Casing: 5-in. ciam to $40 \mathrm{ft}$; unperforated]

\begin{tabular}{lrl|rrr}
\hline Spencer Formation: & & Spencer Formation-Continued \\
Clay, red & & 42 & Claystone, gray, sandy --- & 90 \\
Shale, red --142 \\
Clay, red
\end{tabular}

\section{$17 \mathrm{~S} / 2 \mathrm{~W}-9 \mathrm{bca}$}

[C. L. Howard. Alt $575 \mathrm{ft}$. Drilled by Casey .Jones Well Drilling Co., 1967. Casing: 6-in. diam to $18 \mathrm{ft}$; unperforated]

\begin{tabular}{|c|c|c|c|c|}
\hline $\begin{array}{l}\text { Soil } \\
\text { Little Butte Volcanic Series: } \\
\text { Sandstone, blue } \\
\text { Sandstone, blue-gray } \\
\text { Sandstone, blue } \\
\text { Rock, blue-brown } \\
\text { Sandstone, blue-gray }\end{array}$ & $\begin{array}{r}68 \\
116 \\
17 \\
8 \\
25\end{array}$ & $\begin{array}{r}74 \\
190 \\
207 \\
215 \\
240\end{array}$ & $\begin{array}{l}\text { Little Butte Volcanic Series-Continued } \\
\text { Sandstone, brown } \\
\text { Sandstone, blue } \\
\text { Rock, brown } \\
\text { Rock, blue }-\end{array}$ & $\begin{array}{l}305 \\
370 \\
385 \\
405 \\
415\end{array}$ \\
\hline
\end{tabular}

\section{$17 \mathrm{~S} / 2 \mathrm{~W}-26 \mathrm{cca} 2$}

[Springfield Utility Board. Alt $510 \mathrm{ft}$. Drilled by W. W. Drilling \& Pump Serrice, 1969. Casing : 16-in. diam to $56 \mathrm{ft}$; perforated 26-56 ft]

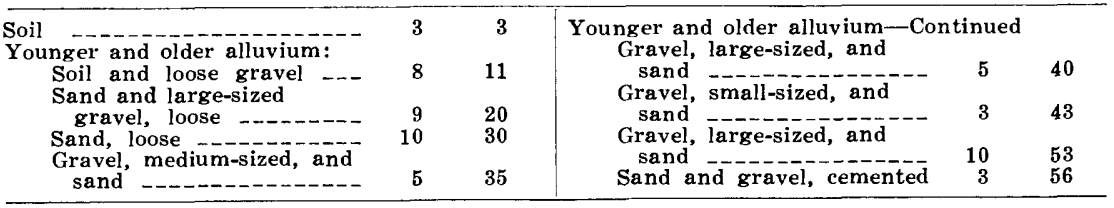


TABLE 7.-Drillers' logs of representative wells-Continued

\begin{tabular}{|c|c|c|c|c|c|}
\hline Materials & $\begin{array}{c}\text { Thickness } \\
\text { (feet) }\end{array}$ & $\begin{array}{c}\text { Depth } \\
\text { (feet) }\end{array}$ & Materials & $\begin{array}{c}\text { Thickness } \\
\text { (feet) }\end{array}$ & $\begin{array}{l}\text { Depth } \\
\text { (feet) }\end{array}$ \\
\hline
\end{tabular}

\section{$17 \mathrm{~S} / 3 \mathrm{~W}-5$ aaa}

[Leon Funke. Alt $398 \mathrm{ft}$. Drilled by W. W. Drilling \& Pump Service, 1969. Casing: 10-in. diam to $263 \mathrm{ft}$; perforated $18-263 \mathrm{ft}]$

\begin{tabular}{|c|c|c|c|c|c|}
\hline $\begin{array}{l}\text { Younger alluvium: } \\
\text { Loam and gravel } \\
\text { Sand and loose gravel } \\
\text { O.der alluvium: } \\
\text { Clay, sand, and gravel } \\
\text { Clay, brown, and sand and } \\
\text { gravel -- } \\
\text { Clay, yellowish-brown, and } \\
\text { sand and gravel } \\
\text { Clay, bluish-grav, and sand } \\
\text { and gravel } \\
\text { Clay, yellowish-brown, and } \\
\text { sand and gravel }\end{array}$ & $\begin{array}{r}6 \\
19\end{array}$ & $\begin{array}{r}6 \\
25\end{array}$ & $\begin{array}{l}\text { Older alluvium-Continued } \\
\text { Clay, gray, and sand and } \\
\text { gravel } \\
\text { Clay, blue, and sand and } \\
\text { gravel } \\
\text { Clay, brown, and sand } \\
\text { Clay, blue, sandy } \\
\text { Sand, coarse, and small- } \\
\text { sized gravel - } \\
\text { Clay, bluish-gray - } \\
\text { Clay, gray; sand and small- } \\
\text { sized gravel at bottom-- }\end{array}$ & $\begin{array}{l}27 \\
22 \\
22\end{array}$ & $\begin{array}{l}225 \\
247 \\
255\end{array}$ \\
\hline
\end{tabular}

$17 \mathrm{~S} / 3 \mathrm{~W}-5 \mathrm{cbb}$

[Eugene Water \& Electric Board. Alt $375 \mathrm{ft}$. Drilled by Christensen Drilling \& Ir-igation, 1969. Casing: 12-in. diam to $51 \mathrm{ft}$; unperforated]

\begin{tabular}{|c|c|c|c|c|c|}
\hline $\begin{array}{l}\text { Youngex alluvium: } \\
\text { Gravel, cobbles, and gray } \\
\text { sand } \bar{d} \text { pea-sized gravel- } \\
\text { Sand and } \\
\text { Older alluvium: } \\
\text { Gravel, cobbles, dirty sand, } \\
\text { and a few clay balls }----\end{array}$ & $\begin{array}{c}14 \\
1\end{array}$ & $\begin{array}{l}14 \\
15\end{array}$ & $\begin{array}{l}\text { Older alluvium-Continued } \\
\text { Gravel, cobbles, and fairly } \\
\text { clean sand - } \\
\text { Sand, cemented, and pea- } \\
\text { sized gravel } \\
\text { Gravel, sand, and clay } \\
\text { Gravel, pea-sized, and clean } \\
\text { sand, }\end{array}$ & $\begin{array}{l}1 \\
1\end{array}$ & $\begin{array}{l}49 \\
50 \\
51 \\
53\end{array}$ \\
\hline
\end{tabular}

\section{$17 \mathrm{~S} / 3 \mathrm{~W}-32 \mathrm{bbc}$}

[Eugene Fruit Growers Assoc. Alt 425 ft. Drilled by Wayne Hayes Well Drilling, 1957.

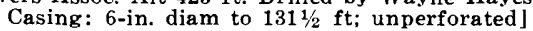

\begin{tabular}{|c|c|c|c|c|c|}
\hline $\begin{array}{l}\text { Soil and gravel } \\
\text { Older alluvium: } \\
\text { Gravel, clay, and sand, } \\
\text { compacted } \\
\text { Gravel and sand, loose, } \\
\text { water-bearing, } \\
\text { Sand and gravel, } \\
\text { compacted } \\
\text { Eugene Formation: } \\
\text { Clay, yellow-brown } \\
\text { Clay, blue-gray --- } \\
\text { Clay, yellow-brown, and } \\
\text { small-sized gravel } \\
\text { Clay, blue-gray ---- }\end{array}$ & $\begin{array}{l}12 \\
11 / 2 \\
61 / 2 \\
10 \\
79 \\
10 \\
6\end{array}$ & $\begin{array}{l}18 \\
191 / 2 \\
26 \\
36 \\
115\end{array}$ & $\begin{array}{l}\text { Eugene Formation-Continued } \\
\text { Sandstone, gray, tuffaceous } \\
\text { Sandstone, coarse; contains } \\
\text { some shells, water bear- } \\
\text { ing } \\
\text { Tuff, blue-gray, fine- } \\
\text { grained } \\
\text { Sandstone, gray, hard, coarse; } \\
\text { contains black shell } \\
\text { particles; water bearing } \\
\text { Rock, blue-gray, fine-grained; } \\
\text { has thin streaks of coarse } \\
\text { gray water-bearing sand- } \\
\text { stone at } 284 \text { and } 290 \mathrm{ft} \text {-- }\end{array}$ & $\begin{array}{c}9 \\
2 \\
\varepsilon 3\end{array}$ & $\begin{array}{l}208 \\
217\end{array}$ \\
\hline
\end{tabular}

$17 \mathrm{~S} / 4 \mathrm{~W}-3 \mathrm{acb}$

[Gordon Elliott. Alt $373 \mathrm{ft}$. Drilled by Christensen Drilling \& Irrigation, 1936. Casing: 10-in. diam to $212 \mathrm{ft}$; perforated 25-212 ft]

\begin{tabular}{|c|c|c|c|c|c|}
\hline $\begin{array}{l}\text { Older alluvium: } \\
\text { Silt and medium-sized } \\
\text { gravel } \\
\text { Clay and gravel } \\
\text { Gravel, medium-sized, loose, } \\
\text { water-bearing } \\
\text { Gravel and clay } \\
\text { Gravel, medium- and large- } \\
\text { sized, loose } \\
\text { Gravel, medium-sized, } \\
\text { cemented, and clay } \\
\text { Sand and brown clay; } \\
\text { cemented }\end{array}$ & $\begin{array}{r}9 \\
21 \\
6 \\
20 \\
25\end{array}$ & $\begin{array}{l}36 \\
56 \\
81\end{array}$ & $\begin{array}{l}\text { Older alluvium-Continued } \\
\text { Sand, medium-sized, water- } \\
\text { bearing } \\
\text { Gravel and clay } \\
\text { Gravel, small-sized; con- } \\
\text { tains sand and clay } \\
\text { Gravel, small-sized, and } \\
\text { sand; water bearing } \\
\text { Gravel, medium- and small- } \\
\text { sized, and sand; water- } \\
\text { bearing } \\
\text { Clay, blue, and gravel } \\
\text { Clay, blue }\end{array}$ & $\begin{array}{r}16 \\
3 \\
5\end{array}$ & $\begin{array}{l}212 \\
215 \\
220\end{array}$ \\
\hline
\end{tabular}


TABLE 7.-Drillers' logs of representative wells-Contirued

\begin{tabular}{cc|cc} 
Materials & $\begin{array}{c}\text { Thickness Depth } \\
\text { (feet) }\end{array}$ & $\begin{array}{c}\text { (feet) } \\
\text { (ferickness Depth } \\
\text { (feet) }\end{array}$ & Materials \\
\hline
\end{tabular}

\section{$17 \mathrm{~S} / 4 \mathrm{~W}-13 \mathrm{ccd}$}

[Peter Schmitz, Jr. Alt $400 \mathrm{ft}$. Drilled by R. E. MeTavish, 1959. Casing: 6-in. diam to $123 \mathrm{ft}$; perforated at unknown depth]

\begin{tabular}{|c|c|c|c|c|c|}
\hline $\begin{array}{l}\text { Soil } \\
\text { Older alluvium: } \\
\text { Gravel, cemented } \\
\text { Shale, blue }\end{array}$ & $\begin{array}{l}12 \\
58 \\
12\end{array}$ & $\begin{array}{l}12 \\
70 \\
82\end{array}$ & $\begin{array}{l}\text { Older alluvium-Continued } \\
\text { Gravel, cemented } \\
\text { Shale, blue } \\
\text { Gravel, cemented } \\
\text { Sand and clay }\end{array}$ & $\begin{array}{r}28 \\
3 \\
7 \\
3\end{array}$ & $\begin{array}{l}110 \\
113 \\
120 \\
123\end{array}$ \\
\hline
\end{tabular}

\section{S/4W-33aba1}

[West Lawn Memorial Cemetery. Alt $390 \mathrm{ft}$. Drilled by Wayne Hayes Well D illing, 1959. Casing: 6-in. diam to $54 \mathrm{ft}$; perforated $25-51 \mathrm{ft}$ ]

\begin{tabular}{|c|c|c|c|c|c|}
\hline $\begin{array}{l}\text { Soil der alluvium: } \\
\text { Clay and gravel, fairly } \\
\text { compact } \\
\text { Sand and gravel, water- } \\
\text { bearing }\end{array}$ & 17 & 25 & $\begin{array}{l}\text { Eugene Formation: } \\
\text { Clay } \\
\text { Sandstone, tuffaceous; water- } \\
\text { bearing at } 115 \mathrm{ft}\end{array}$ & $\begin{array}{r}3 \\
96\end{array}$ & $\begin{array}{r}54 \\
150\end{array}$ \\
\hline
\end{tabular}

\section{$17 \mathrm{~S} / 5 \mathrm{~W}-31 \mathrm{bcal}$}

[City of Veneta. Alt $410 \mathrm{ft}$. Drilled by Carter's Drilling \& Pump Service, 1967. Casing: 12 in. diam to $76 \mathrm{ft}, 10$-in. diam $72-79 \mathrm{ft}$ and $119-124 \mathrm{ft} ; 10$-in. screen, slot size $50,79-96$ $\mathrm{ft} ; 10$-in. screen, slot size $100,96-119 \mathrm{ft}]$

\begin{tabular}{|c|c|c|c|c|c|}
\hline $\begin{array}{l}\text { Soil } \\
\text { Older alluvium: } \\
\text { Clay, yellow } \\
\text { Sand and coarse gravel }\end{array}$ & $\begin{array}{r}4 \\
42 \\
11\end{array}$ & $\begin{array}{l}46 \\
57\end{array}$ & $\begin{array}{l}\text { Older alluvium-Continued } \\
\text { Sand, fine } \\
\text { Sand, coarse } \\
\text { Sand, coarse, and gravel - }\end{array}$ & $\begin{array}{r}7 \\
15 \\
45\end{array}$ & $\begin{array}{r}64 \\
79 \\
124\end{array}$ \\
\hline
\end{tabular}

TABLE 8.-Records of wells in

Well: See p. 49 for description of well-numbering system.

Type of well: Dr, drilled; Dv, driven.

Finish: B, open bottom (not perforated or screened); Sc, screened; P, perforated, numbers indicate depth of perforated intervals, in feet.

Altitude: Altitude of land surface at well, in feet above mean sea level, interpolated from topographic maps.

Water level: Depths to water below land surface given in feet, and decimals were measured by the U.S. Geological Survey; those in whole feet were reported by others or estimated. Specific conductance of water: Field determination, in micromhos at $25^{\circ} \mathrm{C}$.

\begin{tabular}{|c|c|c|c|c|c|c|c|c|c|c|}
\hline \multirow[b]{2}{*}{ Well } & \multirow[b]{2}{*}{ Owner } & \multirow[b]{2}{*}{$\begin{array}{c}\text { Type } \\
\text { of } \\
\text { well }\end{array}$} & \multirow{2}{*}{$\begin{array}{l}\text { Year } \\
\text { com- } \\
\text { pleted }\end{array}$} & \multirow{2}{*}{$\begin{array}{c}\text { Depth } \\
\text { of } \\
\text { well } \\
\text { (feet) }\end{array}$} & \multirow{2}{*}{$\begin{array}{l}\text { Diam- } \\
\text { eter of } \\
\text { well } \\
\text { (in.) }\end{array}$} & \multirow{2}{*}{$\begin{array}{l}\text { Depth } \\
\text { of } \\
\text { casing } \\
\text { (feet) }\end{array}$} & \multirow[b]{2}{*}{ Finish } & \multicolumn{3}{|c|}{ Water-bearing zone (s) } \\
\hline & & & & & & & & $\begin{array}{l}\text { Depth } \\
\text { to top } \\
\text { (feet) }\end{array}$ & $\begin{array}{l}\text { Trick- } \\
\text { ress } \\
\text { (feet) }\end{array}$ & $\begin{array}{c}\text { Character } \\
\text { of } \\
\text { material }\end{array}$ \\
\hline & & & & & & & & & & T. 15 S., \\
\hline 26 baa & $\begin{array}{c}\text { Walter } \\
\text { Holt. }\end{array}$ & Dr & 1949 & 60 & 6 & 一 & - & - & 一 & - \\
\hline $28 \mathrm{cab} \ldots$ & $\begin{array}{c}\text { Oregon } \\
\text { State } \\
\text { Highway } \\
\text { Comm. }\end{array}$ & $\mathrm{Dr}$ & 1961 & 105 & 6 & 62 & $P, 34-54$ & 20 & 30 & $\begin{array}{l}\text { Sand and } \\
\text { gravel. }\end{array}$ \\
\hline
\end{tabular}


TABLE 7.-Drillers' logs of representative wells-Continued

\begin{tabular}{|c|c|c|c|c|c|}
\hline Materials & $\begin{array}{c}\text { Thickness } \\
\text { (feet) }\end{array}$ & $\begin{array}{l}\text { Depth } \\
\text { (feet) }\end{array}$ & Materials & $\begin{array}{c}\text { Thickness } \\
\text { (feet) }\end{array}$ & $\begin{array}{l}\text { Depth } \\
\text { (feet) }\end{array}$ \\
\hline
\end{tabular}

\section{$18 \mathrm{~S} / 4 \mathrm{~W}-3 \mathrm{cad}$}

[Nils Hult. Alt $560 \mathrm{ft}$. Drilled by Christensen Drilling \& Irrigation, 1957. Casing: 6-in. diam to unknown depth; unperforated]

\begin{tabular}{|c|c|c|c|c|c|}
\hline $\begin{array}{l}\text { Fisher Formation: } \\
\text { Sandstone and clay, } \\
\text { weathered } \\
\text { Sandstone, blue-gray, } \\
\text { tuffaceous }\end{array}$ & 51 & 84 & $\begin{array}{l}\text { Fisher Formation-Continued } \\
\text { Sandstone, red, tuffaceous, } \\
\text { soft } \\
\text { Sandstone, blue-gray, } \\
\text { tuffaceous; no water } \\
\text { until } 230 \mathrm{ft}\end{array}$ & 119 & 122 \\
\hline
\end{tabular}

$18 S / 4 W-14 a c b$

「Ernest Muster. Alt $810 \mathrm{ft}$. Drilled by Christensen Drilling \& Irrigation, 1959. Casing: 5-in, diam to $334 \mathrm{ft}$; unperforated]

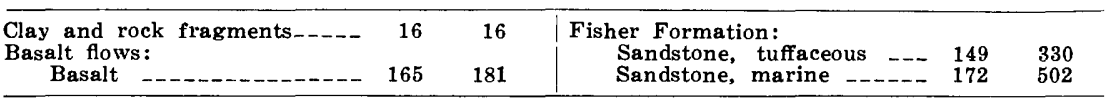

\section{$18 \mathrm{~S} / 5 \mathrm{~W}-9 \mathrm{bba} 1$}

[Central Schoo'. Alt $400 \mathrm{ft}$. Drilled by Christensen Drilling \& Irrigation, 1966. Casing: 6-in. diam to $18 \mathrm{ft}$; unperforated ]

Older alluvium and terrace deposits Soil and sandy clay _-- i1 Clay, light-gray, soft -- 11

Clay, light-gray, hard --- 1

Clay, light-gray, soft $-\ldots \quad 10$

Clay, very dark gray,

soft 61

Clay, light-gray, fine -- $14 \quad 108$

Sedimentary rocks of Tertiary age, undifferentiated:

Shale, dark-brown _._.. 11109

Shale, light-gray, large-

grained 11110

Shale, light-gray, soft,

sandy - $10 \quad 120$

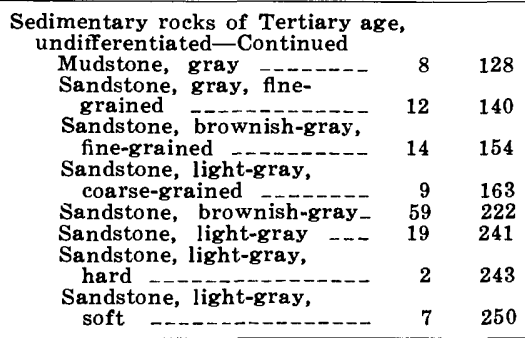

\section{the Eugene-Springfield area}

Type of pump: C, centrifugal; J, jet; S, submersible; P, piston; T, turbine; H, hand; N, none.

Well performance: Yield, in gallons per minute, and drawdown, in feet below nondischarging water level, reported by owner, operator, driller, or pump company.

Use: D, domestic; PS, public supply; Ir, irrigation; In, industrial; T, test; N, none.

Remarks: Ca, chemical analysis of water in table 5; H, hydrograph in flgure indicated; $L$, drillers' log of well in table 7; $\mathrm{P}$ or $\mathrm{B}$, pumped or bailed, for the indicated rumber of hours, when drawdown was measured. Remarks on adequacy, dependability, and general quality are reported by owners, tenants, drillers, or others.

\begin{tabular}{|c|c|c|c|c|c|c|c|c|}
\hline \multirow[b]{2}{*}{$\begin{array}{l}\text { Alti- } \\
\text { tude } \\
\text { (feet) }\end{array}$} & \multicolumn{2}{|c|}{ Water level } & \multirow[b]{2}{*}{$\begin{array}{l}\text { Speciflc- } \\
\text { conduct- } \\
\text { ance } \\
\text { of water }\end{array}$} & \multirow[b]{2}{*}{$\begin{array}{l}\text { Type } \\
\text { of pump } \\
\text { and } h p\end{array}$} & \multicolumn{2}{|c|}{$\begin{array}{c}\text { Well } \\
\text { performance }\end{array}$} & \multirow[b]{2}{*}{ Use } & \multirow[b]{2}{*}{ Remarks } \\
\hline & $\begin{array}{c}\text { Feet } \\
\text { below } \\
\text { datum }\end{array}$ & Date & & & $\begin{array}{c}\text { Yield } \\
(\mathrm{gpm})\end{array}$ & $\begin{array}{l}\text { Draw- } \\
\text { down } \\
\text { (feet) }\end{array}$ & & \\
\hline
\end{tabular}

R. 3 W.

$\begin{array}{lllllllll}365 & 10.64 & 4-24-69 & 240 & \text { J, 3/4 } & - & \text { D } & \begin{array}{c}\text { Can be pumped } \\ \text { dry during } \\ \text { summer. }\end{array} \\ 342 & 10.05 & 7-14-69 & 420 & \text { S, } 3 & 40 & 12 & \text { PS } & \text { P hr, L. }\end{array}$


TABLE 8.-Records of wells in the

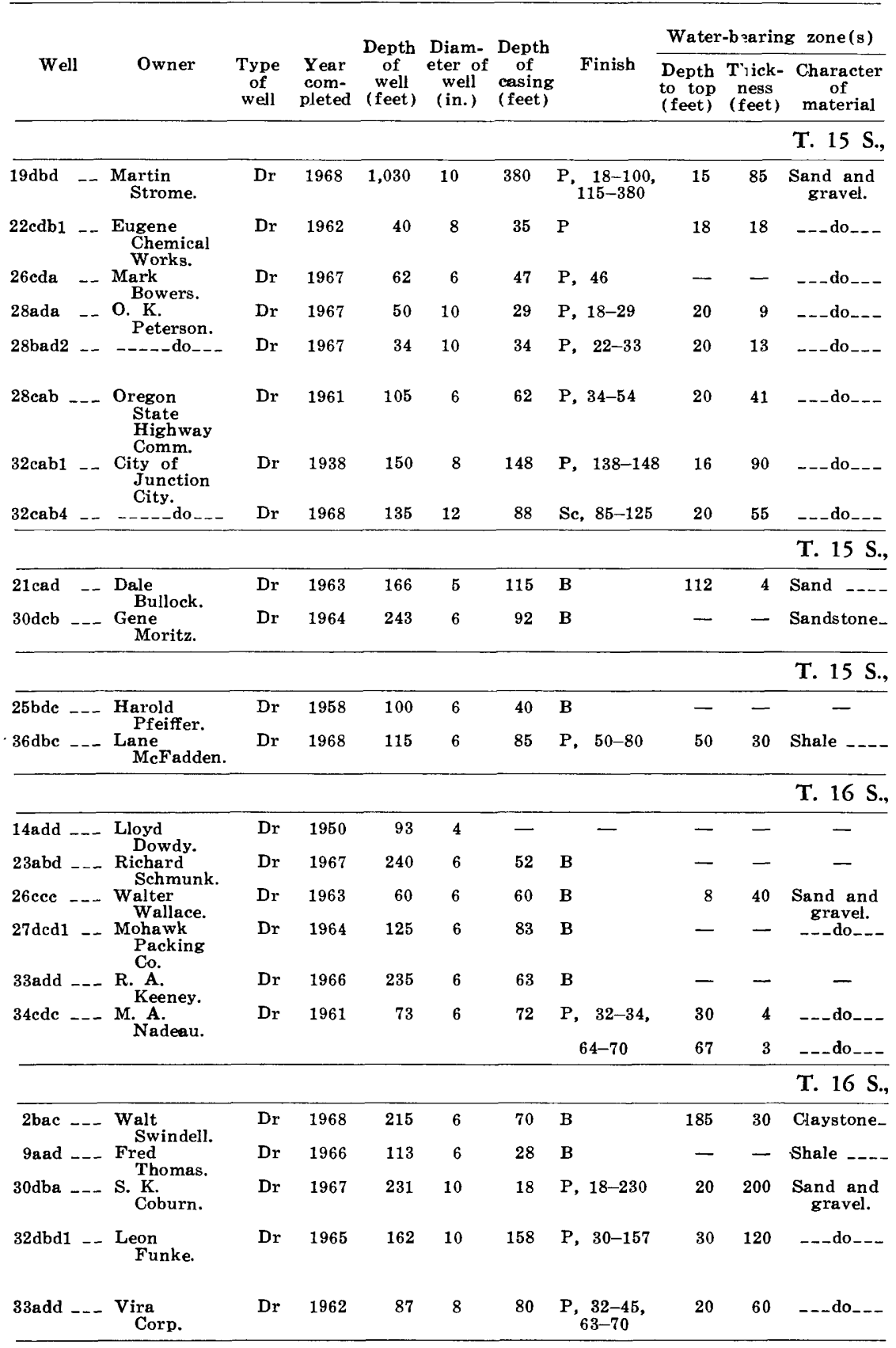


Eugene-Springfield area-Continued

\begin{tabular}{|c|c|c|c|c|c|c|c|c|}
\hline \multirow{2}{*}{$\begin{array}{l}\text { Alti- } \\
\text { tude } \\
\text { (feet) }\end{array}$} & \multicolumn{2}{|c|}{ Water level } & \multirow[b]{2}{*}{$\begin{array}{l}\text { Specific } \\
\text { conduct- } \\
\text { ance } \\
\text { of water }\end{array}$} & \multirow{2}{*}{$\begin{array}{l}\text { Type } \\
\text { of pump } \\
\text { and } h p\end{array}$} & \multicolumn{2}{|c|}{$\begin{array}{l}\text { Well } \\
\text { performance }\end{array}$} & \multirow[b]{2}{*}{ Use } & \multirow[b]{2}{*}{ Remarks } \\
\hline & $\begin{array}{l}\text { Feet } \\
\text { below } \\
\text { datum }\end{array}$ & Date & & & $\begin{array}{l}\text { Yield } \\
(\mathrm{gpm})\end{array}$ & $\begin{array}{l}\text { Draw- } \\
\text { down } \\
\text { (feet) }\end{array}$ & & \\
\hline \multicolumn{9}{|c|}{ R. 4 W. } \\
\hline 315 & 14.30 & $8-22-69$ & - & $\mathbf{N}$ & 450 & - & $\mathbf{N}$ & $\begin{array}{l}\mathrm{P} 1 / 4 \mathrm{hr} ; \text { pumps } \\
\text { excessive amount } \\
\text { of san } \mathrm{t} \text {. }\end{array}$ \\
\hline 316 & 15.57 & $10-3-68$ & - & C & - & - & 一 & \\
\hline 325 & 16 & $5-23-67$ & 210 & S, $1 / 2$ & 12 & 25 & $\mathbf{D}$ & B $1 \mathrm{hr}$. \\
\hline 314 & 13.47 & $10-4-68$ & - & $\mathbf{C}$ & 400 & 5 & Ir & P $1 \mathrm{hr}$. \\
\hline 320 & 14.14 & $7-16-69$ & - & C, 20 & 550 & 1.18 & Ir & $\begin{array}{l}\text { L; pumr tested by } \\
\text { U.S. Greological }\end{array}$ \\
\hline 342 & 10.05 & $7-14-69$ & 420 & S, 3 & 40 & 12 & PS & $\mathrm{P} 2 \mathrm{hr}$. \\
\hline 325 & 12 & 1940 & - & $T, 15$ & 160 & 23 & PS & $\begin{array}{c}\text { L; origizally drilled } \\
450 \text { feet deep. }\end{array}$ \\
\hline 325 & 14 & $8-23-68$ & - & $\mathbf{T}$ & 940 & 38 & PS & P $8 \mathrm{hr}, \mathrm{L}, \mathrm{Ca}$. \\
\hline
\end{tabular}

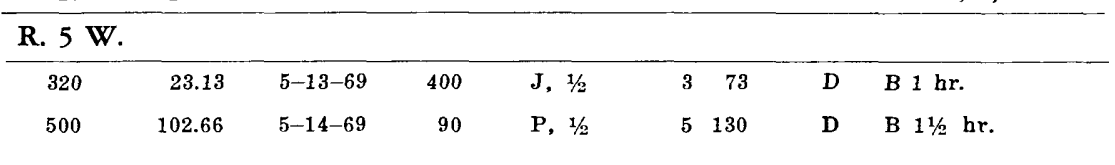

\begin{tabular}{|c|c|c|c|c|c|c|c|c|}
\hline \multicolumn{9}{|l|}{ R. $6 \mathrm{~W}$. } \\
\hline 575 & 11.07 & $5-13-69$ & - & $\mathbf{N}$ & - & - & - & \\
\hline 435 & 16 & $8-16-68$ & 420 & $\mathrm{~S}, 3 / 4$ & 10 & 20 & D & B $2 \mathrm{hr}$. \\
\hline
\end{tabular}

\begin{tabular}{ccccccclll}
\hline R. 2 W. & & & & & & & & \\
\hline 650 & Flows & $7-17-69$ & 120 & C, 1 & - & - & D & Flows 5-7 gpm. \\
700 & 36.75 & $7-18-68$ & 220 & S, 2 & 20 & D & Ca. \\
480 & 9.22 & $7-12-68$ & 140 & S, 1 & 17 & 34 & D & B 1 hr; H, fig. 7. \\
500 & 14 & $7-17-69$ & 80 & S, $21 / 2$ & 25 & 40 & In & B 11/2 hr, L. \\
560 & 30 & $8-16-66$ & 225 & S, 1 & 15 & 150 & D & B $1 \mathrm{hr}, \mathrm{Ca}$. \\
480 & 9.92 & $8-20-69$ & 140 & C, 2 & 20 & 20 & Ir & P $1 \mathrm{hr}, \mathrm{Ca} ; \mathrm{H}, \mathrm{fig}$.
\end{tabular}

R. 3 W.

\begin{tabular}{|c|c|c|c|c|c|c|c|c|}
\hline 710 & 30 & $4-25-69$ & 440 & $\mathrm{~S}, \quad 3 / 4$ & 20 & 185 & D & P $1 \mathrm{hr}$. \\
\hline 440 & 24.90 & $5-1-69$ & 410 & $J, 3 / 4$ & 18 & 30 & D & B 2 hr, Ca. \\
\hline 370 & 9.82 & $7-10-69$ & 220 & T, 20 & 300 & 7.3 & Ir & $\begin{array}{l}\text { L; pumo tested by } \\
\text { U.S. Geological } \\
\text { Survey for } 9 \mathrm{hr} \text {. }\end{array}$ \\
\hline 390 & 19.28 & $8-27-69$ & - & $T, 25$ & 235 & 14 & Ir & $\begin{array}{l}\text { Pump tested by } \\
\text { U.S. Geological } \\
\text { Surve; for } 9 \mathrm{hr} \text {; } \\
\text { H, fig. } 10 . \\
\text { B } 1 \text { hr. }\end{array}$ \\
\hline
\end{tabular}


TABLE 8.-Records of wells in the

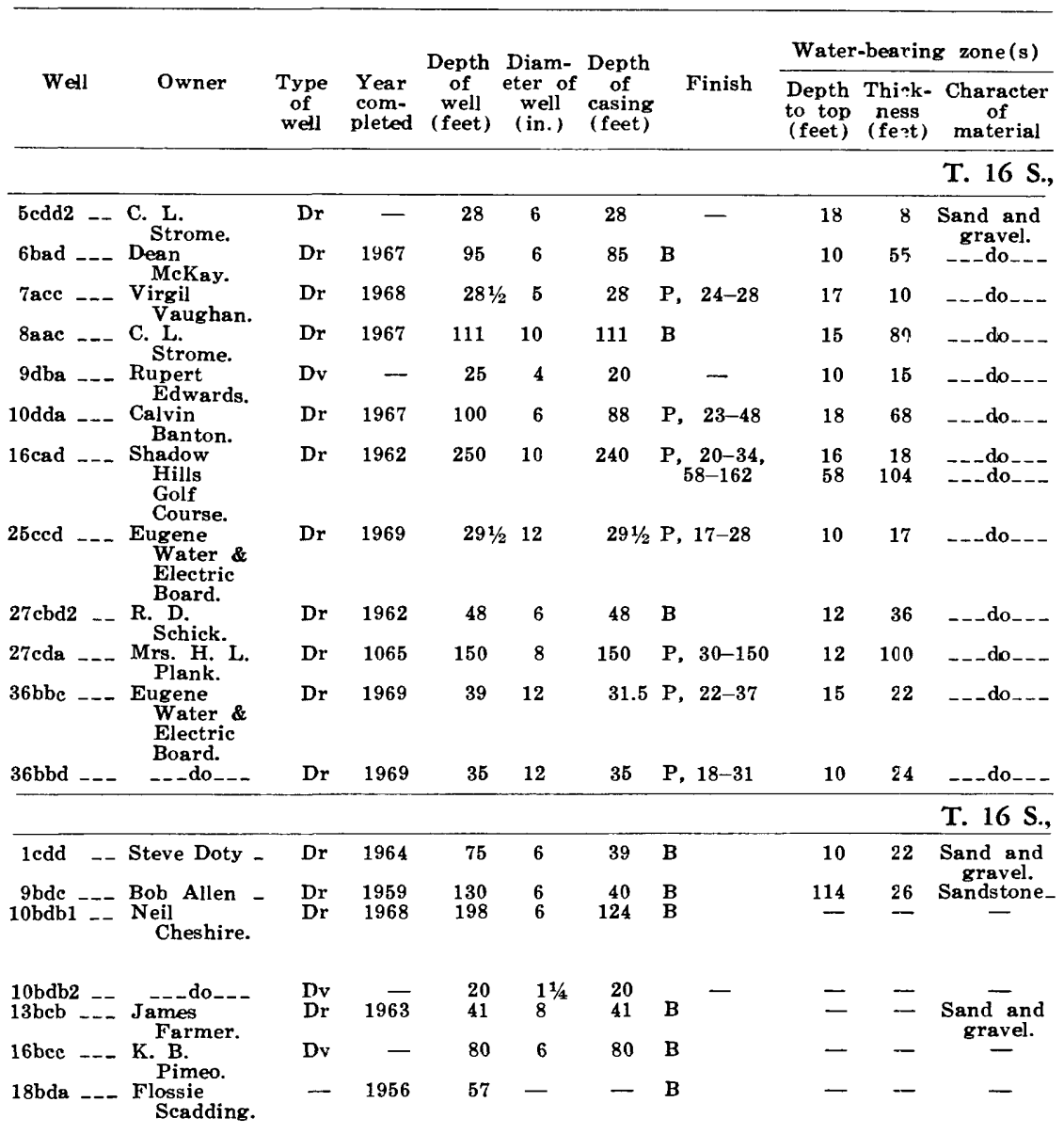

T. $16 \mathrm{~S}$.,

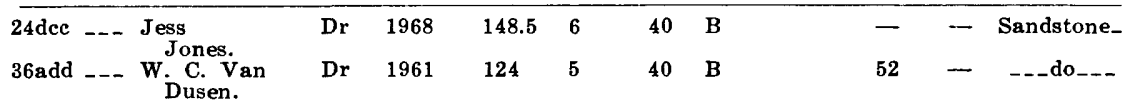

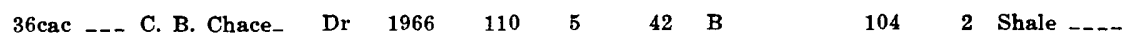

\begin{tabular}{|c|c|c|c|c|c|c|c|c|c|}
\hline & & & & & & & & & T. 17 S., \\
\hline 8cdb2 -- Vernon & Dr & 1964 & 120 & 6 & 26 & B & - & - & Claystone_- \\
\hline 9 bea -- C. L. $_{\text {Howard. }}$ & Dr & 1967 & 415 & 6 & 18 & B & - & - & - \\
\hline 17 bcb1 -- $\underset{\text { Koch. }}{\text { Ermol }}$ & Dr & 1967 & 400 & 6 & 28 & $\mathbf{B}$ & - & - & - \\
\hline 26cea1 -- $\begin{array}{c}\text { Springfield } \\
\text { Utility } \\
\text { Board. }\end{array}$ & Dr & 1966 & 70 & 12 & 52 & $P, \quad 22-52$ & 16 & 36 & $\begin{array}{l}\text { Sand and } \\
\text { gravel. }\end{array}$ \\
\hline
\end{tabular}


Eugene-Springfield area-Continued

\begin{tabular}{|c|c|c|c|c|c|c|c|c|}
\hline \multirow{2}{*}{$\begin{array}{l}\text { Alti- } \\
\text { tude } \\
\text { (feet) }\end{array}$} & \multicolumn{2}{|c|}{ Water level } & \multirow[b]{2}{*}{$\begin{array}{l}\text { Specific } \\
\text { conduct- } \\
\text { ance } \\
\text { of water }\end{array}$} & \multirow{2}{*}{$\begin{array}{c}\text { Type } \\
\text { of pump } \\
\text { and hp }\end{array}$} & \multicolumn{2}{|c|}{$\begin{array}{c}\text { Well } \\
\text { performance }\end{array}$} & \multirow[b]{2}{*}{ Use } & \multirow[b]{2}{*}{ Rernarks } \\
\hline & $\begin{array}{c}\text { Feet } \\
\text { below } \\
\text { datum }\end{array}$ & Date & & & $\begin{array}{c}\text { Yield } \\
(\mathrm{g} \mathrm{pm})\end{array}$ & $\begin{array}{c}\text { Draw- } \\
\text { down } \\
\text { (feet) }\end{array}$ & & \\
\hline \multicolumn{9}{|l|}{ R. $4 \mathrm{~W}$. } \\
\hline 330 & 12.27 & $9-17-69$ & - & $\mathbf{N}$ & - & - & $\mathbf{N}$ & H, fig. 9. \\
\hline 320 & 7.08 & $9-18-69$ & - & S, 1 & 150 & 10 & D & B $1 \mathrm{hr}, \mathrm{L}$. \\
\hline 332 & 7.09 & $9-23-68$ & 220 & C, $11 / 2$ & 35 & 5 & Ir & P 1 hr; H, fig. 9. \\
\hline 330 & 12.26 & $9-17-68$ & - & $\mathrm{T}, 40$ & 600 & 35 & Ir & P $4 \mathrm{hr}$. \\
\hline 335 & 13.49 & $9-18-68$ & - & $\mathbf{H}$ & - & - & D & H, fig. 9 . \\
\hline 340 & 11.55 & $9-18-68$ & - & $\mathbf{N}$ & 一 & 一 & $\mathbf{N}$ & H, fig. 8 . \\
\hline 340 & 5 & 1962 & - & $T, 20$ & 478 & 95 & Ir & P $120 \mathrm{hr}$, L. \\
\hline 360 & 3 & $7-18-69$ & - & $\mathbf{N}$ & 1,210 & - & $\mathbf{T}$ & $\mathrm{P} 481 / 2 \mathrm{hr}, \mathrm{Ca}$. \\
\hline 358 & 4 & $5-1-62$ & 300 & J, 1 & 20 & 15 & D & P $1 \mathrm{hr}, \mathrm{C}$. \\
\hline 358 & 6 & $4-21-65$ & - & $T, 25$ & 325 & 34 & Ir & P $8 \mathrm{hr}$. \\
\hline 370 & 9 & $7-22-69$ & - & $\mathbf{N}$ & 1,230 & - & $\mathbf{T}$ & P $48 \mathrm{hr}, \mathrm{Ca}$ \\
\hline 365 & 5 & $7-12-69$ & - & $\mathbf{N}$ & 1,200 & - & $\mathbf{T}$ & P $50 \mathrm{hr}$. Ca. \\
\hline
\end{tabular}

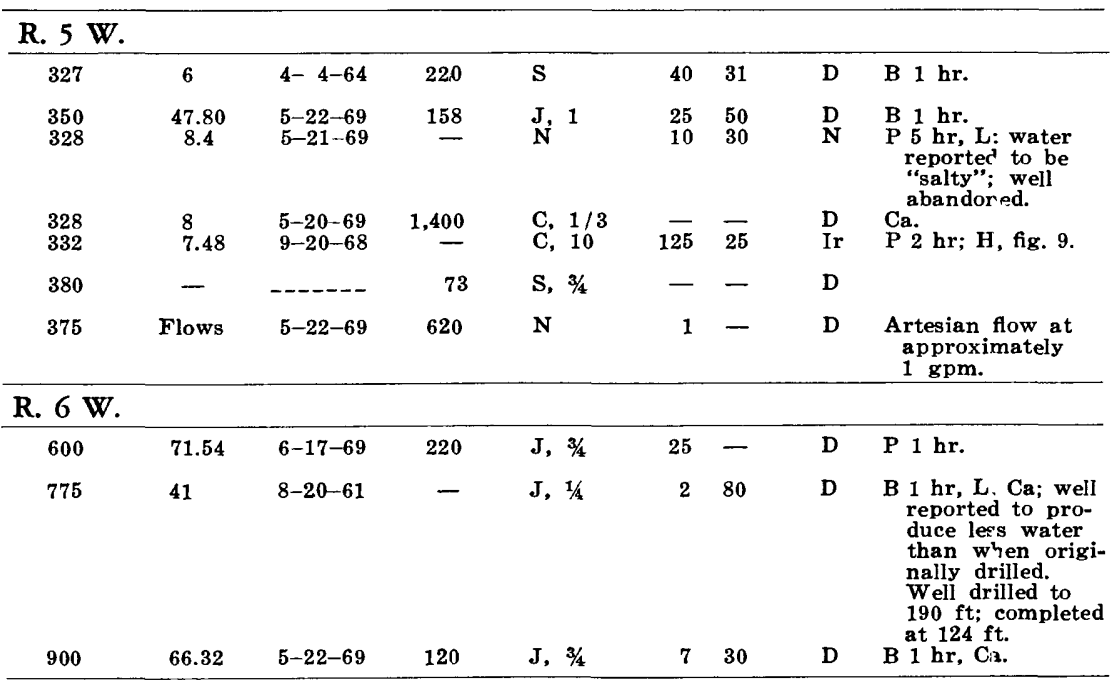

\begin{tabular}{|c|c|c|c|c|c|c|c|c|}
\hline R. $2 \mathrm{~W}$. & & & & & & & & \\
\hline 590 & 10 & $10-26-64$ & 165 & $\mathrm{~J}, 3 / 4$ & 22 & 70 & D & B $2 \mathrm{hr}$. \\
\hline 575 & 22.04 & $7-23-68$ & - & $\mathbf{N}$ & 1 & 355 & $\mathbf{N}$ & B 2 hr, L: inade- \\
\hline 495 & 41.63 & $7-23-68$ & 110 & $\mathbf{J}$ & 4 & 300 & D & $\begin{array}{l}\text { B } 1 \text { hr; adequate } \\
\text { water s'lpply for } \\
\text { home. }\end{array}$ \\
\hline 510 & 10.55 & $9-10-69$ & - & $T, 60$ & 900 & 11 & PS & p $18 \mathrm{hr}$ \\
\hline
\end{tabular}


TABLE 8.-Records of wells in the

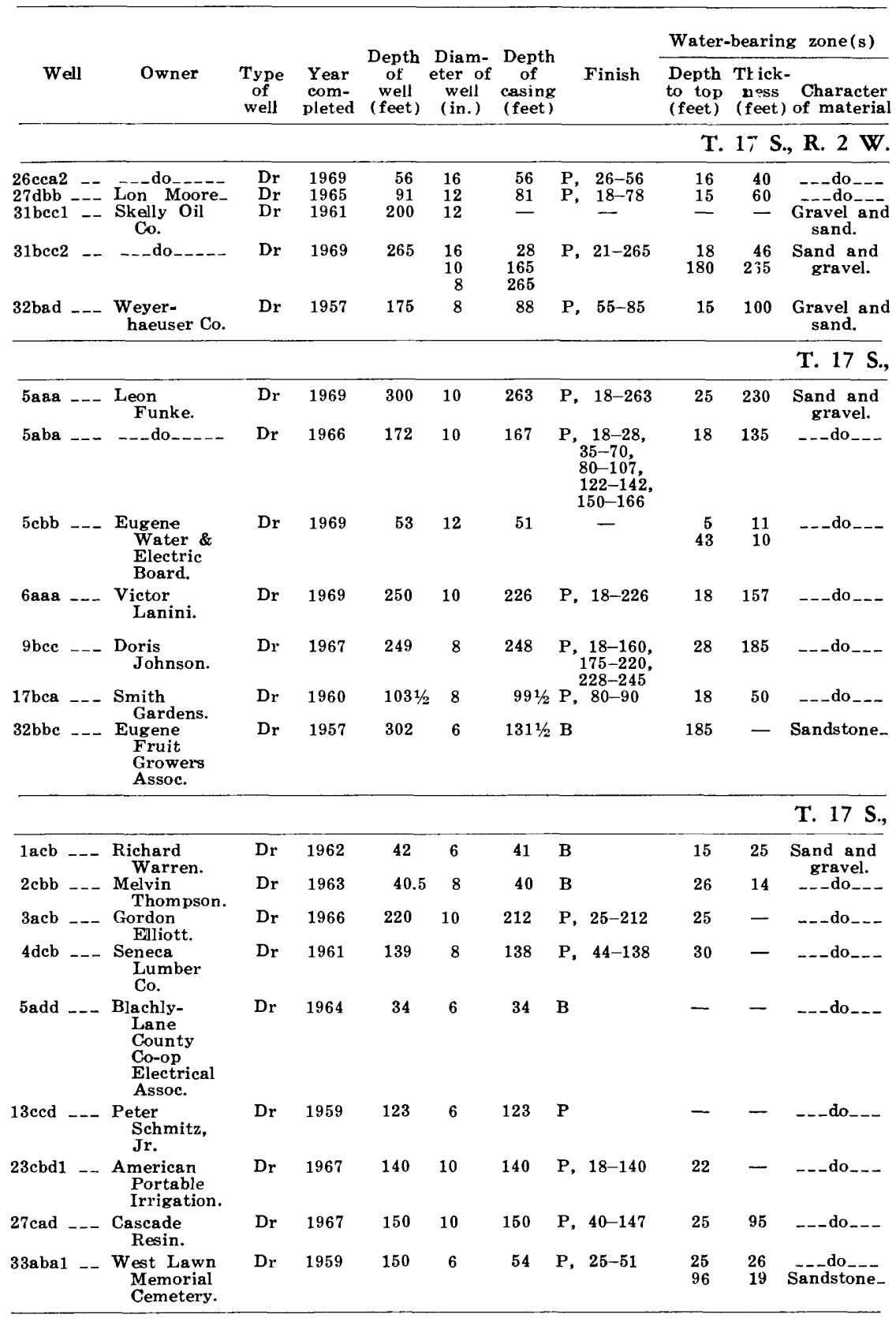


Eugene-Springfield area-Continued

\begin{tabular}{|c|c|c|c|c|c|c|c|c|}
\hline \multirow{2}{*}{$\begin{array}{l}\text { Alti- } \\
\text { tude } \\
\text { (feet) }\end{array}$} & \multicolumn{2}{|c|}{ Water level } & \multirow[b]{2}{*}{$\begin{array}{l}\text { Specific } \\
\text { conduct- } \\
\text { ance } \\
\text { of water }\end{array}$} & \multirow{2}{*}{$\begin{array}{c}\text { Type } \\
\text { of pump } \\
\text { and hp }\end{array}$} & \multicolumn{2}{|c|}{$\begin{array}{c}\text { Well } \\
\text { performance }\end{array}$} & \multirow[b]{2}{*}{ Use } & \multirow[b]{2}{*}{ Rernarks } \\
\hline & $\begin{array}{c}\text { Feet } \\
\text { below } \\
\text { datum }\end{array}$ & Date & & & $\begin{array}{c}\text { Yield } \\
(\mathrm{gpm})\end{array}$ & $\begin{array}{c}\text { Draw- } \\
\text { down } \\
\text { (feet) }\end{array}$ & & \\
\hline \multicolumn{9}{|c|}{-Continued } \\
\hline $\begin{array}{l}510 \\
502 \\
472\end{array}$ & $\begin{array}{l}10.90 \\
9.42 \\
20\end{array}$ & $\begin{array}{l}9-10-69 \\
9-10-67 \\
8-29-69\end{array}$ & $\bar{z}$ & $\begin{array}{l}\mathrm{T}, 100 \\
\mathbf{N}, 15\end{array}$ & $\begin{array}{r}1,150 \\
400 \\
-\end{array}$ & $\begin{array}{r}9 \\
8 \\
-\end{array}$ & $\begin{array}{l}\text { PS } \\
\text { N } \\
\text { In }\end{array}$ & $\begin{array}{l}\text { P } 24 \text { hr, L, Ca. } \\
\text { P } 6 \text { hr; F, fig. } 8 . \\
\text { Ca. }\end{array}$ \\
\hline 472 & 12 & $4-11-69$ & - & $\mathrm{T}, 25$ & 300 & 58 & In & P $4 \mathrm{hr}$. \\
\hline 485 & 7.32 & $8-14-69$ & - & $\mathbf{N}$ & 175 & 35 & $\mathbf{N}$ & P 2 hr; Fr, fig. 10 . \\
\hline
\end{tabular}

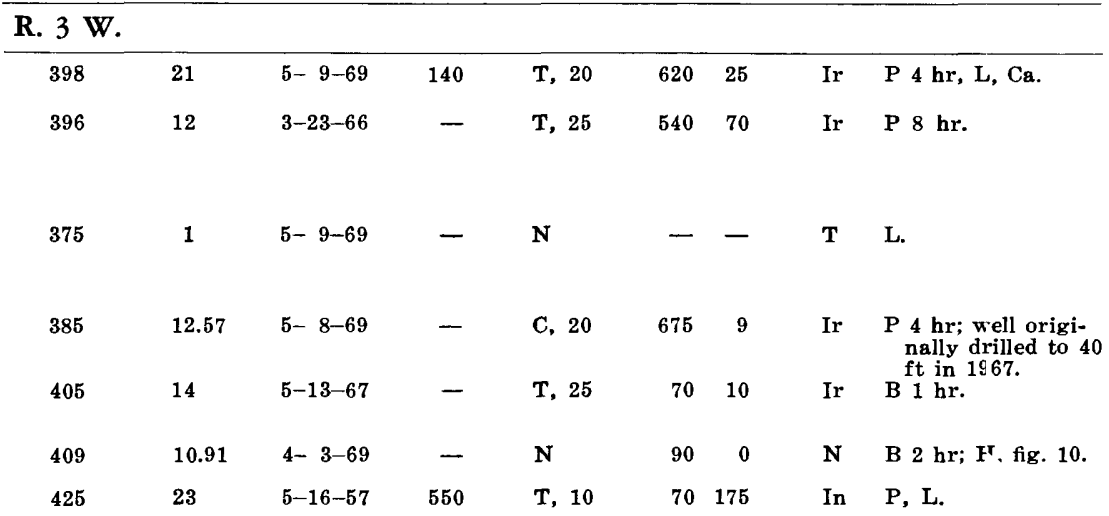

R. 4 W.

$\begin{array}{lcrllrlll}377 & 10 & 10-27-62 & - & \text { S, 3/4 } & 40 & 10 & \text { D } & \text { B } 1 \mathrm{hr} . \\ 375 & 5.70 & 1-22-69 & - & \text { C, } 15 & 390 & 12 & \text { Ir } & \text { B. } \\ 373 & 3 & 4-7-66 & - & \text { T, } 60 & 556 & 140 & \text { Ir } & \text { P 1 1/2 hr, L. } \\ 370 & 13 & 7-11-61 & - & \text { T } & - & - & \text { In } & \\ 365 & 1.06 & 4-10-69 & 200 & \text { S } & 20 & 9 & \text { D } & \text { B } 1 \text { hr. }\end{array}$

$\begin{array}{rlrrrrrrr}400 & 18 & 11-30-59 & 264 & \text { J, 3 } & 25 & 10 & \text { In } & \text { P } 11 / 2 \mathrm{hr}, \mathrm{L}, \mathrm{Ca} . \\ 395 & 10 & 5-3-67 & - & \text { T, } 10 & 380 & 70 & \text { In } & \text { P } 1 \mathrm{hr} . \\ 395 & 17 & 9-5-68 & - & \text { T } & 500 & 93 & \text { N } & \text { P } 4 \mathrm{hr} . \\ 390 & 15.25 & 4-14-69 & - & \text { T, } 15 & 60 & 20 & \text { Ir } & \text { P } 1 \mathrm{hr}, \mathrm{L} ; \mathrm{H}, \text { fig. }\end{array}$


TABLE 8.-Records of wells in the

\begin{tabular}{|c|c|c|c|c|c|c|c|c|c|c|}
\hline \multirow[b]{2}{*}{ Well } & \multirow[b]{2}{*}{ Owner } & \multirow[b]{2}{*}{$\begin{array}{l}\text { Type } \\
\text { of } \\
\text { well }\end{array}$} & \multirow[b]{2}{*}{$\begin{array}{l}\text { Year } \\
\text { com- } \\
\text { pleted }\end{array}$} & \multirow{2}{*}{$\begin{array}{c}\text { Depth } \\
\text { of } \\
\text { well } \\
\text { (feet) }\end{array}$} & \multirow{2}{*}{$\begin{array}{l}\text { Diam- } \\
\text { eter of } \\
\text { well } \\
\text { (in.) }\end{array}$} & \multirow{2}{*}{$\begin{array}{l}\text { Depth } \\
\text { of } \\
\text { casing } \\
\text { ( feet) }\end{array}$} & \multirow[b]{2}{*}{ Finish } & \multicolumn{3}{|c|}{ Water-hearing zone (s) } \\
\hline & & & & & & & & $\begin{array}{l}\text { Depth } \\
\text { to top } \\
\text { (feet) }\end{array}$ & $\begin{array}{c}\text { Thick- } \\
\text { ness } \\
\text { (feet) }\end{array}$ & $\begin{array}{c}\text { Character } \\
\text { of material }\end{array}$ \\
\hline & & & & & & & & & & T. 17 S., \\
\hline $2 \mathbf{a b b}$ & $\begin{array}{c}\text { Kenneth } \\
\text { Drew. }\end{array}$ & Dr & 1965 & 90 & 6 & 61 & $P, \quad 18-59$ & 15 & 46 & $\begin{array}{l}\text { Sand and } \\
\text { gravel. }\end{array}$ \\
\hline 3aad --- & $\begin{array}{l}\text { Decker's } \\
\text { Nursery. }\end{array}$ & Dr & 1968 & 160 & 8 & 114 & P, 30-114 & 30 & 90 & $\begin{array}{l}\text { Sand, } \\
\text { gravel, } \\
\text { and clay. }\end{array}$ \\
\hline $5 \mathrm{cbb}--$ & Clyne Funk & Dr & 1968 & 140 & 6 & 53 & B & 48 & 8 & Gravel -- - \\
\hline 13bdd --- & $\begin{array}{l}\text { Ebert } \\
\text { Griesel. }\end{array}$ & $\mathrm{Dr}$ & 1960 & 96.5 & 8 & 96.5 & P, 71-96 & 57 & 39 & $\begin{array}{l}\text { Sand, } \\
\text { gravel, } \\
\text { and clay. }\end{array}$ \\
\hline 31bca 1 -- & $\begin{array}{l}\text { City of } \\
\text { Veneta. }\end{array}$ & Dr & 1967 & 124 & $\begin{array}{l}12 \\
10\end{array}$ & $\begin{array}{r}76 \\
124\end{array}$ & S, 79-119 & 60 & 60 & $\begin{array}{c}\text { Sand and } \\
\text { gravel. }\end{array}$ \\
\hline $36 \mathrm{adb}---$ & $\begin{array}{c}\text { Bonneville } \\
\text { Power } \\
\text { Adm. }\end{array}$ & Dr & 1966 & 200 & 6 & 187 & S, 187-197 & - & - & Shale _--- \\
\hline
\end{tabular}

T. 17 S.,

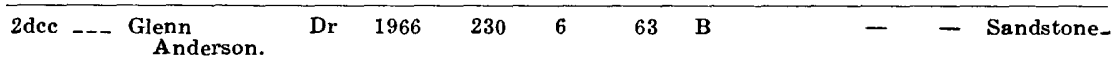

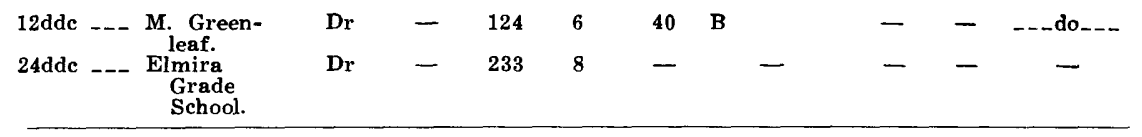

T. $18 \mathrm{~S}$.,

\begin{tabular}{|c|c|c|c|c|c|c|c|c|c|}
\hline 11aaa 1 & $\begin{array}{l}\text { Norman } \\
\text { Hutchin- } \\
\text { son. }\end{array}$ & Dr & 1965 & 145 & 6 & 63 & B & - & - Sandstone \\
\hline
\end{tabular}

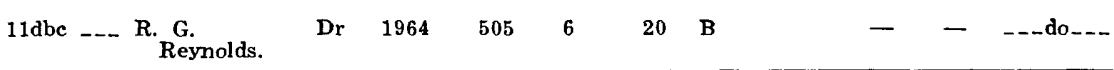

\begin{tabular}{|c|c|c|c|c|c|c|c|c|c|}
\hline & & & & & & & & & T. $18 \mathrm{~S}$. \\
\hline I2ddd $---\begin{array}{c}\text { Harold } \\
\text { Estep. }\end{array}$ & Dr & 1967 & 65 & 6 & 65 & $P, \quad 18-48$ & 18 & 47 & $\begin{array}{c}\text { Sand and } \\
\text { gravel. }\end{array}$ \\
\hline
\end{tabular}

T. 18 S.,

\begin{tabular}{|c|c|c|c|c|c|c|c|c|c|c|c|}
\hline $\begin{array}{l}3 \text { cad } \\
7 \text { ced }\end{array}$ & $\begin{array}{l}\text { Nils Hult } \\
-- \text { Royal } \\
\text { Sanders. }\end{array}$ & - & $\begin{array}{l}\mathrm{Dr} \\
\mathrm{Dr}\end{array}$ & $\begin{array}{l}1957 \\
1964\end{array}$ & $\begin{array}{l}241 \\
\mathbf{2 5 0}\end{array}$ & $\begin{array}{l}6 \\
6\end{array}$ & $\overline{24}$ & $\underset{\mathbf{B}}{\mathbf{B}}$ & $\begin{array}{r}238 \\
18\end{array}$ & $\begin{array}{r}3 \\
232\end{array}$ & $\begin{array}{l}\text { Sandstone.. } \\
\text { Claystone_- }\end{array}$ \\
\hline $14 \mathrm{acb}$ & $\begin{array}{c}\text { Eranders. } \\
\text { Muster. } \\
\text { Muster. }\end{array}$ & & $\mathrm{Dr}$ & 1959 & 502 & 5 & 334 & B & 330 & 172 & Sandstone \\
\hline
\end{tabular}

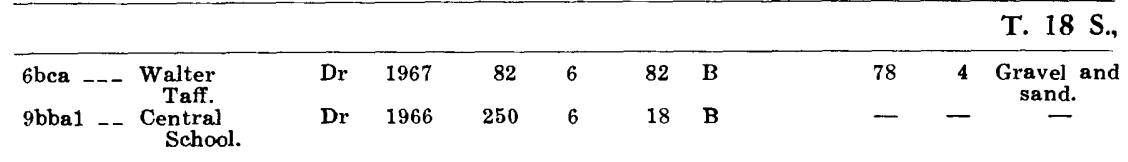




\section{Eugene-Springfield area-Continued}

\begin{tabular}{|c|c|c|c|c|c|c|c|c|}
\hline \multirow{2}{*}{$\begin{array}{l}\text { Alti- } \\
\text { tude } \\
\text { (feet) }\end{array}$} & \multicolumn{2}{|c|}{ Water level } & \multirow[b]{2}{*}{$\begin{array}{l}\text { Specific } \\
\text { conduct- } \\
\text { ance } \\
\text { of water }\end{array}$} & \multirow{2}{*}{$\begin{array}{l}\text { Type } \\
\text { of pump } \\
\text { and hp }\end{array}$} & \multicolumn{2}{|c|}{$\begin{array}{c}\text { Well } \\
\text { performance }\end{array}$} & \multirow[b]{2}{*}{ Use } & \multirow[b]{2}{*}{ Remarks } \\
\hline & $\begin{array}{l}\text { Feet } \\
\text { below } \\
\text { datum }\end{array}$ & Date & & & $\begin{array}{c}\text { Yiedd } \\
(\text { gpm })\end{array}$ & $\begin{array}{l}\text { Draw- } \\
\text { down } \\
\text { (feet) }\end{array}$ & & \\
\hline
\end{tabular}

R. 5 W.

\begin{tabular}{|c|c|c|c|c|c|c|c|c|}
\hline 378 & 8 & $8-29-65$ & 50 & S. 1 & 80 & $\mathbf{5}$ & D & B $1 \mathrm{hr}$. \\
\hline 360 & 21.52 & $9-23-69$ & 52 & $\mathbf{S}$ & 110 & 85 & Ir & $\begin{array}{l}\text { P } 1 \mathrm{hr} \text {; well origi- } \\
\text { nally } 110 \mathrm{ft} \text {; } \\
\text { deepened to } 160 \\
\text { ft. }\end{array}$ \\
\hline 400 & 8.73 & $5-20-69$ & 205 & S, 1 & $41 / 2$ & 125 & $\mathbf{r}$ & P $1 \mathrm{hr}$ \\
\hline 390 & 15.20 & $6-18-69$ & 85 & C, 2 & 120 & 4 & Ir & P $1 \mathrm{hr} ; \mathrm{H}$, fig. 10 . \\
\hline 410 & 48.15 & $5-14-69$ & 155 & T, 15 & 190 & 58 & PS & P $24 \mathrm{hr}, \mathrm{L}$. \\
\hline 398 & 8.5 & $3-25-66$ & 320 & $S, 1 \frac{1}{2}$ & 25 & 82 & D & $\mathrm{P} 4 \mathrm{hr}, \mathrm{Ca}$. \\
\hline
\end{tabular}

\begin{tabular}{|c|c|c|c|c|c|c|c|c|}
\hline \multicolumn{9}{|c|}{ R. $6 \mathrm{~W}$. } \\
\hline 675 & 39.70 & $5-28 \quad 69$ & 280 & S, $1 / 3$ & 2 & 150 & D & $\begin{array}{l}\text { B } 1 \mathrm{hr} \text {; at this } \\
\text { location two } \\
\text { springs are used } \\
\text { for stock and } \\
\text { garden. Judi- } \\
\text { cious use of all } \\
\text { water arailable } \\
\text { makes th is well } \\
\text { adequate for } \\
\text { most hol'sehold } \\
\text { needs. }\end{array}$ \\
\hline 450 & - & - & 979 & J, 1 & - & - & D & Ca. \\
\hline 390 & 29.62 & $5-14-69$ & 1,249 & S, 2 & - & - & PS & Ca. \\
\hline
\end{tabular}

\begin{tabular}{cccccccccc}
\hline R. 2 W. & & & & & & \\
\hline 1,420 & 14.43 & $7-31-68$ & 105 & S, $1 / 2$ & 5 & 140 & Ir & $\begin{array}{c}\text { B 1 hr; used to } \\
\text { irrigate lawn and } \\
\text { garden; a 126-ft } \\
\text { well is used for } \\
\text { the hous 3. }\end{array}$ \\
870 & 240 & $9-2-64$ & 750 & S, $11 / 2$ & 6 & 260 & D & B 1 hr, Ca.
\end{tabular}

R. 3 W.

$\begin{array}{lllllllllll}469 & 13.26 & 3-28-69 & - & \mathrm{S}, 2 & 40 & 30 & \text { Ir } & \text { B } 1 & \text { hr. }\end{array}$

R. 4 W.

\begin{tabular}{rrrllllll}
560 & 158 & $12-7-57$ & 672 & & -38 & 57 & D & P $63 / 4 \mathrm{hr}, \mathrm{I}, \mathrm{Ca}$. \\
560 & 20 & $8-18-64$ & 293 & S, 3/4 & 10 & 200 & D & B 1 hr, Ca \\
810 & 180 & $10-9-59$ & 885 & S, 1 & $20+50$ & D & B 2 hr, L, Ca. \\
\hline
\end{tabular}

R. 5 W.

$\begin{array}{rrrrrrrrr}420 & 54 & 6-28-67 & - & \text { J, 3/4 } & 15 & 15 & \text { D } & \text { B 1 hr. } \\ 400 & 19 & 5-31-66 & - & \text { J, 1/2 } & 5 & 225 & \text { PS } \begin{array}{l}\text { B 1 hr, L; school } \\ \text { has anotter 250- } \\ \text { ft, 6-in. diam } \\ \text { well which pro- } \\ \text { duces 2 gm. }\end{array}\end{array}$


TABLE 8.-Records of wells in the

\begin{tabular}{|c|c|c|c|c|c|c|c|c|c|c|}
\hline \multirow[b]{2}{*}{ Well } & \multirow[b]{2}{*}{ Owner } & \multirow[b]{2}{*}{$\begin{array}{l}\text { Type } \\
\text { of } \\
\text { well }\end{array}$} & \multirow[b]{2}{*}{$\begin{array}{l}\text { Year } \\
\text { com- } \\
\text { pleted }\end{array}$} & \multirow{2}{*}{$\begin{array}{c}\text { Depth } \\
\text { of } \\
\text { well } \\
\text { (feet) }\end{array}$} & \multirow{2}{*}{$\begin{array}{l}\text { Diam- } \\
\text { eter of } \\
\text { well } \\
\text { (in.) }\end{array}$} & \multirow{2}{*}{$\begin{array}{l}\text { Depth } \\
\text { of } \\
\text { casing } \\
\text { (feet) }\end{array}$} & \multirow[b]{2}{*}{ Finish } & \multicolumn{3}{|c|}{ Water-b ?aring zone $(s)$} \\
\hline & & & & & & & & $\begin{array}{l}\text { Depth } \\
\text { to top } \\
\text { (feet) }\end{array}$ & $\begin{array}{c}\text { Thick- } \\
\text { ness } \\
\text { (feet) }\end{array}$ & $\begin{array}{c}\text { Character } \\
\text { of } \\
\text { material }\end{array}$ \\
\hline & & & & & & & & & & T. 18 S., \\
\hline $1 \mathrm{ccb}---$ & $\begin{array}{l}\text { Curtis } \\
\text { Sizemore. }\end{array}$ & $\mathrm{Dr}$ & 1968 & 84 & 6 & 41 & B & 33 & 51 & $\begin{array}{l}\text { Rock, } \\
\text { sedi- }\end{array}$ \\
\hline $1 \mathrm{ddd}$ & $\underset{\text { White. }}{\text { Clark }}$ & Dr & 1964 & 177 & 6 & 143 & B & - & - & \\
\hline
\end{tabular}

\section{REFERENCES}

Bartholomew, W. S., and DeBow, Robert, 1967, Ground-water levels, 1966 : Oregon State Engineer Ground Water Rept. 12, 122 p.

Columbia Basin Inter-Agency Committee, 1963, River mile index: Portland, Oreg., Willamette River Hydrology Subcommittee Rept., 57 p.

Fenneman, N. M., 1931, Physiography of the western United States: New York, MeGraw-Hill Book Co., 534 p.

Ferris, J. G., Knowles, D. B., Brown, R. H., and Stallman, R. W., 1962, Theory of aquifer tests: U.S. Geol. Survey Water-Supply Paper 1536-E, p. 69-174.

Frank, F. J., and Johnson, N. A., 1970, Selected ground-water data in the Eugene-Springfield area, southern Willamette Valley, Oreron: Oregon State Engineer Ground Water Rept. 14, 70 p.

Goldblatt, E. L., Van Denburgh, A. S., and Marsland, R. A., 1963, The unusual and widespread occurrence of arsenic in well waters of Lane County, Oregon: Eugene, Oreg., Lane County Dept. Public Health, 24 p.

Johnsgard, G. A., 1963, Temperature and the water balance for Oregon weather stations: Corvallis, Oregon State Univ. Agr. Expt. Sta. Spec. Rept. $150,127 \mathrm{p}$.

Johnson, A. I., 1967, Specific yield-Compilation of specific yields for various materials: U.S. Geol. Survey Water-Supply Paper 1662-D, p. D1-D74.

Johnson, Edward E., Inc., 1966, Ground water and wells: St. Paul, Minn., $440 \mathrm{p}$.

Peck, D. L., Griggs, A. B., Schlicker, H. G., Wells, F. G., and Dole, H. M., 
Eugene-Springfield area-Continued

\begin{tabular}{|c|c|c|c|c|c|c|c|c|}
\hline \multirow{2}{*}{$\begin{array}{c}\text { Alti- } \\
\text { tude } \\
\text { (feet) }\end{array}$} & \multicolumn{2}{|c|}{ Water level } & \multirow[b]{2}{*}{$\begin{array}{l}\text { Specific- } \\
\text { conduct- } \\
\text { ance } \\
\text { of water }\end{array}$} & \multirow{2}{*}{$\begin{array}{l}\text { Type } \\
\text { of pump } \\
\text { and } h p\end{array}$} & \multicolumn{2}{|c|}{$\begin{array}{c}\text { Well } \\
\text { performance }\end{array}$} & \multirow[b]{2}{*}{ Use } & \multirow[b]{2}{*}{ Remarks } \\
\hline & $\begin{array}{c}\text { Feet } \\
\text { below } \\
\text { datum }\end{array}$ & Date & & & $\begin{array}{l}\text { Yield } \\
(\mathrm{gpm})\end{array}$ & $\begin{array}{c}\text { Draw- } \\
\text { down } \\
\text { (feet) }\end{array}$ & & \\
\hline \multicolumn{9}{|c|}{ R. 6 W. } \\
\hline 525 & 14.13 & $5-12-69$ & 220 & $\mathrm{~J}, 1$ & 11 & 75 & $\mathrm{D}$ & $\begin{array}{l}\text { B } 1 \mathrm{hr} \text {; artesian } \\
\text { flow when drilled. }\end{array}$ \\
\hline 450 & 80 & $3-24-64$ & 800 & $\mathrm{~J}, 1$ & 15 & 72 & $\mathbf{D}$ & $\begin{array}{l}\text { B } 1 \mathrm{hr} \text {; drilled to } \\
190 \mathrm{ft} \text {, finished } \\
\text { at } 177 \mathrm{ft} \text {. }\end{array}$ \\
\hline
\end{tabular}

1964, Geology of the central and northern parts of the Western Cascade Range in Oregon: U.S. Geol. Survey Prof. Paper 449, 56 p.

Piper, A. M., 1942, Ground-water resources of the Willamette Valley, Oregon: U.S. Geol.' Survey Water-Supply Paper 890, 194 p.

Sceva, J. E., and DeBow, Robert, 1965, Ground-water levels, 1964: Oregon State Engineer Ground Water Rept. 5, $109 \mathrm{p}$.

- 1966, Ground-water levels, 1965: Oregon State Engineer Ground Water Rept. 9, 111 p.

Theis, C. V., Brown, R. H., and Meyer, R. R., 1963, Estimating th transmissibility of aquifers from the specific capacity in wells, in Bentall, Ray, compiler, Methods of determining permeability, transmissibility, and drawdown: U.S. Geol. Survey Water-Supply Paper 1536-I, p. 331341.

U.S. Geological Survey, 1962-69, Water-resources data from Oregon, 196168, Part 1: Portland, Oreg., U.S. Geol. Survey open-file repts., 313 p., 352 p, 372 p., 397 p., 359 p., 355 p., 364 p., 372 p.

1963, Compilation of records of surface waters of the United States, October 1950 to September 1960-Part 14, Pacific slope basins in Oregon and lower Columbia River basin: U.S. Geol. Survey Water-Supply Paper 1738, 327 p. [1964]

U.S. Public Health Service, 1962, Drinking water standards, 1962: Public Health Service Pub. 956, 61 p.

Vokes, H. E., Snavely, P. D., Jr., and Myers, D. A., 1951, Geology of the southern and southwestern border area of the Willamette Valley, Oregon: U.S. Geol. Survey Oil and Gas Inv. Map OM-110, scale 1:62,500. 

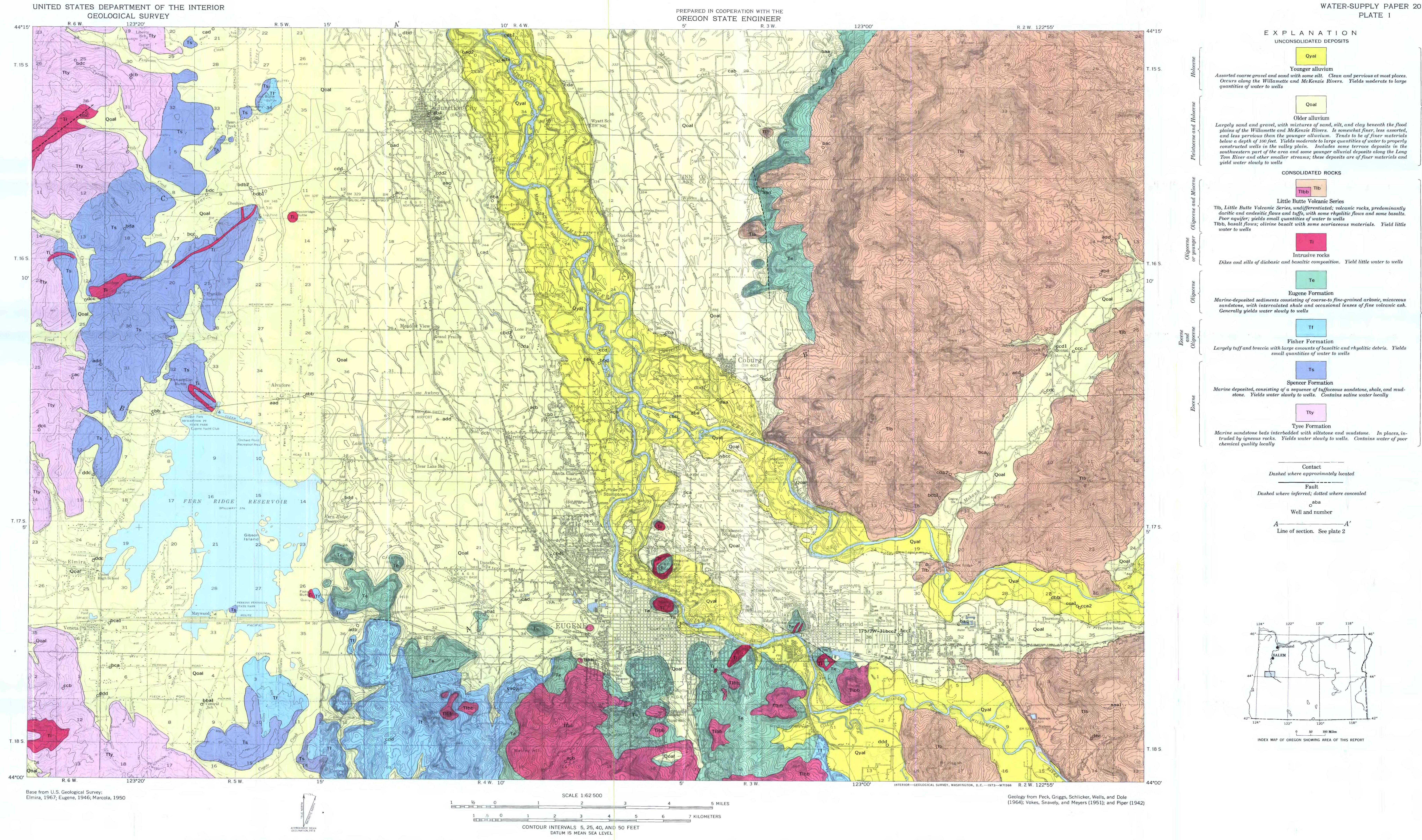

GEOLOGIC MAP OF THE EUGENE-SPRINGFIELD AREA, SOUTHERN WILLAMETTE VALLEY, OREGON

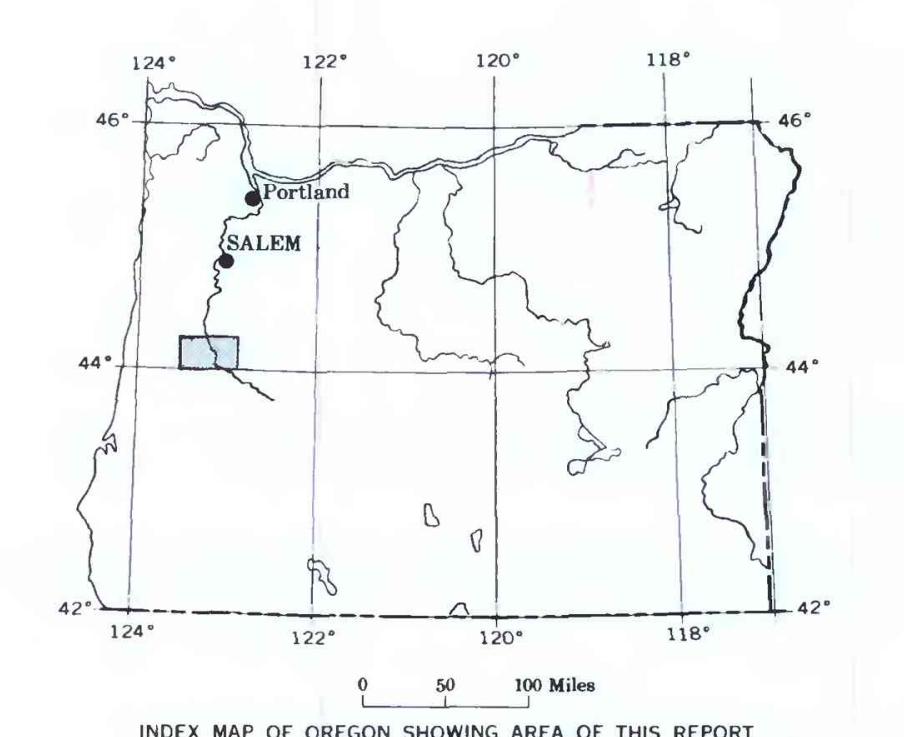



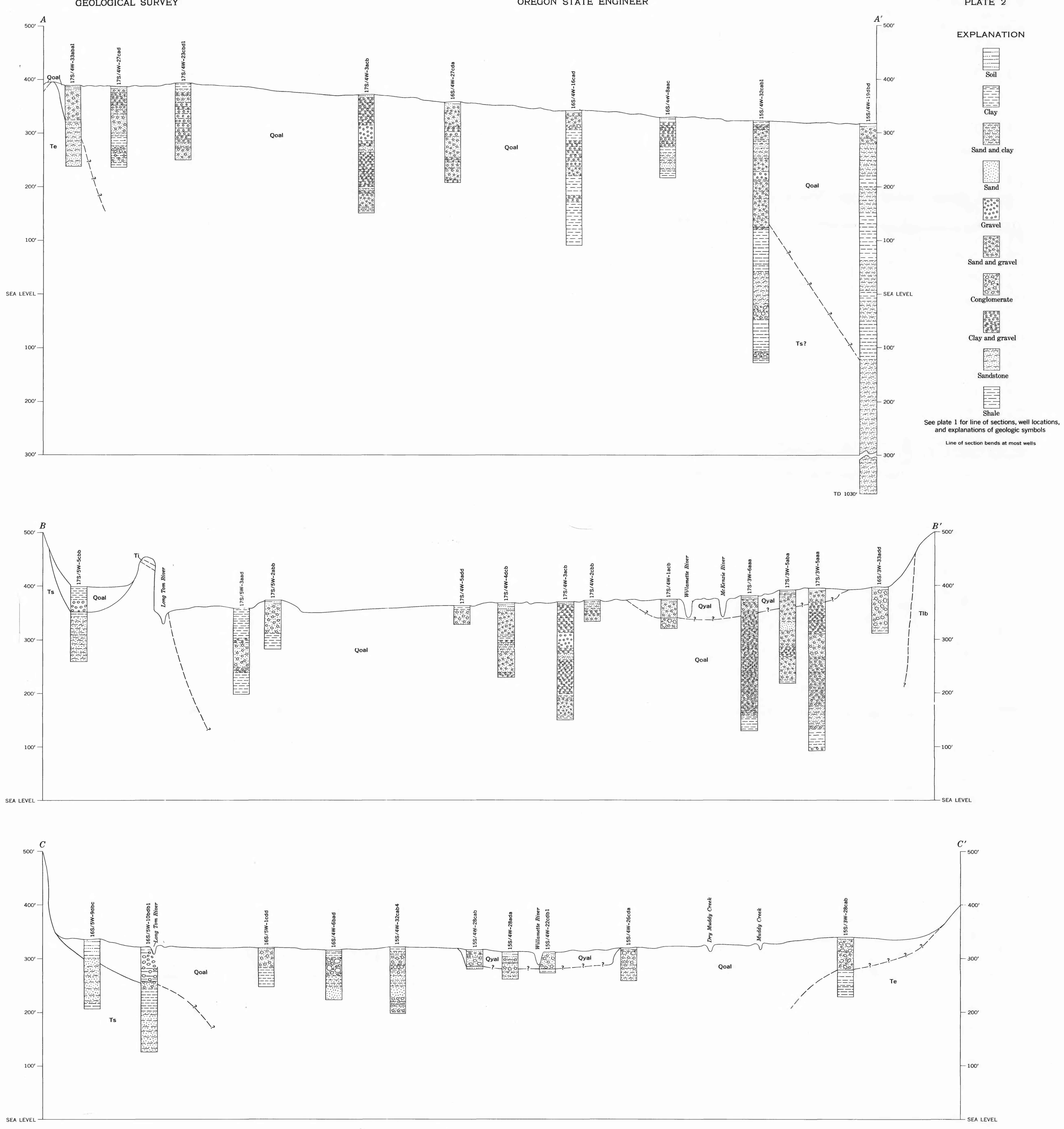


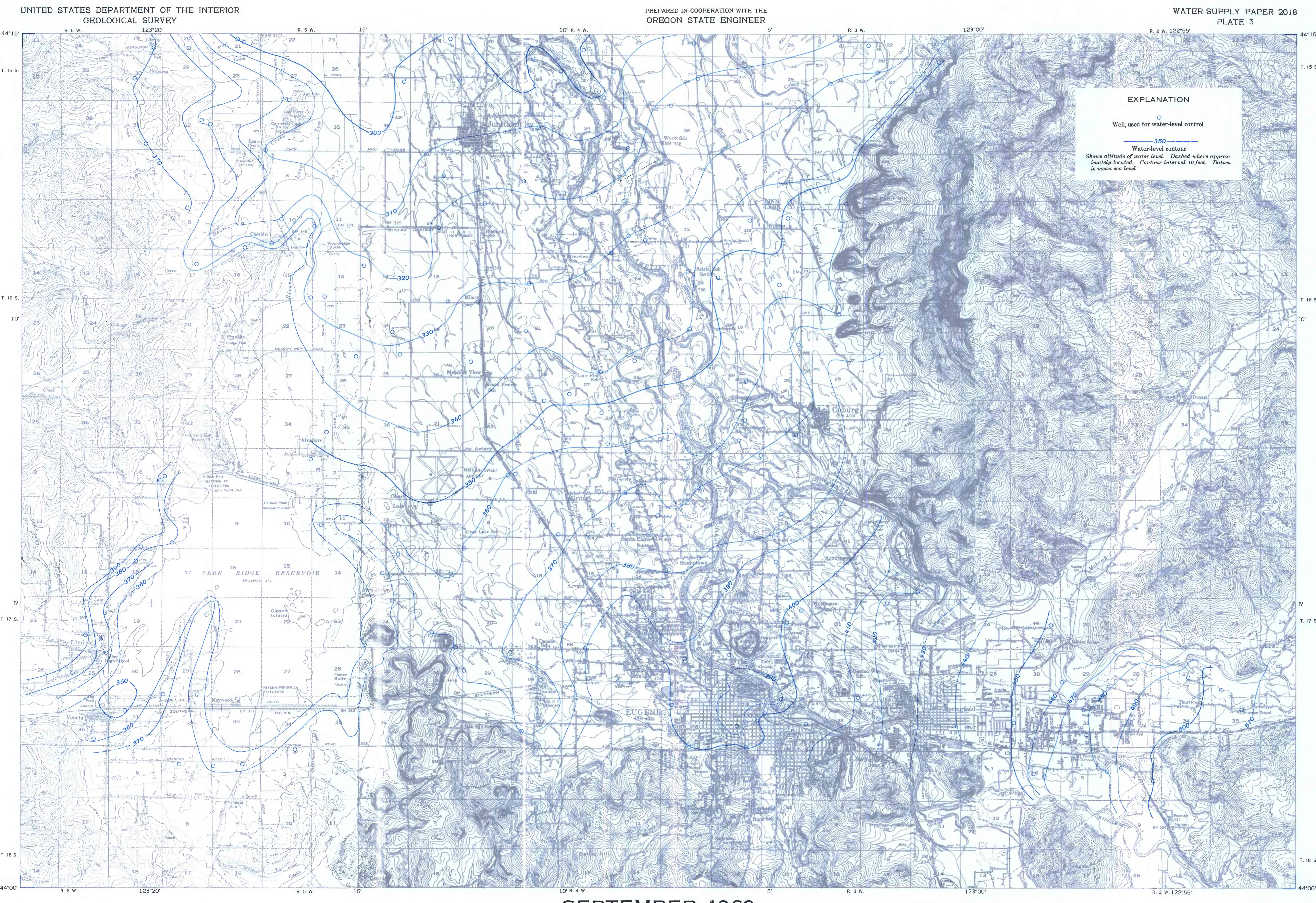
SEPTEMBER 1969

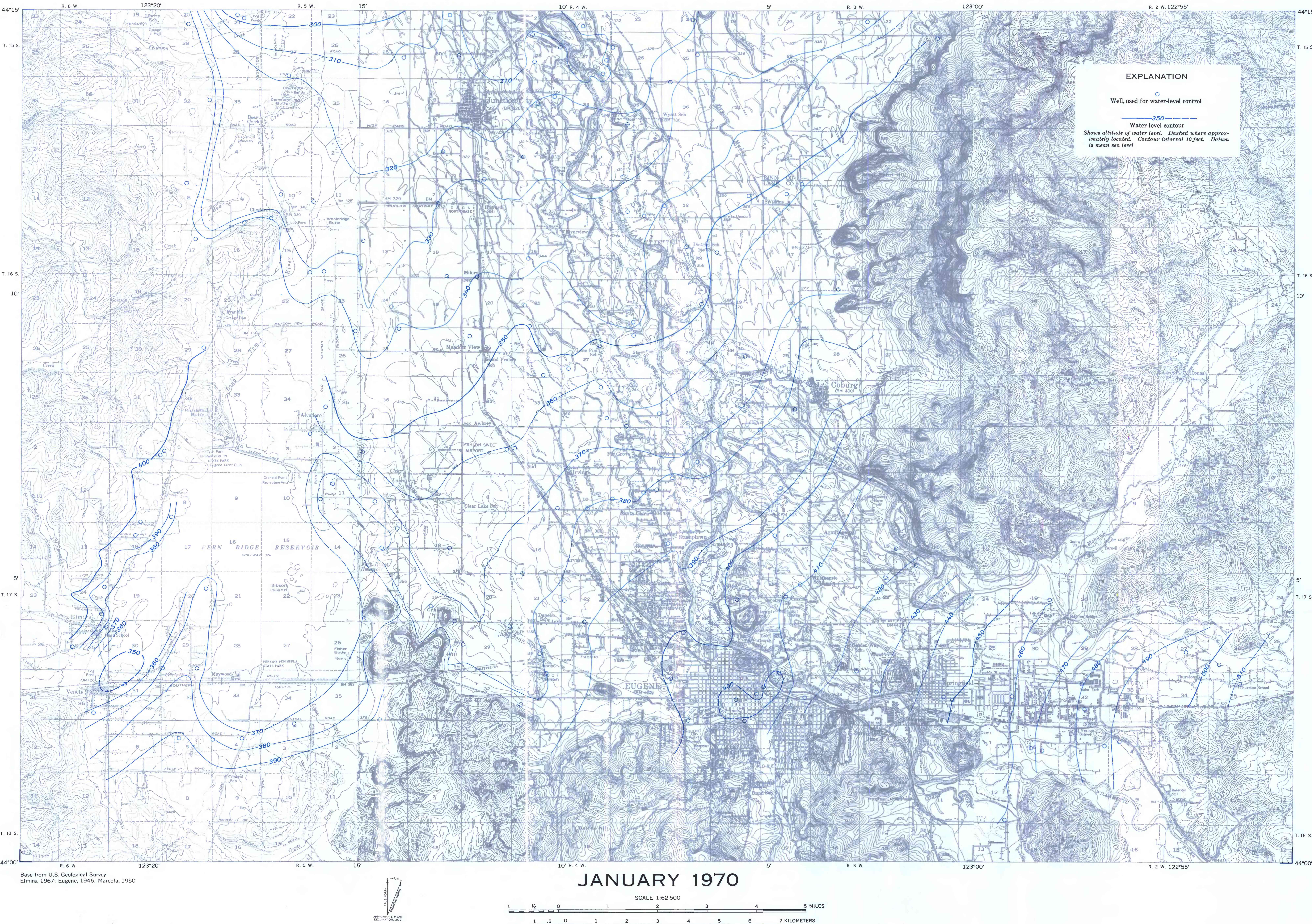

